\title{
第16回日本老年医学会総会一般演題 (I)
}

\section{1. 脳血管障害における交代性片麻㾇に関する研究}

慈恵医大 亀田内科

村田守昭 横山誠之 比嘉康宏 渡辺礼次郎

江沢健一郎

交代性麻瘦は脳幹各レベルでの障害を的確に示唆する特 徵ある症候群であるため, 臨床診断上極めて重要である. 従来から脳血管障害，特に脳卒中に合併することは稀と言 われて来た。私共は今回, 過去 20 年間に本学第 1 内科に て経験した脳卒中発作に随伴した交代性麻㽻 16 例（らち 6例剖検，6例脳血管写施行）につき臨床的ならびに臨床病 理学的に検討，血管障害に由来する交代性麻痺の臨床的特 徵掞よび，その発現様式，成因につき考察し，2３ の知 見を得たので報告する。交代性麻瘦は上交代性麻痺 7 例, Fouille 麻痺 6 例, Millard Gubler 麻疩 1 例, Foville $\rightarrow$ Millard Gubler 麻痺, 及び Millard Gubler $\rightarrow$ Foville 麻痺 各 1 例であり, その原因は出血 4 例, 特発性クモ膜下出血 9 例, 硬塞 3 例である.

過去 20 年間の医学中央雑誌からの集計では，上交代性 麻痺は血管障害 20 例，非血管障害 7 例と血管障害による ものが多い，うち，クモ膜下出血によるものが 11 例をし める。私共の上交代性麻盘 7 例はすべてクモ膜下出血によ るものである，従来からの中脳病変によるWeber 麻瘏と は本質的な相違をみる点注目される。すらわち臨床的には 動眼神経麻瘦と片麻痺発現の時間的ずれをみ, 剖検上, 中 脳には何等の障害なく, 未梢の動眼神経が動脈瘤により種 々の成因で損傷をらけ麻疸を来たし, 他方, 病側の大脳半 球障害（出血, 遅発性軟化）によって対側の片麻疩を来た して居る事実である。

脳橋型交代性麻疩（Foville, Millard Gubler 型）につい ては，以前から血管障害によるものが少ないとされていた が, 過去 20 年の集計では, 55 例中血管障害 36 例に対し 非血管障害 19 例と従来の概念と著しい差異をしめした. これは集計が過去 20 年と限定したため, それ以前に多か った他の原因（結核, 梅毒, 髄膜炎）等によるものが減少 した事が一因と考兄られる。血管障害では原発性脳橋出血 4 例, 脳橋硬塞 3 例, 特発性クモ膜下出血 2 例であり, そ の 3 者で臨床的な差異を認める。すすおち出血病変（4 例 中 3 例剖検一片側被蓋部出血)では意識障害をもって発症, 交代性麻瘏症状の動摇, 何等かの片側性を示寸両側錐体路 症状, 著しい自律神経症状を呈し, 多くは致死的である。 これに対し硬塞病変では意識障害は軽度で, 定型的な交代 性麻痺をしめし, 自律神経症状をしめさず改善傾向がみら れる。

特発性クモ膜下出血によるものは, 臨床例であるが, 原
発性脳僑出血の第 4 脳室穿破症例とは症状経過の上から差 異を認める。明らかなクモ膜下出血発作をもって発症し， 数日後 delayed softening の型で交代性麻痺が形成され， 臨床症状は概して両者の中間的である。

嘼問：沢田 徹〈北里大内科〉

発表の脳幹障害で Foville 症候群を呈した症例のらち, MLF の障害を合併したものがあったか，われわれは最近 脳幹硬塞で Foville 症候群で MLF 下障害を合併したもの を経験している，文献上はこの合併例は少ないのだが，実 際はもっと多い上らに感じているが如何.

答 : 渡辺礼次郎

私共の脳橋部硬塞例は 3 例であり，すべて臨床例であ る. 2 例が Foville 麻盘, 他の 1 例が Millard-Gubler 麻 瘦を呈した。前者は臨床的に MLF の障害が推定される.

\section{2. 老年者における脳血管障害の臨床病理学的研究（第 2} 報）

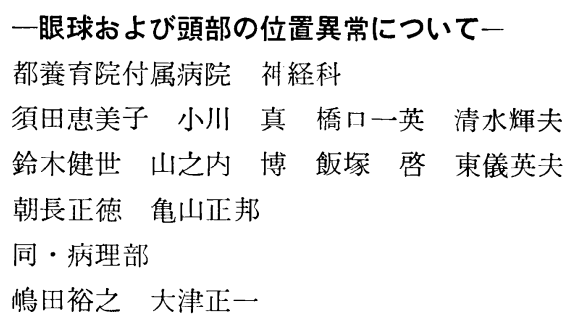

脳病変を有する患者の眼球及び頭部の位置異常は, 局所

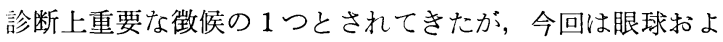
び頭部の位置異常特に共同偏視以外の眼位異常を呈した症 例の臨床症状と病理所見を対比し, 臨床的意義について検 討した.

対象は都盖育院付属病院における約 2 年間の連続剖検 420 例のらち， 60 歳以上で脳血管障害発作の明らかであっ た 148 例とした。

眼位異常を示した症例は出血では 39 例中 19 例(49\%), 硬塞では 109 例中 26 例(29\%) にみられた。 このうち共 同偏視以外の眼位異常は出血では内側型と混合型にみられ 硬塞では主に脳幹部に病変のあるものに多くみられた。

内側型出血では 8 例中 4 例に眼位異常が認められ, 病巣 側へ共同偏視を示したものはわずかに 1 例に過ぎず， 3 例 が共同偏視以外の眼位異常を示した。このらち病巣が視床 内側核に限局し, 脳室内に破れていた症例は, 病巣側の眼 球が内下方位を向いていた。 も5 1 例は病巣側と反対側の 眼球が内下方位を示した。第 3 例は病巣側斜上方への共同 偏視がみられた。

混合型出血では 5 例中 4 例に眼位異常が認められ, 経過 
中いわゆる共同偏視が認められたのは, わずかに 1 例に過 ぎず両眼が内転位をとったものが 3 例，外転位をとったも のが了例であった。脳幹まで病変が波及している症例は 4 例あり,これらの眼位異常と病巣との関係は一定したもの は見出し得なかった。

脳幹部硬塞では共同偏視が少なく眼球運動に関する脳神 経核の破壊によると考えられる複雑な眼位異常を呈した症 例が 3 例あった。 その他両眼球が外転位をとり, 両眼球に 内側縦束症候群が認められた症例は, 主病变は右視床枕に 硬塞巣が存在し，それが中脳上部まで延び，前視蓋部に小 血栓が認めれた。

頭位異常と脳病変については, 出血では 39 例中 15 例 (38\%)に頭位異常がみられ，最も頻度の高かったものは小 脳出訛で 6 例中 5 例にみられ，そのうち 4 例は頭部が病巣 側へ偏向した。硬塞では 109 例中 8 例（7\%）に共同偏祀: が消失した時点で，頭部の偏向が残った。 大脳半球に病変 がみられたのはこれら8例のらち7例で，いずれも中心溝 より前寄りか内包に病変がみられた.

結語 : 大脳型, 脳幹型, 小脳型と言われている眼球およ び頭部の位置異常を呈した症例は多いが，視床，中脳部を 含んだ病変では複雑な眼球位置異常がみられた。

質問 : 荒木五郎〈脳血管研究所, 美原記念病院〉

視床出血で時に病巣と反対例に持続的に共同偏視をみる ことがあるが，視床の障害部位はどこだったか，脳室に穿 破していたか.

\section{答：須田恵美子}

視床病変で病巣側と反対側への共同偏視は 1 例に認めら れたが，病巣が大きいため視床核との関係は不明であっ た.

\section{3. 老人性痴呆様症状を主訴とした硬膜下血腫の 2 例}

東京医大 老年将

柏木和太 沼沢良樹 鶴見信男 小林 肇 勝沼英宇: 種ケ島医院

種帛永宝

老人に打いて進行性に神経症状及び痴呆状態が出現して 来た場合, 脳血栓症あるいは脳軟化症と診断される場合が 多い，我々は，その様な進行性に症状の増強した高齢患者 で硬膜下血腫が, その原因であったと思われ, 内 1 例は外 科的治療を抗こない改善をみた與味ある経験をしたので報 告する。

第 1 例は 70 歳男で昭和 46 年 8 月よりめまい拈よび歩 行障害を主訴として来院し, 脳血栓症の診断で線溶療法を 受けたが, さらに失語, 失計算, 見当識障害がみられる様 になり入院した，入院時上記症状の他に左半身の不全麻痺, 排尿障害を認め, 血圧は 105/80mmHg で一般臨床検査で
は, 血清鉄かi $54 \gamma / \mathrm{d} l$ 以外特に異常所見なく, 骨道液検査で は, 外観 Xanthochronie があり初圧 $220 \mathrm{mmH}_{2} \mathrm{O}$, 終圧 120 $\mathrm{mm} \mathrm{H} \mathrm{H}_{2} \mathrm{O}$, 細胞数 $1 / 3$, 蛋白 $2 / 3$, 糖 $78 \mathrm{mg} / \mathrm{d} l, \mathrm{NaCl} 706$ で あった，眼底は KWI，脳波では右側頭部に除波をみとめ た. CAGにて左中大脳動脈域に Avascular-area あり, 硬 膜下血腫の疑いで, 11 月 8 日脳外科に転科, ボタンホー ル式洗浄手術を行なったところ失語症等の症状の改善をみ 退院した，その後会社重役としての任務をつつがなくこな している.

第 2 例は, 96 歳女で昭和 42 年テレビ観賞中に突然意識 障害, 失禁出現し, 脳軟化症の診断にて近医の治療を受け 改善している. 昭和 47 年 4 月再び同様症状を呈しこの項 より失見当識, 記銘力低下, 異常行動が見られる様になり, 昭和 48 年 9 月 11 日尿毒症で死亡した. 本例は生前充分な 検査を行ない得なかったが，頭部単純 X-P にて右頭頂部 に石灰化像を認め, 血清化学検查にて死亡直前に血清総蛋 白の低下, 総コレステロールの低下及び尿素窒素の上昇が 見られた。剖検にて右前頭部から側頭にかけての大きな硬 膜下血腫を認めた。

以上の 2 例は共に外傷の既往なく, 第 1 例は右不全麻 痺，第 2 例は右三叉神経痛の既往歴がある以外巣症状はな い. 精神症状は第 1 例は健忘症状が主で, 第 2 例は異常行 動が主として認められた。診断は第 1 例は CAG にて，第 2 例は生前に診断できず, 剖検にて確認された。血腫の位 置は, 第 1 例は左側頭部よりやや前方にかけてあり, 第 2 例は右前頭部より側頭部にかけてであり，共に前頭葉に圧 迫が加えられている点から，これらの症例の精神症状に対 し硬膜下血腫が何らかの影響を与えた事は明らかである。 少なくとも第 1 例においては, 脳外科的処置にて症状の改 善がみられる点から, 硬膜下血腫が原因であると言えよ 5 .

高秢者に批いては, ややもすると各種の精神症状を，老 人性痴呆脳動脈硬化症として診断しがちであるが，なかに はこの様な症例もあり, この場合全身状態が許せば, 外科 的に治療する事のできるものであり，また最近頻繁に使わ れ始めた抗疑固療法は, 禁忌である点, 心すべきと思われ る.

\section{4. 老年者にみられる失語症状の特徵}

都養育院付属病院 言語恥覚㡣療科 福迫陽子 物井寿子

都老人総令研究所言語聴覚研究室 綿森淑子 笹沼澄子

失語症は成人にみられる言語障害の中で最も頻度が高い ものの 1 つであるが，失語症状と加齢との関連については ほとんど知られていない，我々は，老年者における失語症 状の特徵を調べることを目的に老年者と壮年者の失語症患 
$12: 76$

者の言語症状を比較した。

対象は, 昭和 47 年 6 月 49 年 8 月に東京都養育院付 属病院言語聴覚診療科を受診した 51 例の失語症患者であ る。年齢は 38〜24 歳にわたり，65 歳以上 36 例（以下老 年群), 60 歳未満 15 例（以下壮年群）であった。病因は 壮年群の頭部外傷 2 例を除き全例が脳血管障害であった。 発症からの経過期間は， 1 例を除き（ 8 年） 1 力月 3 年 7 カ月で, 1 年未満 37 例 $(72.5 \%)$ であり, 両群とも同 様の傾向を示した。検査は, Schuell 笹沼失語症鑑別診断 検査（老人研究所版）を用いた。

まず，検査を完全に実施できたものは，老年群では 36 例中 19 例（52.7\%）にとどまったが，これに対し壮年群 では 15 例全例が可能であった。この差は $1 \%$ 水準で有意 であり，老年群では壮年群に比べ検査を完全に実施できる 例が少ないといえる。

失語症検查を実施できた 34 例の重症度は, 両群ともか なりバラッキが大きかったが, 老年群では, 重症例が壮年 群よりも有意に多く認められた。

失語症のタイプについては, 老年群でも壮年群と同樣に さまざまなタイプの失語症が認められるが, 全失語の出現 率が高い傾向がみられた。

言語治療をうけたものは，老年群では 36 例中 22 例 (61.1 \%), 壮年群では 15 例中 14 例 (93.3\%) であり，老年群て は言語治療をうけたものが有意に少なかった，なお，老年 群で言語治療をうけたものが検査を完全に実施した例数よ りも多いことは，診断的治療をうけた症例（3 例）も含ま れているためである．治療効果は，治療開始後 3 力月末満 の 3 例を除く 28 例について判定した. 改善（ここでは鑑 別診断検査に打ける得点の变化または実用場面に扣ける改 善を意味する) が認められたものは，老年群では 6 例(35. $3 \%)$ であるのに対し， 壮年群では 9 例 $(88.8 \%)$ であっ た。この差は統計的にも有意で，老年群では改善例が有意 に少なかった。

以上まとめると，老年者の失語症の特徵としては，重症 例が多く, 言語治療の適応打よび効果の認められる例が少 ないことがあげられる。この理由としては，脳の老化と， これに加兄て原因疾患そのものが重症な場合や, 合併症が 多いことなどが考えられる。しかし，老年者失語症患者の 約半数には言語治療の適応があり，さらにその $1 / 3$ に改善 が認められることは，老年者のリハビリテーションを考慮 する際に注目すべきことと思われる。

質問 : 竹田契一〈伊豆菲山温泉病院〉

「訓練効果があった」とはどらいう意味か。

\section{答 : 福迫陽子}

言語治療の効果を, 何でみるのが妥当であるかは, 確か に問題のあるとこである。今回は，失語症鑑別診断検査に 淤ける得点の变化と, 言語の実用場面に拈ける改善を, 判
12巻 2 号（1975:3）

断の資料とした.

\section{5. 失語症実態調査結果について}

伊豆菲山温泉病院

竹田契一 長谷川恒雄

昭和 45 年度に引き続き，第 2 回失語症実態調査を行な った，主な調査内容は，失語症患者数，失語症患者が全脑 損傷患者に占める割合，失語症の原因疾患，言語訓練の実 態, 社会復㷌の内容などである。

調査方法は，郵送によるアンケート方式を採用し，一部 は電話連絡によった。対象施設は，リハビリテーション専 門施設, 国・公立総合病院, 大学附属病院, 200 㦿以上の 私立病院扣よび関連学会に会員のいる病院などである。 ンケートは 784 施設に発送され，297施設より回答があっ た，回収率は $37.9 \%$ であった。そのらち，何らかの記載 のあった 202 施設をまとめの対象とした。

調查結果 :

（1）脳損傷患者数と失語症患者の割合

回答のあった 179 施設における入院，外来の脳損傷患者 総数は， 147,779 人そのうち失語症は 3,818 人で約 $26 \%$ を占める。

（2）リハビリ専門施設（10病院）で失語症の占める割合 は較比的高く，脳損傷患者総数 $9.2 \%$ であった。

(3) 失語症の原因疾患別人数.

3419 人のらち脳卒中が多く 2460 人 $72 \%$ ，全体の $3 / 4$ を占める。脳外傷は $13.3 \% 454$ 人，脳腫瘍は $11.9 \%$, 408 人であった（リ八専門病院では脳卒中が $90.8 \%$ )

（4）脳損傷全体の原因疾患別人数

脳卒中 $45.1 \%, 13,135$ 人で一番多く，脳外傷 33.4 $\%, 9,847$ 人と続く.

（5）失語症を除く脳損傷による言語障害の種類別人数.

回答のあった 153 施設において 3,662 人の言語障害者 が怙り，そのらちマヒ性構音障害が $61.7 \%$, 音声障害 5.6 $\%$, 吃音, 構音失行などのその他に属するものが $4.5 \%$ で あった。

（なおリ八専門病院では，マヒ性構音障害が $96.3 \%)$

（6）失語症に対する言語訓練の現状

回答のあった 192 施設のらち言語訓練を行なっている施 設は 108 施設， $56.3 \%$ であった。そそのうち系統的に言語 訓練を行なっているのは 50 施設 $46.3 \%$ のみであり, 全 体の $26 \%$ にあたる.

(7) 言語訓練の専従者およびその学歷

専従者のいる施設は 42 施設で全体の $20.8 \%$, 学歴では 42 施設, 115 人の専従者のらち 4 年制大学卒以上が 77 人, 67\% であった。

（8）言語治療士としての教育をどこで受けたか.

国立聴力言語障害センター短期研修，同附属聴能言語専 
門職員養成所での 1 力年研修, 全国労災事業団短期研修, 病院研修，海外留学などである。

(9) 社会復帰の現状

回答のあった 57 施設において，1,281 人の失語症患者 のらち職場復㷌したのが 230 人，18\%，このらち原職復帰 が 98 人， $7.7 \%$, 配置転換が 60 人 $4.7 \%$, 再就職が 46 人, $3.6 \%$ であった.

以上の調査に貴重なデータを提供くださった 202 施設の 諸先生方に厚く御礼申し上げます。

\section{6. 追跡調查からみた「脳動脈硬化性精神障害}

慈恵医大 精神・神経科

新貝憲利 中村吉伸 岡井平太 新福尚武

追跡調查から見た「脳動脈硬化性精神障害」104 例, 回 収率 $60.11 \%, 1$ 年から最高 13 年平均 3.5 年の追跭調查の 結果を発表する. 年路別 40 歳 49 歳 6 例, 50 歳 $５ 9$ 歳 36 例, 60 歳 69 歳 33 例, 70 歳 79 歳 24 例, 80 歳 $\sim 89$ 歳 5 例, これらを神経衰弱型, そうらつ型, 幻覚妄想型, 疾 呆型（以下それぞれ $\mathrm{N}$ 型, $\mathrm{MD}$ 型, $\mathrm{P}$ 型, $\mathrm{D}$ 型に略す。）に 分類.これらの病型の経過について, N型 45 例の経過は 無症状のもの 15 例, なお $\mathrm{N}$ 型であるもの 19 例, $\mathrm{MD}$ 型 1 例, $\mathrm{P}$ 型 1 例, $\mathrm{D}$ 型 8 例, 死亡 1 例. MD 型 28 例の経 過は, 無症状のもの 15 例， N型には 2 例，なお $\mathrm{MD}$ 型 であるもの 2 例，痴呆型には 6 例，死亡 3 例， $\mathrm{P}$ 型 8 例の 経過は, 無症状 1 例, $\mathrm{N}$ 型 3 例, 痴呆型 2 例, 死亡 2 例. D型 23 例の経過は, 無症状 1 例， N型に 1 例，現在なお D型のもの 14 例, 死亡 7 例であった。現在無症状の 32 例は $\mathrm{N}$ 型 15 例， $\mathrm{MD}$ 型 15 例， $\mathrm{P}$ 型 1 例， $\mathrm{D}$ 型 1 例であ るが，この D 型のは誤診であろう。また，4 年以上の追跡 からみてみると 32 例中 14 例がその中に入る。この 14 例 は大半が $\mathrm{N}, \mathrm{MD}$ 型で占められておりこれらの型は血管性 のものではなかったと思われる。また，暫定診断と確定診 断の異なったものは 38 例でその中に MDI 14 例, Neurose 9 例であり, HAS ではN型, MD 型が特に誤診率が高い と思われる。 D型 23 例中 7 例が卒中死であり病型の変化 がなくな和D型の 14 例は約 $80 \%$ が症状増悪の傾向が あり D型に打いては $\mathrm{P}$ 型同様診断は正しかった様に思われ る，以上より診断が疑わしいと思われるのは全体の $31 \%$ と高值を示している。また，明らかに他の病型に移行した と思わ就るのは $\mathrm{P}$ 型 $62.5 \%, \mathrm{MD}$ 型 $28.6 \%, \mathrm{~N}$ 型 22.2 \%, D型 $4.3 \%$ であった。これらのD型， MD 型， $\mathrm{N}$ 型 の中でD型に移行したのは $10 \%$ と高く, 最も移行しにく いのは，D型 (98.7\%) であるところから HAS の病型は 移行するものであり最後にはD型で固定すると云う事を示 しているものと思われる，次に治療に対する反応は，治療 効果があまりなく初診時とあまり变化しなかったものおよ び徐々に悪化していったものそして死亡したものは次の通
りである。

$\begin{array}{lccc}\mathrm{N} \text { 型 } & 45 \text { 例中 } & 15 \text { 例 }(33.3 \%) \\ \mathrm{MD} \text { 型 } & 28 \text { 例中 } & 6 \text { 例 }(21.4 \%) \\ \mathrm{P} \text { 型 } & 8 \text { 例中 } & 3 \text { 例 }(37.5 \%) \\ \mathrm{D} \text { 型 } & 23 \text { 例中 } & 18 \text { 例 }(78.3 \%) \text { であった. }\end{array}$

これにょり $\mathrm{D}$ 型では他型より王倒的に多く治療に対して は反応しにくい事を示している。

また以前卒中発作があったもので卒中時には来院してい ないもの括よび経過中に卒中発作を起こしたものは 12 例 （11.5\%）でD型に多く，治療には反応しにくく症状が悪 化したもの死亡したものは $15 \%$ であった。病型の移行は あまり見られなかった。死亡したものは 1 例と少なかっ た．卒中発作既往のものは治療には反応しにくく改善傾向 は少ない事を示した。

\section{7. 加齢および血管障害による脸血流の \\ 流速脈波パターンの变化}

阪大 精神神経科

稲岡 長 金子仁郎 白石純三 奥田純一郎

関山正彦 金田平夫 近藤秀樹 門田永治

超音波ドップラー法による内頸椎骨動脈の流速脈波パタ ーンが，加齢および血管障害でどの様に変化するかを検討 した. 対象は 20,30 歳台の健常若年群 47 例（平均 26,7 歳） 40,50 歳台の健常中年群 38 例（平均 49.7 歳） 60 , 70 歳台の健常老年群 54 例 (平均 68.4 歳) の計 139 例 と，障害血管群として V.A.G. により椎骨動脈に閉塞性 の病変が確められた 13 例（平均 49.1 歳）の 4 群である.

内頸動脈については， $\mathrm{S}_{1}, \mathrm{~d}$ は加齢に伴って直線的に有 意に低下した． $\mathrm{S}_{2}$ は加秢による変化は認められない，I.D は低下寸るが有意ではない，心収縮期初期峰 $\mathrm{S}_{1}$ のたち上り の角 $\theta\left(\tan \theta=\mathrm{S}_{1}-\mathrm{d} / \mathrm{lS}_{1}\right)$ は加㱓に伴い有意に小となった. $\theta$ は平均值が若年群で $64^{\circ}$, 老年群で $51^{\circ}$ であった, $\mathrm{S}_{1} / \mathrm{S}_{2}$, $\mathrm{d} / \mathrm{S}_{2}$ の加秢による低下も有意であった。椎骨動脈について もほぼ同様の結果を得たが，椎骨動脈の特徵としては，流 速が遅いせいか若年群から中年群にかけて上述の各価が著 明に低下寸るが，中年から老年にかけては有意の変化がな い.また, $d / S_{2}$ が低下を示さないのも椎骨動脈の特徵であ る.すなわち, 流速脈波パターンは加龄に伴って, 心収縮 期初期峰 $\mathrm{S}_{1}$ がたんだん低下し, 収縮期第 2 峰 $\mathrm{S}_{2}$ との比が 小さくなって，老年では $\mathrm{S}_{1}$ と $\mathrm{S}_{2}$ の高さが同等もしくは逆 転する。ささらに初斯峰のたち上り角 $\theta$ も小さくなり，なだ らかに上昇する。一方，心抁張期では， $\mathrm{d}$ が低下し波形が 断続的になる事がわかった．障害血管群では年㱓構成が健 常中年群とほぼ同じであるにもかかわらず，各 indicator は老年群よりも更に低值を示している，以上の様な波形の 加㱓に上る变化は，ビニールチューブにデキストリン容液 を人工心肺用ポンプで流し抵抗を徐々に增した場合の波形 の変化とよく一致した， 
また，流速脈波曲線をサウンドスペクトログラフ上, 6.6 $\mathrm{mm}$ 時間にして 0.6 秒で揃光， 5 次までフーリエ解析を行 なったが, 内頸・椎骨動脈流速脈波曲線共に $\mathrm{C}_{1}$ の上昇と $\mathrm{C}_{2}, \mathrm{C}_{4}$ の減少が有意であった。ささらにこれら高次の項を $\mathrm{C}_{1}$ に対する割合としてみると，加齥により高次の項のしめる 割合が減少していくことが明確になった。つまり老年者の 流速脈波は大きいら㸚りの成分がほとんどで，それに重量 する小さい波の成分が少なくなることを意味する，他方， 脳血管障害群のフーリエ解析の結果は特異であり， $\mathrm{C}_{2}, \mathrm{C}_{4}$, $\mathrm{C}_{5}$ は若年から老年に至る变化の傾向とは全く異質である. $\mathrm{C}_{1}, \mathrm{C}_{2}, \mathrm{C}_{4}$ の価自体もかなりかけ離れた価を示した。これ は血管障害が，単なる加秢の延長ではなく，何らかの別の 変化が起きていることを示唆するものと思われる。

\section{8. 脳功脈硬化の定量診断（圧・流連ヒステリシス法によ る脸血流インピーダンス測定）}

大阪市立弘済院病院 内科

宮崎 学

[方法]

実験対象は健康青年 5 例, 健康中年 $(40 \sim 50$ 歳台の健康 者） 6 例, 脳血管障害例（70 歳以上の高度脳動脈硬化ない し脳卒中後遺症例） 6 例の合計 17 例である.

実験力法としては，超音波ドップラー法によって内頸動 脈血流速度波波形，また圧脈波計によって総頸動脈圧脈波 波形をそれぞれ同時かつ連続的にオッシログラフおよで磁 気テープに記録した，次に XYレコーダーにおいて，脳血 流波パターン扣よび脳圧脈波パターンから一心拍毎の Lissajous figure を作製し，これより脳血流インピーダンス （最大流速時の血圧/流速比）を算定した。一方, calibration に関連して, 脳血流波パターンの最高振幅值と脳生脈波パ ターンのそれとが同等を示す条件下で本ィンピーダンスを 測定した。

[成績および考察]

（1）各群の脳血流インピーダンスを比較すると, 健康青 年 $0.618 \pm 0.019$, 健康中年 $0.747 \pm 0.112$, 脳血管障害例 $0.970 \pm 0.069$ であり，かつ健康青年と脳血管障害例との 間には有意差を認めた $(\mathrm{p}<0.01)$. すなわち, 脳血管抵抗 は健康青年が最小, 脳血管障害例が最大, 中年例は両者の 中間を示した。

(2) 脳血流波パターンの最高振幅值と脳圧脈波パターン のそれとが暴なる場合の脳血流インピーダンスを検討した ところ, 本インピーダンスは, 両パターン振幅值の変化に 対応して変動した. 一般に, 脳血流インピーダンスは, 脳 血流波パターン振幅值とは負相関, また脳圧脈波パターン 振幅值とは正相関を示す。すなわち，本インピーダンス測 定の calibration に関しては，両パターン最高振幅值が同 等であることが基本的要諦といえる.
（3）昇生負荷（ノルアドレナリン投与）に打ける脳血流 インピーダンスの推移を検討すると, 著しい血圧上昇に伴 なって本インピーダンスは若干の変化（上昇ないし低下） を示した. すなわち, 脳血流インピーダンス測定にさいし ては，著しい血圧変動の影響を充分考責に入れる必要があ る.

以上, 2,3 の付帯条項を勘案する場合には, 脳血流イン ピーダンス測定法は, 脳血管抵抗ひいては脳動脈硬化の定 量診断法として有用と考える.

\section{質問 : 白石純三〈阪大神経科〉}

Inl管でインピーダンスを求めるには一般に生脈波と容積 脈波を Fourier 解折し各 harmonicsについて計算してい るが,

(1) 流速脈波をそのまま容積脈波と考えてもよいか?

(2) 先生のインピーダンスの計算はどの様にされたの か?

\section{答 : 宮崎 学}

本実験では, 脳血管抵抗（脳血流インピーダンス）を反 映する指標として, 止流速ヒステリシスから算出される最 大流速時の血圧／流速比を用いている．本法の妥当性を裏 付ける意味において，さらにインピーダンスの周波数ない し位相特性についても比較, 検討したいと考学ている.

\section{9. 老年者（60 歳以上）における脳血管写 一診断的意義と合併症一}

都養育院付属病院 神経科

橋口一英 小川真 清水輝夫 渡辺進馬 須田恵美子 飯塚 啓 山之内博 東儀英夫 朝長正徳 亀山正邦

同 核医学放射線部

山田英夫 遠藤和夫

老年神経患者においてもその診断, 治療に際し脳血管写 が必要不可欠の場合は少なくないが，一般に老年者では動 脈硬化の存在, 全身的抵抗力の低下等によりその実施に際 し若年者より注意すべきであると考えられている。この報 告の目的は 60 歳以上の老年者における脳血管写の診断的 意義と合併症について我々の経験例をもとに検討し老秢と いら事が脳血管写に際し如何なる危険因子となり得るかを 明らかにする事である。

対象：当病院入院患者で昭和 48 年 4 月より約 1 年間に 施行した 60 歳以上の男 59 例, 女 57 例計 116 例に対し 行なった 169 回の脳血管写である.

方法：前処置は原則として硫酸アトロピン $0.5 \mathrm{mg}, 10 \%$ フェノバール $1 \mathrm{~m} l$ を施行前 30 分に㳙注した。造影剂は $60 \%$ コンレイを使用した。針はテンロン針又はディスポ ザブルの針を用いた，穿刺部位は CAG の際は総頸動脈, VAG の際は上腕動脈より逆行性に撮影した.

結果 : 脳血管写でえられた異常所見として脳血管閉塞 
22 例, 脳出血 4 例, 硬膜下血腫 5 例, 脳腫瘍 5 例, 動脈 瘤 8 例, 両内頸動脈久損 1 例, 動脈硬化や狭窄 40 例であ った．脳出血また脳硬塞と診断した 80 例では 24 例(30.0 \%)に臨床診断を支持する所見がえられた。 それに硬膜下 血腫, 脳腫瘍, 両内頸動脈欠損が各々 1 例, 閉塞は認めな いが動脈硬化や狭窄が 27 例に認められた。剖検所見と比 較しえた 24 例で, 脳動脈閉塞 5 例, 脳出血 4 例, 硬膜下 血腫 2 例, 脳腫瘍 2 例の血管写による診断は剖検所見と一 致した。挐管写上動脈硬化や狭害のみ認めた 9 例中 4 例に $1 \mathrm{~cm}^{2}$ 以上の硬塞巣, 3 例に小硬塞巣が剖検により認めら れた。血管写上異常なかった 4 例にも $1 \mathrm{~cm}^{2}$ 以上の硬塞巣. が 2 例, 小硬塞巣が 1 例認められた。

合併症：CAG を行った 111 回のうち 30 回 (27.0\%)に 合併症を認めた。 その症状は意識低下 (9 例) 発熱(16例). 血圧低下, 血圧上昇, 呼吸障害, 言語障害, 白血球增加, 皮疹等で，すべて一過性であった。合併症は 80 歳以上の 症例, 両側 $\mathrm{CAG}$ 施行例, VAG より $\mathrm{CAG}$ に多く, 造影 剤の量が多い程頻度も高く，患者の意識状態，糖尿病の有 無, 動脈硬化の程度等とは関係がなかった。技術的な合併 症としては穿刺部位の血腫等認めたが，血腫による呼吸䧛 害は両側 CAGの 1 例のみで外科的処置は必要としなかっ た．前処置に steroid 剤を使用する事により合併例は減少 した。老年神経患者の脳血管写は注意深く施行すれば従来 いわれている程重篤な合併症は少なく, steroid 剂を前処 置とし使用する事によりさらに減少さす事ができ, 診断, 治療に際し有益な情報源となりえる為, 老年者の脸血管障 害, 硬膜下血腫, 脑腫瘍等の確定診断には必要不可欠であ る.

質問 : 田崎義昭〈北里大内科〉

80 歳以上の脳血管写の適応をどう考觉るか.

答 : 亀山正邦

卹管撮影時の合併症は, 個々のものはいずれも軽度では あるが，その頻度は，必ずしも少なくない，やはり，症例 を選んで慎重に行ならべきであると考える。

質問 : 伊藤栄一〈国立名古屋病院〉

発症より脳血管写を施行するまでの期間によって副作用 の頻度はかわるか.

質問 : 沓沢尚之〈秋田脳研〉

ステロイドを血管写実施前に使っておられるが，その目 的は？またどの程度の量を使っておられるか?

答 : 橋口一英

(1) 脳血管障害発作時より CAG 施行までの期間で副作 用の頻度に差を認めなかった。

(2) steroid 剂は経験的に使用し，有効である事を認め た. steroid 剤は術前 30 分に Hydrocortisone を $100 \mathrm{mg}$ 筋注した。

(3) 80 歳以上の CAG は副作用の頻度も高く case by case で慎重に行らべきだと思う。

\section{0. 老年核医学の臨床 (7)}

\section{高齢者脳血管障害における脳シンチグラフイの評価}

都養育院付属病院 核医学放射線部

阿部正秀 飯尾正宏 千葉一夫 村由 啓 松井謙啠 山田英夫 布施正明

脳血管障害の多い高龄者の脳疾患スクリーニングとして 脳シンチグラフィ法は有用なものである。今回剖検および 手術例を中心に老年者の脳シンチグラフィ法の価值を検討 し報告する。対象：過去 2 年 2 カ月間に脳スキャンを行っ た 60 歳以上の 402 症例中, 剖検例 77 例, 手術例 13 例 を中心に検討した。 方法： ${ }^{99} \mathrm{~m} \mathrm{Tc} 0_{4}^{-}$または ${ }^{99} \mathrm{~m} \mathrm{Tc}$ ピロリ ン酸を静注後, 前者は数十分後, 後者は $2 \sim 3$ 時間後上り スキャンした。

のベ病巣数 103 の内，脳血管障害 49, 脳腫瘍 21 , 硬膜卜 出血 9 などで，脳血管障害が過半を占めた。脳血管障害例 においてシンチグラム上 49 病巣の内, 確実に異常を認めた のは 16 (32.7\%), 不確実であるが異常のあるもの 5 (10. $2 \%)$, 全く正常であったもの 28(57.1\%) であった。脳血 管障害を大さく脳実質内出血之脳硬塞に分けると, 前者 11 , 後者 39 病巣中, シンチグラムで異常を指摘できたのは 36. 4\%，33.4\% と大差なかった。病巣の大きさとシンチ グラム所見を比較すると小又は散在性の病巣群 (A) では出 血，硬塞共に全く異常は指摘できず，限局性病巣群(B)では 硬塞 53\%, 出血 0 であり, 病巣がより大きくなると (C), 出血 $80 \%$, 硬塞 $66.6 \%$ と確診率も高くなった。脳血管障 害例において発症の明確な例におけるスキャン所見と時間 経過は $(\mathrm{B})(\mathrm{C})$ 群において, 発症後 4 日以内又は 2 力月以後 ではシンチグラム上異常を認める事は少なかった。最も早 い症例で発症後 6 日目のスキャンで陽性像を呈し, 最も長 い例では280日もの長期に渡り陽性像を呈した一例もあっ た。この症例は途中明確な再発作は認められなかった。一 方小または散在性の病巣群 (A) ではすべて陰性のシンチグ ラムを得た。すなわち脳腫瘍に比し CVA のシンチグラム に陰性例の多いのは病巣の形扐よび発症後診断までの経過 によるもので，適当な時期にスキャンを行なえば高率に病 巣部位と拡がりを指摘しらるのである。シンチグラムで $\mathrm{C}$ VA の重症度を診断しらるかどらかをみるためにシンチグ ラム読影上, 上矢状静脈洞と病巣の濃度を比較し $0 \sim \mathrm{N}$ 度 に分類した。発症後早期に III, $\mathbb{V}$ 度であるもの程予後があ まり良くない傾向が見られたが， III，II度の状態で 280 日 もの長期間途中明確な再発作を認めず陽性所見を続けた例 も認められた。 III, IV 度の例でもシンチグラム上急速に改 善された例は臨床症状も比較的改善されやすい傾向も認め られ，脳スキャンよりある程度予後を推定できると思われ た，老人では脳血管障害と共に脳腫瘍も多く，その発育が 
遅い傾向も認められる。また脳血管障害の診断下に隠され た脳腫瘍も多く, その鑑別は重要である.我々は ${ }^{99 \mathrm{~m}} \mathrm{Tc} 0_{4}^{-}$ス キャンに加し ${ }^{99} \mathrm{~m} \mathrm{~T} c$ ピロリン酸スキャンを行ない良い成績 を得心.ピロリン酸は腫瘍例に打いて全例陽性像を呈し, 血管障害例ではまれにしか陽性とならない事と共に血管障 害でも比較的脳硬塞例で陽性となる事が認められる。両者 を用い鑑別診断がある程度可能と思われた。

質問：田崎義昭〈北里大内科〉

脳硬塞で陽性シンチグラムが長期持続するものがあると のことであるが，剖検所見はどうであったか.

答 : 阿部正秀

1. 脳血管障害例でシンチグラム上異常に長期間陽性像 を呈する例は, 潜在的な再発作がある事も考えられる。し かし剖検上その変化は明確には証明された例はなかった。

\section{1. 老年者における脳の血管病変に関する研究（第 2 報） 内頸動脈, 外頸動脈分岐部における石灰化について 都養育院附属病院 神経科 \\ 山之内博 橋口一英 渡辺進馬 清水輝夫 小川 真 須田恵美子 飯塚 啓 東儀英夫 朝長正德 \\ 亀山正邦}

剖検材料による内頸動脈，外頸動脈分岐部（以下分岐部 之省略）の石灰化汇関する研究は少ない。この報告の目的 は分岐部石灰化々頭蓋内動脈の狭窄度, 脳の血管性病変と の相互関係を検討し, 脳血管性障害に括ける上記動脈石灰 化の意義を考察する事にある。

対象並方法：60 歳以上の剖検例より無作為撰択した男 女, 各 50 例, 計 100 例で年代別では 60 歳代 9 例, 70 歳 代 46 例， 80 歳以上 45 例である。剖検時分岐部を含め て総頸動脈, 内・外頸動脈を周囲の組織より分離, 切断し 超軟 $\mathrm{X}$ 線撮影を施行した。

石灰化の程度はX線像上り点状, 塊状, 大塊状石灰化に 分類し，塊状石灰化以上を高度石灰とした。

結果：1）分岐部石灰化は全例の 58\% にみられ，5ち 高度石灰化は $42 \%$ にみられた。年代別有石灰化の頻度は 60 藏代 $55.6 \%, 70$ 歳代 $56.5 \%, 80$ 歳以上 $60.0 \%$ であっ た．分岐部石灰化は男女で差が認められなかった。分岐部 石灰化は内頸動脈側に強い場合が多かった．2）前および 中大脳動脈の狭窄度と分岐部石灰化の程度を刘比検討する と, $50 \%$ 以上の狭窄は有石灰化群, 高度石灰化群任有急 の高率で認められた．3）前扣よび中大脳動脈支配領域の 血管性病変と分岐部石灰化との対比検討では肉眼的に脳に 血管性病変を認めなかった 30 例中 21 例（70\%）は分岐 部石灰化のない例であり, 中小の硬塞は皮質, 皮質下なら びに基底核・内包それぞれに拈いて有石灰化群, 高度石灰 化群に有意の高率で認められた。大硬塞では差が認められ ず，高血圧性脳出血は高度石灰化群に多い傾向が みられ
た.

4）分岐部石灰化は高血圧群に有意の高率でみられたが 総コレステロール值とは有意の関係はみられなかった。

5）分岐部石灰化の生前に括けるX線像での検出率は点 状石灰化 $15.4 \%$, 高度石灰化 $71.9 \%$ であった。

結論：1） 内頸動脈 - 外頸動脈分岐部石灰化の高度の群に 頭蓋内動脈の狭窄が強い場合が多い，2）分岐部石灰化の 強い群に中小の脳硬塞を認める場合が多い，3） 分岐部の 塊状または大塊状石灰化の約 $70 \%$ は生前のX線像で検出 された。

質問：田崎義昭〈北里大内科〉

超軟 $\mathrm{X}$ 線所見が同じでも, 普通 $\mathrm{X}$ 線で石灰化があったも のと, なかったものとで, 脳の病理所見に差異はあった か.

\section{答 : 山之内 博}

超軟 X線像による点状石灰化と塊状石灰化の病理組織学 的差異の有無については現在検索中である.

\section{2. 老年脳疾患の脳循環調節（第 1 報）}

北里大 内科

大坂 彰 田崎義昭 沢田 徹 古橋紀久 衣川秀一 目的 : 脳循環調節に括ける神経因子の関与は, 近年, に わかに注目を集めているが, 老年者に抢ける脳循環の自己 調節障害に関する詳細な検討は少ない，そこで，われわれ は, 脳血管障害を主とする高路者脳疾患例について脳循環 の自己調節機序ならびに $\mathrm{CO}_{2}$ 反応性を検討した。

方法 : 対象は内頸動脈系脳血管障害 24 例（うち急性例 6 例), 脳幹部硬塞 9 例, 仮性球麻瘒 5 例, 脳幹変性疾患 6 例の計 44 例である.

その各々に $60^{\circ}$ 頭部举上 5 分間扣上び $5 \% \mathrm{CO}_{2}$ 吸入 3 分間を負荷し, 負荷前および負荷中の脳循環を測定した. 脳血流量 $(\mathrm{CBF})$ は $\mathrm{N}_{2} \mathrm{O}$ 法を用いて測定し, 脳循環の自 己調節および $\mathrm{CO}_{2}$ 反応性の指標としてそれぞれ $\triangle \mathrm{CBF} /$ $\triangle \mathrm{MABP} ， \triangle \mathrm{CBF} / \triangle \mathrm{PaCO}_{2}$ を用いた。

結果 : (1) $60^{\circ}$ 頭部挙上により脳灌流血圧の下降 (平均 15 $\mathrm{mmHg}$ ) とともに, 内頸動脈系脳血管障害急性例および広 範脳幹硬塞例飞打いて高度の $\mathrm{CBF}$ の減少を認め, $\triangle \mathrm{CBF} /$ $\triangle \mathrm{MABP}$ はそれぞれ $0.36,0.52$ と高値を示していた。こ れ飞対して内頸動脈系脳血害障害慢性例, 限局性脳幹部硬 塞および仮性球麻痺例に扣いては, 頭部挙上に上り脳灌流 血圧が低下しても， $\mathrm{CBF}$ の変化は少なく $\triangle \mathrm{CBF} / \triangle \mathrm{MABP}$ は $0.15,0.06$ ，拉よび 0.08 といら゙れも低值を示してい る。しかし，内頸動脈系脳血管障害慢性例においても 60 歳以上の高年群に技いては頭部挙上により CBF はやや減 少する傾向にあり, $\triangle \mathrm{CBF} / \triangle \mathrm{MABP}$ は 0.16 と 59 歳以下 の若年群の 0.11 亿比較して低值を示す。

(2) $5 \% \mathrm{CO}_{2}$ 吸入では動脈血 $\mathrm{CO}_{2}$ 分圧の上昇とともに 
限局性脳幹部硬塞例に打いては CBF は高度に増加し, $\Delta \mathrm{CBF} / \mathrm{PaCO}_{2}$ は 3.25 と若年正常例の 3.71 に近似した高 值を示した。内頸動脈系脳血管障害慢性例および仮性球麻 瘏例においてもかなりの $\mathrm{CBF}$ の増加があり $\triangle \mathrm{CBF} / \triangle \mathrm{Pa}$ $\mathrm{CO}_{2}$ はそれぞれ 2.20, および 2.18 である. 内頸動脈系 脳血管障害慢性例のうち高年群においては, $\mathrm{CO}_{2}$ 吸入によ る $\mathrm{CBF}$ の増加率は若年群に压し有意に低下しており, $\Delta \mathrm{CBF} / \Delta \mathrm{PaCO}_{2} 1.08$ と最も低値である.

一方, 内頸動脈系脳血管障害急性例および広範脳幹部硬 塞例においては動脈血 $\mathrm{CO}_{2}$ 分圧が上昇したにもかかわら ず, $\mathrm{CBF}$ の増加は少なく, $\triangle \mathrm{CBF} / \Delta \mathrm{PaCO}_{2}$ は 1.14 およ び 1.26 と低值である.

(3) 脳幹変性疾患例においては, 頭部挙上により進行性 核上性麻痺扣よび Shy-Drager 症候群で高度の CBF 減少 を認め， $\triangle \% \mathrm{CBF} / \triangle \mathrm{MABP}$ はそれぞれ 1.73 ，および 1.72 で，自己調節障害の高度な内頸動脈系脳血管障害急性例の 0.94 に比し更に高値を示している. 一方, $\mathrm{CO}_{2}$ 吸入では, いずれの例においても CBF の増加は著明である.

結語：(1) 内頸動脈系脳血管障害急性例, 広範脳幹部硬 塞例および自律神経障害を示す脳幹変性疾患に扎いては脳 循環の自己調節障害がある.

(2)広範脳幹部硬塞例および内頸動脈系脳血管障害急性 例と慢性例高年群において脳血管の $\mathrm{CO}_{2}$ 反応性の障害が 著明である。

\section{3. 脈血管障害における脳循環の dysautoregulation に 関する研究}

慶大 神経内科

岡安裕之 後藤文男 海老原進一郎 神田 直 山口文衛 天野隆弘 新美次男

脳硬塞急性期に脳循環の dysautoregulation の存在する ことは, 既に明らかにされており，脳血管障害の治療に種 々の問題を提起している，従来，諸家の報告によれば，脳 血管障害急性期約 1 カ月の間, 脳循環の dysautoregulation が認められるとされ，T.I. A., 小発作，動脈閉塞を伴わ ない脳硬塞, 中大脳動脈閉塞の順に, 即ち病巣が広汎に及 ぶもの程, dysautoregulation が長期にわたりみられてい る. しかし dysautoregulation の持続期間について充分な 検討を加えた報告はない。そこで私達は脳硬塞患者を対象 に, dysautoregulation の持続期間を中心に検討を行なっ た.

方法: 対象は, 脳幹部硬塞 7 例, 大脳半球の硬塞 17 例 (脳動脈主幹部閉塞 6 例, 閉塞を確認し得なかったもの 11 例）の計 24 例である。脳循環代謝諸量は $\mathrm{N}_{2} \mathrm{O}$ 法を用い て測定し, 更に tilt table を用いて頭部挙上を行ない, 脳 有効灌流血圧を低下させ, 再度測定を行い, 脳循環の autoregulationを検索した。 また頭部挙上前後で脳動静脈血
の血液ガス分析を行なった。

結果 : 脳幹部硬塞例, 脳主幹動脈閉塞例の中には, 発症 後 $2 \sim 3$ カ月を越えても dysautoregulation を認める例が あり, 特に脳幹部硬塞例においてその傾向が認められた。 同一症例について経時的変化をみた 4 例(脳幹部硬塞 3 例, 主幹動脈閉塞 1 例) では, 脳幹部硬塞 1 例を除き, autoregulation の障害が時間の経過とともに回復する傾向がうか がえた. 脳硬塞の部位別に dysautoregulation の程度を比 較検討すると, 脳幹部障害例では大脳半球障害例に比しそ の程度が高度であった。

結語 : 脳血管障害における脳循環の dysautoregulation について検討し, 次の結果を得た.

1. 脳硬塞患者の dysautoregulation は脳幹部硬塞例で 最も高度であり, 大脳主幹部動脈閉塞例がこれに次ぎ，閉 塞の明らかでない例では軽度であった。

2. 脳幹部硬塞, 主幹部動脈閉塞例では発作後 $2 \sim 3$ カ 月を越えて dysautoregulation の存在する例があり, 特に 脳幹部硬塞例においてその傾向が明らかである.

3. dysautoregulation は経時的に漸次改善傾向を示す.

質問：沢田 徹〈北里大内科〉

脳幹部硬塞では脳循環の dysautoregulation があるとの ことだが,われわれの成績では広範な脳硬塞例では dysautoregulation がみられ, Wallenberg, Foville 症候群などで はこれがみられていない. 脳幹硬塞で dysautoregulatior のある場合, その責任病巣はどこだと括考えになるか.

答 : 岡安裕之

我々の症例は Foville-Millard-Gubler 症候群 2 例, Weber 症候群 1 例, 脳幹部小硬塞 3 例, basilar thrombosis 1 例であるが，障害部位の範囲および局在と, dysautoreg. ulation の障害程度の間に, 現在の所, 明らかな関係は見 い出されていない. 今後, 剖検所見, 症例のつみ重ね等よ りその点を明らかにしていきたいと思う。

質問：新 城之介〈日医大第 2 内科〉

脳血管疾患例では発作後のみならず，長い間脳血流量の 減少か持続していることが多いが，この脳血流量の減少は 脳卒中例にみられる dysantoregulation と何らかの関係が あるかどらか. 打数えいただきたい。

\section{答 : 後藤文男}

全脳血流量の低下の程度と dysautoregulation の程度と の間には必ずしも密接な関係がないところから，全脳血流 量の減少が dysautorgulation の原因として一義的な意味は 持っていないと考光る。脳幹部のおそらく自律神経に関係 した部分の局所的な障害が dysautoregulation と密接な関 係を持っていると考えている.この局所的な障害の原因と しては脳血流低下が関係することはもちろんだが diffuse な脳血流障害は必ずしも必要な条件ではないと考える。

答：田崎義昭 
脳血流減少は dysautoregulationを伴うことはありらる. ただ今の報告は，神経性の dysautoregalation を主として いるが，発作急性期には脳血流減少による化学的因子の関 与もあると思う。

\section{4. 老年者の心, 脳循環動態 一スモーキングテストの 影響および線溶活性一}

神奈川県立成人病センター 内科

松崎 稔 堀井昌子 松井 豊: 上田炤夫 衛藤繁男 塩田善朗

横浜甫大 第 2 内科

築以久一郎 大塚啓子

RISA 使用による体外計浿法で老年者の心, 脳血行動態 を観察し，契煙によるこれら血行動態への影響を壮年者の それと比較した。同時に喫煙の前後で線溶能を測定し喫煙 による影響を検討した。

対象扣よび方法：60 歳以上の喫煙常習者で循環器系に 著変の認め難い老年者 30 名, 59 歳以下の契煙常習者 30 名を刘象として比較した。榆査前 4 日間を禁煙させ，安静 背臥位にて, RISA 静注法により心, 脳血行動態の諸量を 测定, 続いて紙卷タバコ 1 本を約 5 分間で契煙せしめ終了 後ただもに同様の测定を行なった。喫煙前後で静脈血を採 血, $-20^{\circ} \mathrm{C}$ て涷結, 血中 Fbg., Eug LT, Eug LA, Eug $+\mathrm{SK}$ (標準平板, 加熱平板) を测定した.

結果：老年者群では製煙により平均向圧の上昇は認めら れたが，壮年者群にみられたよらな心拍数及び心系数の明 らかな増加がなく, 両群の間に有意の差が認められた。全 末梢血管抵抗は両群共一定の変化は認めなかった。他方, 脳循環系では，一定の傾向のみられなかった壮年者群に比 ベて老年者群では脳血管抵抗の増加がみられ，有意ではな かったが脳血流量の減少傾向がうかがわれた。

老作者群の血中フィブリノーダン，その他の線溶系因子 は, 契煙により一定の変動傾向はみられなかったが, Eug L A はやや下る傾向があり推計学的に有意とはならなかった が少数例で，0に近くまで極端な低值となるものがあった。

考案 : 心脳血行動態への契煙の影響の老年者における特 徵として, 心拍数, 心系数増加への影響が少なく, 他方脳 循環系で脳血管抵抗增大等の影響がうかがわれた点がある。 喫煙の循環系への作用機序としてニコチンによるカテコー ルアミン分泌を介しての作用が重要視されるが, 老年者に おいて,これらに対する反応に特異性があるのか. また, 加 踈による心の機能低下を示唆寸るものか等が考えられる.

Eug LA の極端に下った症例ではフィブリノーゲン值も 下降を示しており，契煙による線溶系への影響を示唆する ものとして注目したい.

\section{5. 脳血栓例における髄液中の数種の線溶関連因子の}

\section{経時的変動 \\ 市立富士宮総令病院 内科 伊与田浩介 河野 靖 遠藤 久 \\ 日医大 第 2 内科 \\ 新城之介川島正博}

䯣液成分は血滩成分および脳組織代謝を反映するといら 観点から，髄液線溶関连蛋白の検索を行なってきた．前回 は健常者 32 例を対象として検索した結果, 剈道液フィブリ ノーゲンは加龄と共に増加するが, 髄液プラスミノーゲン は加齢とは特に関係のないことを報告した。今回は脳血栓 例 9 例を対象とし, 発作時, 1 週後, 4 週後, 及び半年後 の髄液フィブリノーゲン，䯣液 $\alpha_{2}$-マクログロブリン，䯣 液プラスミノーゲンを免疫電気泳動法を用いて測定した結 果, 次の成績を得た。

脳血栓の経過中，髄液フィブリノーゲン，および髄液フ ラスミノーゲンは発作時あるいは 1 週後に最高值を示し， 以後減少する傾向にあった。髄㴑 $\alpha_{2}$-マクログロブリンも ほぼ同様の態度であったが，一部に経過に伴って次第に增 加する症例があった，脳血栓を早期に軽快した症例と回復 の遅れた症例とに分けて検討すると，早期に軽快した症例 では髄液フィブリノーゲンは発作時に高い值を示し以後減 少するが, 髄液プラスミノーゲンは一時的に増加した後に 減少する。賄液 $\alpha_{2}$-マクログロブリンは発作時より，ある いは一時的に増加した後に減少する。回復の遅れた症例て は逆に髄液プラスミノーゲンが発作後次第に減少し, 䯣液 フィブリノーゲンは一時的に増加した後に減少，また，髄 液 $\alpha_{2}$-マクログロブリンは発作後やや遅れて増加するとい う特徵のある動きを示す。これは短期的には髄液フィブリ ノーゲンが, 比較的長期的には髄液 $\alpha_{2}$-マクログロブリン の変動が脳血栓の予後を知る1つの指標となり得ることを 示すものと考える。

犋問：松田 保〈都立老人研臨休第 2 生理〉

測定されたフィブリノーゲンの中には兟疫学的にフィブ リノーゲンと類似の反応を呈する FDP が含まれていない か，濃縮した髄液はトロンビンにより凝固したか。

フィブリノーゲンの量を（十）（H）（H）といらように 示しておられたが，それぞれ，どの程度の濃度のフィブリ ノーゲン量を示しているのか.

質問 : 美原 博〈脳血管研究所美原記念病院〉

(1) 軽快脳血栓例では髄液フィブリノーゲンが次第に減 少し回復の遅いものでは一時増加して後に減少したのは, どのような mechanism の結果と考えるか？

(2) F. D. P., Plasmin などの測定もあわせ行なって, なお一壓の検討をお願いしたい。

質問：阿部恒男〈東医歯大 2 内〉

䯣液中の線溶因子を検討する芬合に䯣液の蛋白量, 白血 球数などとの関連を考えたいのだが，いかがだったか，ま 
た髄液中の線溶因子がすべて血液由来と考えていいの か.

\section{答：伊与田浩介}

(1)なぜフィブリノーゲンが，予後の良し悪しにより態 度が違うのかとの質問に

䯣液の変化は血液成分, 脳組織アクチベーター, 又髄液関 門の問題が相互にからみあって影響をおよぼすと考える。 まず血液成分との比較検討が大切と思われるが, 症例を重 ねて次の機会に報告したいと思う。

(2) 髄液の蛋白の量によっても変化が出てしまうので! ないかとの質問に.

髄液の濃縮は蛋白量 $2 \%$ の濃度として検査した。

(3) フィブリノーゲンは FDPをも含めて検查している が，髄液では FDP が多いのではないかとの質問に，

実際にトロンビントラジロールを加兄てD分画， E分画 を測定すると沈降線は出現しない，私どもは䯣液フィブリ ノーダンを測定する場合アンチクロットを加えている。し たがって䯣液中の FDP は徵量であり, フィブリノーゲン 測定の誤差範囲に入ると思われる.

\section{Studies on aldolase isozyme in cerebrospinal} fluid from patients with cerebrovascular accident by means of isoelectric focusing. Isoelectric focusing 電気泳動法による脳卒中時 髄液 Aldolase 活性上昇の機序の検討

札医大 第 2 内科

田村武雄古堅宗範深井隆夫 赤井るみ子

丹呉寿男 宮原光夫

急性期の脳卒中患者の髄液 Aldolase (ALD) および LDH 活性が脳出血で高く脳硬塞では低く，クモ膜下出血ではほ ぼその中間にあることはすでに報告した。この活性上昇の 機序解明のため, 䯣液酵素活性と血清活性, 䯣液蛋白量およ び細胞数との対比を試みたが，充分な相関は得られなかっ た。そこで今回は Polyacrylamide 平板を使用する isoele ctric focusing 電気泳動法で特に䯣液 ALD 活性の isozyme を検討し，ALD 上昇の機序を追求した，Acrylamide 平板 は LKB manual により $\mathrm{pH} 3.5 \sim 10$ のものを作製. 初電 圧 $200 \mathrm{~V}$, 初電流 $50 \mathrm{~mA}$ で泳動開始. その後漸次電圧を上 昇させ， 2 時間後電圧 $800 \sim 840 \mathrm{~V}$ ，電流 $20 \sim 22 \mathrm{~mA}$ で終 了した。泳動後の平板をPenhoet らの方法に従って染色 し検索に供した。

検体：血清はそのまま使用, 髄液はコロジオンバッグに て約 70〜80 倍に濃縮後 1\% アンフオラインにて数倍に稀 釈して使用。組織はほ湆同量の組織溶解液と共に乳鉢で粉 砕後 $100,800 \mathrm{~g}, 60$ 分遠沈し, 上清を同様に濃縮, 赤血球 溶解液は $1 \%$ 水溶液を用いた。赤血球を検索した理由は, 赤血球が ALD に豊むことから脳出血での髄液 ALD 活性
上昇の一因となる可能性を考罳したためである。

結果：ヒト大細は陽極側（pH4. 1〜4.8）に 2 乃至 5 本か らなる主活性带を認めた，筋肉は㓌極侧 $(\mathrm{pH} 7.6 〜 8.4)$ に 約 5 本からなる主活性部位を認めた。耑者共に $\mathrm{pH} 5 \sim 7.5$ の領國に数本のうすい活性が観察された。このパターンは 多少 $\mathrm{pH}$ の領域は異なるが，それぞれ脳はウサギ脳の，筋 はウサギ筋のisozyme に類似しており，脸分画はALD-C， 䈈は ALD-A と考えられる。血清は活性をを示さないものが 多いが，中央部からやや陽極側にかけて数本の活性を示す あのがあった。正常及び脳硬塞の随液は活性が涩められな かったが, 脳出血の髄液は脳組織のパターンと類似の活㤬 像を示した．赤血球溶解液では中央よりやや陰極よりに主 な活性，中央部及び脳分画所在部位にも薄い活性が見られ た。 クモ膜下出血髄液では赤血球溶解液及び血清との総介 のパターンを示し, 又血清と同じく $\mathrm{pH} 4.7 \sim 5.2$ の部位に Albumin とみられる黄色のバンドが認められた。以上よ

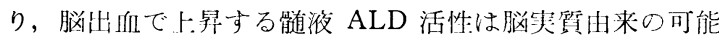
性が，又クモ膜下出血での上昇は血液成分の混入が考えら れた。

\section{7. 脳血管障害と高尿酸血症について}

東大 第 4 内科

西田 毅 高橋統一蚛 小沢英輔 長田洋文 伊藤良 雄

東京顕微鏡院

氏井重幸 奈良一郎 太平千千代次 平岩章好

高尿酸III症が脳血管陾害や心管硬塞などの心血管系命併 症の risk factor の1つとして高血厈症の尒後に影響を及 ぼす可能性が指摘されている，今回，われわれは，高血生 における高尿酸血症の頻度および降䚾郕の影響を調べ，動 脈硬化と関連ある諸因子，さらに脳皿管障彗との関䌽につ いて検討した。

対象は 30 歳以上の高血圧症で 2 次性高血圧と緊障恝の 明らかなものを除いた 920 例と 1969 年より 1973 年の 5 年間に入院又は外来で管理している脳硬塞 54例，兴出向 14例。くも膜下出血10例。計 73 例の兴血管䧛慧患者であ る。その他に 325 人の健傥者を刘照群とした。

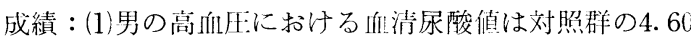
土1.17 に対し，未治療群 5.26士1. 34, 治療群 $5.47 \pm 1.55$

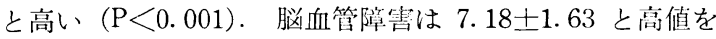
示し治撩群に比しても有意に高い $(\mathrm{P}<0.001)$. 情様に女 性に於いても対照群の $3.68 \pm 0.80$ に対し, 高血圧未治療

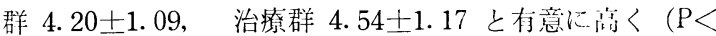
0.001). 治療群と未治療群の差电有怒である $(\mathbb{R}<0.05)$. 脳血管障害の 6.79土1.35 は高血圧治療晧に比しても们意 に高い $(\mathrm{P}<0.001)$ （2）血清尿酸值と年啮领は男性に於い ては特に関係を認めないが，女性では高血左末治療群で加 
龄と共に高值を示し 60 齢以上と 60 齢未満の間に有意差 がある $(\mathrm{P}<0.05)$. (3) 高尿酸血症の頻度は対照群の $3.1 \%$ に対し高血圧未治療群 9.8\%, 治療群 $18.4 \%$ と有意涼 い( $\mathrm{P}<0.01)$. 脳血管障害では脳出血 $57.1 \%$, 脳硬塞 35.2 $\%$, くも膜下出血 $10 \%$ で, 脳出血之脳硬塞の頻度は高血 圧治療群に比較しても有意に高い $(\mathrm{P}<0.01)$.

(4) 正常尿酸との比較で, 高尿酸血症と体重, 血圧, 心 胸比, 眼底, 心電図所見, コレステロール, 自覚症状との 関係では抎張期血圧 $110 \mathrm{mmHg}$ 以上，と血清コレステロ 一ル值 $230 \mathrm{mg} / \mathrm{d} l$ 以上との間に高血圧治療群において有意 の関係を認めた $(\mathrm{P}<0.01)$.

（5）脸血管障害の血清尿酸值の推移を降圧利尿剂の使用 群と非使用群について検討した，発症 3 週間以内では両群 とも $7.86 \pm 1.58 ， 7.81 \pm 2.97$ と高い值を示した。年の後 は利尿剤服用例では高い尿酸值が持続している例が多いの に対し，非服用例では次第に低下し， 1 年以上経過すると 6. $42 \pm 1.49$ となり両群の間に有意差が認められる $(\mathrm{P}<$ $0.01)$.

(6) 脳血管障害の尿酸クリアランスの検討では血清尿酸 值は尿酸・クレアチニンクリアランス比との間に相関係数 -0.43 の負の相関が認められた $(\mathrm{P}<0.05)$.

以上の成績上り高尿酸血症を糖尿病, 高脂血症などとと むに脳血管障害の Poor Risk の1つとして臨床上重視す る必要があると考える。

\section{8. 職域病院における Stroke Clinic の実績と問題点 東京聥信病院 内科 \\ 林弘 平出 聡}

郵政事業内の職域病院として, 最近の新しい脳卒中医療 の要請にこたえるために，既存の人員ならびに施設を工夫 して Stroke Clinic を開設し, 過去 3 年間 144 例の脳卒中 患者の救急（手術を含む），診断ならびに初期リハビリテ ーションを行なって来たが, 病院の守備範囲は首都圈内の 郵政職員とその家族約 12 万人であり， 3 年間の脳卒中発 生 485 件に対し，上記の収容患者数はな抢 $30 \%$ にもみた ない。しかし収容症例は，その $64.2 \%$ が発病後 1 週間以 内の新鮮症例であり，手術を含む救急医療と, CAG, Brain Scan よどよる診断技術面で，昔日の面目を一新したほか， 早期入院の徹底と初期リ八の実施により, 予後の改善も目 ざましく，65.3\% は自立またはほぼ自立の状態で退院す るといら予想外の好成績を挙げ得たが，のこり $35.7 \% の$ 患 者については、リハセンター迄のバトン・タッチは必ずし も円滑に行われず，絶えず相当の労力を要し，とくにリ八 不適の重症固定例については，ナーシングホームなどへの 移送は至難と言ってよく, 当然, 入院の長期化を来たし, 将来, 綜合病院運営上, 重大な問題点が予想される.

脳卒中医療の一般市中病院に拈ける近代化にともない.
12 巻 2 号 $(1975: 3)$

それにつながる後方諸施設，とくにナーシングホームなど の増強は必須であり，国家的な規模でのバック・アップを 強く要望する.

\section{9. 年代別にみた脳出血・脳硬塞の危険因子の比較 一急 性期入院例を中心に一}

秋田県立脳血管研究センター 内科

北村竜男 伊藤敬一川上倖司 小嶋俊一. 渡辺勝宏 览沢尚之

発症 3 週以内に当センターに入院し, 脳血管写等で確診 した脳出血, 脳血管写で閉塞〜狭窄を確認した脳硬塞につ いて, 各々 40 59 歳の若年者群と, 60 歳以上の老年者 群に分け，その危険因子について検討した。

対象は, 脳出血は男 183 例, 女 73 例計 256 例, 脳硬 塞は男 138 例, 女 50 例計 188 例で, 年代別頻度は脳出 血は 70 歳以上でとくに少なく, 脳硬塞は 40 歳代でとく に少なかった．男女別では，いずれの群でも男に頻度が 高く, とくに 40 歳代の脳硬塞は女は少なかった.

これまで多くの報合が，高血圧を risk factor の1つと して認めているが，本研究でも高血圧既往歴の頻度はいず れの群でも高く, 高血圧は共通の risk factor と考えら れ, とくに若年者脳出血群では, 若年者脳硬塞群とくらべ 頻度が高い傾向があった。

心電図変化については Minnesota code III-1.3 をとり あげた。差は見い出せなかったが，脳出血群で頻度が高 く，高血圧の状態がより長く継続していたことを推定させ た.

心房細動は脳硬塞群で頻度が高かった。

眼底所見は S:heie の分類に従がった．若年者，老年者 とも脳出血群でより高度な病変を示す傾向をみとめた.

入院時の尿検査で, 蛋白尿陽性である頻度は非常に高く, 蛋白尿陽性はいずれの群にとっで risk factorの 1 つであ ることが推定される.

総コレステロール值は, $200 \mathrm{mg} / \mathrm{d} l$ 以上は若年者脳硬塞 群にくらべ若年者脳出血群で明らかに少ない。 また, 149 $\mathrm{mg} / \mathrm{d} l$ 以下の例は明らかな差はないが脳出血群に多い傾向 をみとめた。総コレステロール低值は, 若年者脳出血群の Risk factor であることが推定された.

サイフォン部石灰化の出現は若年者脳硬塞群で脳出血群 とくらべ高い傾向をみとめ, 若年者脳硬塞の risk fcator であると推定された。

発症時刻は, 脳出血, 脳硬塞ともに午前 10 時〜午後 6 時にもっとも多く, 労働が発症の誘因として重要な役割を 果しているものと思われる。

まとめ：(1)高血圧の既往歴はいずれの群でも頻度が高く， 共通の risk factor と考えられるが，とくに若年者脳出血 群への影響が強いようであった，(2)心電図所見，眼底所 
見，蛋白尿もいずれの群でも頻度が高く，共通の risk factor 之考学られる。なお，これらの因子は，脳出血群で 頻度が高い傾向にあった。(3)房細動は脳硬塞群で頻度が 高かった. (4)総コレステロール值は脳出血とくに若年者脳 出血群で低值を示す例が多かった。 (4)サイフォン部石灰化 は, 若年者脳硬塞群では risk factor と推定された。

質問 : 荒木五郎〈脳血管研究所, 美原記念病院〉

岡部先生のご質問にも関係するが，私共の成績では，脳 硬塞で就寝中または起床時発症していたものが $40 \%$ 前後 におよび，脳出血では就寝中または起床時発症していたも のが 4 \%に認められている。秋田脳研の成績では, 就寝中 あるいは起床時に発症していた脳硬塞例が少ないよらだが， どうか。

\section{答 : 北村竜男}

脳硬塞対象を血管写上明らかな閉密〜狭窄をしめしたも のにかぎったために就寝中の発症例がみなくなったのかも 知れない，また，他の群とくらべると老年者の脳硬塞では 就寝中の発症も少なくなかった。

質問 : 岡部信彦〈久留米大第 2 内科〉

夜中にすやすやと眠っている最中に発症したことが確実 な脳血管疾患で, 高血圧性脳内出血であることが確実に証 明された症例が，どれ位の頻度にあるか。

答：北村竜男

就寝中に発症した脳出血は頻度は少ないが経験した。

\section{0. 脳血管障害患者の脳浮腫に対する副堅皮質ホルモン 大量療法}

日医大 第 2 内科

比企秀男 新 城之介 赫 彰郎 宮崎 正 宮崎徳 蔵 正田哲一 手塚博幸 伊与田浩介 杉浦晴彦 後 藤良顕 河野 靖 漆山和夫

急性期脳卒中の救急処置は重要で，これまで様々な治㡜 法が報告されているが，我々は脳卒中急性期に起こる脳圧 元進, 脳浮腫の予防ないし除去を目的として副腎皮質ホル モン大量療法を行なったので報告する. 対象は老年者脳血 管障害例で, 脳出血 34名平均年歯 59.6 歳, 脳硬塞 7 名 63. 4歳, クモ膜下出血 23名 57.0 歳の計 64 名である. 投与方法は初回デキサメサゾンに換算して $12 \mathrm{mg}$ 静注し, 2 日目朝, 夕 $6 \mathrm{mg}$ ずつ筋注し, 3 日目 $5 \mathrm{mg}$ ずつ, 4 日 目 $4 \mathrm{mg}$ ずつ, 以下 $2 \mathrm{mg}$ ずつ漸減し， 7 日目までで計 52 $\mathrm{mg}$ 使用した。神経学的評価と䯣液検査, 検尿, 便潜血反 応, 血液一般検査, 血清総蛋白, 蛋白分画, 電解質, BUN, クレアチニン, 総コレステロール, 血糖, 出血凝固時間等 と一部の症例には線溶能を測定し, 投与前. 3 日目, 7 日 目, 10 日目で比較検討した.

脳出血の意識障害レベルよりみた副腎皮質ホルモンの効 果は, 半昏睡, 昏迷例で有効率が高く, 特に意識障害の改
善に有効であった，病巣部位別にみた効果は，大脳半球出 血では，27例中 18 例 $66.7 \%$ 有効を認めたが，脳室出血 は効果が低く、脳幹部出血では無効であった。副腎皮質 ホルモン投与群と過去 3 年間の非投与群とで意識障害の程 度よりみた生存日数を比較すると昏睡例では，1 カ月以上 生存したものが投与群では 12 例中 4 例 $33.3 \%$ であるの に対し, 非投与群では 25 例中 2 例 $8 \%$ であり, 半昏睡, 昏迷例でも 1 カ月以上生存率は投与群 $76.5 \%$, 非投与群 $54.8 \%$ で投与群に有効例が多い。しかし推計学的には有 意の差はみられなかった。投与時の䯣液圧別にみた効果は， 差はみられない，年齢別にみた効果は 65 秢以上の例には 有効率が低い.

クモ膜下出血 23 名に対しての効果は, 昏睡例では 5 例 全例が，意識障害, 䯣膜刺激症状などに無効であり，4例 死亡している。半昏睡例には有効率 50\%, 昏迷，傾眠の 意識障害の軽いものは全例が有効であった。 投与群と過去 3 年間の非投与群との比較では, 推計学的に差はみられず, 生命予後に関してほとんど差が認められなかった。脳硬塞 に対しての効果は, 意識障害レベルとも意識障害が全例改 善しており有効であるが，二重盲検していないので，自然 治瘾による改善も含むものと考兄られ，その効果について は，さらに検討しなければならない，副作用については， 投与総数 64 例の5ち, 投与を急速漸減中止して 3 日以内 に再発作を起して死亡したものが脳出血, クモ膜下出血に 各 1 例, 一時的に意識障害悪化したもの脳出血, クモ膜下 出血に各 1 例あり，㨉与中に吐血，下血により死亡したもの が脳出血例に 1 例あった，その他検查所見の異常はほとん ぞなかった，向後な打症例の選択, 投与方法, 投与量, 副 腎皮質ホルモンの種類などについて検討する必要がある

質問：沢田 徹〈北里大内科〉

われわれも急性期高血圧性脳出血に Steroid を使用して いますが，成績はあまりよくない，とくに発作後 24 時間 以内のものでは，投与群と非投与群に差がでにくいと思う が如何か.

答 : 比企秀男

全例で 24 時間以内に使用開始している.

\section{1. 老年者における脳動脈瘤，高血圧性脸出血術後の 死亡例についての検討}

足利赤十字病院 脳神経外科

数野隆人 上村孝臣 四宮陽一 大木 紘

同内科

奈良昌治 岡本成通 右原伝幸

慶大 脳神経外科

飯坂陽一

人工構成が老龄化を示してくると脳血管障害は増し，艺 年者の脳血管障害に対する手術症例も増加する。脳血管障 
害の場介には, 術前の意識および神経症状の如何が術後の 予後を大きく左右する因子であることは当然である。 な 老年者では合併症が多くなり，それが直接死につながるこ とが多い，我々は 55 歳以上の高齢者で脳動脈瘤, 高血压 性兴H仳の手術症例のうち術後 1 年以内に死亡した症例に ついて死亡原因と術後合併症を検討し，合せて54歳以下の 若年者と比較する。

対象は，脳動脈瘤では，于術例 49例中死亡した 18 例 であり，脳出血では 22例の手術例中の死亡例 11 例であ る。脳動脈瘤においては，手術症例全体に対する老年者の 死亡率は 18.8\%, 若年者 8.3\% であり，また老年者内に おける于術死亡率は $36.7 \%$ ，若年者における手術死亡率 は $17 \%$ である。脳出血においては, 脳出血全体の手術例 に刘する老年者の死亡率は $30.6 \%$, 若年者 $8.3 \%$ である. また老年者内に劣けるす術後の死亡率は $50 \%$ で，若年者 では $21.4 \%$ である。老年者は非常に高い死亡率を示して

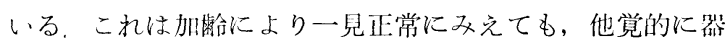
颃的病変や機能異常のみられることが多く，ストレスに刘 しての適応性の減退, 諸蔵器機能の余力の乏しいことのた めであろう. 脳出血が死亡率の高いのは急性期の p or risk のものに対して救命の日们で丁術するが多いことに関係し ている. 死亡の原因は, クモ膜下出血および脳出血による 大さな脳損傷のため死亡するものが脳動脈瘤, 脳出血に非 常に多い，とれを除く之，肺炎，腎不全，心不全，消化管 出盂などの合侀症で死亡している，少なくともこの合作症 そ渽すことにより死亡率は減少される。術前より諸検查絬 䍒に基ついて，また子想される合併症には，積極的に予防 策实脑よ゙こすことにより死亡率はへらしうることを強調し たい。

\section{2. 急性期脳血管障害に対するグリセロールの静脈 内 投与の効果について}

足利赤十字病院 内科

岡本成通 妹尾恭一一荒井洌 馬場健一 石原傅辛

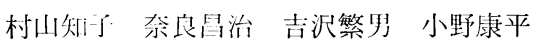
是利赤十字病院 脳神経外科

数野隆人

总性期脳血管障害において hyperosmolar agent である 问挔グリセロール（Gly.）の静脈内投与が脳浮腫を軽減し 脳循璪動態の改善に有効であり更に Gly. は解糖系に入り 細胞の energy 源となり, 脂質代謝に関与し障害された細 胞膜の修復を促進するともいわれる．Gly．の急性脳血管障 害あるいは脳圧え進に対する効果を検討するために急性期 脳纤管障害患者 76 例および脳腫瘍 5 例䯣膜炎 1 例の計82 例に Gly. の静脈内投与を行ない臨床効果と副作用を経時 的に觀察した。重症脳内出血 20 例のらち 6 例に意識状態 改善, 2 例に anisocoria の消失などの効果をみたが, 2 例
に血尿を認めた．頭部外傷 20 例のらち 7 例に意識状態の 改善, 2 例に anisccoria の消失, 3 例に対光反射の正常 化がスられた。くも膜下出血 19例のらち4例に意識状態の 改善, 5 例に anisocoria の消失, 2 例に対光反射の正常 化がみられた。 3 例に軽度の血尿を認めた。

死亡率は重症例を多く含んだため高く脳出血 16/25（64 $\%$ ), 頭部外傷 11/20（55\%）クモ膜下出血 12/19（63\%） と高く, 生存例 25例（脳出血 9 , 頭部外傷 9 , くも膜下 出血 7）のらち 15例は Gly. 投与後開頭術を行ない救命 し得たものである。

脳硬塞 12 例のうち 3 例に意識状態の改善, 1 例に anisocoria の消失, 1 例に刘光反射の正常化がみられた. 3 例 が死亡した，脳王卉進症 6 例（脳腫瘍 5 , 髄膜炎 1 ）の半 数に意識状態の改善がみられた。ことに脳腫瘍手術術前の 患者の状態を control する目的では有効な治療法と考兄ら れた．Gly．の副作用である溶血血尿をを妨ぐため投与方 法を各種試み投与前，直後および 24時間後の末梢血液像 In几清電解質, 血消酵素活性, 血清ビリルビン值, 尿素窒素, クレアチニンなどにつき検討を加えた。 (1) $10 \%$ Gly. in 5 $\%$ Fructose $500 \mathrm{~m} l$. (2) $10 \%$ Gly. in Saline, (3) $15 \%$ Gly. in $5 \%$ Fructose $300 \mathrm{ml}$ の三種の投与法を実施したが, (1)が最も副作用が少なく血清電解質, 酵素活性への影響も 小さく, (2)では数例に血清生化学的変化を来たすものがあ り，(3)では血尿が溞く出現する例があった．しかし腎不全 を来たす例は認められなかった。 Gly. の各臓器に及ぼす 影響をさらに詳しく追求するために23例の剖検例のらち全 身解别を行なった 12 例について主要臟器殊に婜・肝・肺 などの組織病理学的検票を行ったがそのいずれにも急性非 可逆性病変は認められなかった。 高張グリセロールの静脈 内投与は急性期脳血管障害ないし脳圧无進の治療として有 効であり、ことに外科療法の前処置としての効果が認めら れ，溶血血尿などの副作用に対しては投与方法などに留意 して慎重に投一されれば比較的安全旦っ効果的な治療法と 考えられる。

質問：沢田 徹〈北星大内科〉

高血圧性脳出血の場合, herniation が起こったものでも glycerol が有効であった例があるか, われわれの経験では central herniation で高調液により改善を示したものがあ るが, uncal herniation が進行したものでは無効だった.

答 : 岡本成通

完全に脳ヘルニアを起こしているかどらかの判定は難し いと思らが深い昏腫や呼吸異常, 自律神経症状などが軽快 すればある程度の効果があったと考えられる。

\section{3. 高齢者脳出血急性例の治療上の問題点}

秋田県立脳血管研究所 脳神経外科

松岡 茂 伊藤善太郎 
同内外

北村龍男 伊藤敬一 沓沢尚之

1）昭和 44 年 5 月から昭和 49 年 5 月までの 5 年間に 当研究所にて治療を行なった急性期の脳出血例は 288 例で, 混合型脳出血 49 例 (17\%) 外側型 122 例 (42.4\%), 内 側型 65 例 $(22.6 \%)$ 特発性脳出血及び皮質下出 血 5 例 (1. $7 \%)$, 中脳および上部脳幹部出血 8 例 $(2,8 \%)$. 橋出 血 19 例 (6.6\%), 小脳出血 20 例（6.9\%）であったが, 60 歳以上の高年齢層は全体の 35.1\% を占めていた.

2）混合型脳出血は年秢による差はみられないが，外側 型では, 40 歳代が最も多く, 漸次加龄と共に減少するの に対し, 内側型では逆に加令と共に増加し, 60 歳代に peak がある.

3）橋出血は 40 歳代, 50 歳代に多発し, 60 歳代では 極端に減少するのに対し, 小脳出血は, 50 歳代, 60 歳代 に多く, 小脳出血例の $45 \%$ は 60 歳代であった。

4) 大脳半球内出血例の入院時の意識障害の程度をみて みると, 60 歳代は他の年秢層と異なり, 意識明瞭群, 傾 眠, 深昏睡例の占める割合は低く, 昏迷, 半昏睡, 昏筪例 が各々 $25 \%$ を占めていた。

5）大脳半球内出血例の 60 歳代の死亡例をみてみると, 他つ年秢層と異なりやや高く, 昏迷群で $25 \%$, 半昏睡群 で 32\% の死亡率であった.

6）脳室穿破例の頻度は 40 歳〜60 歳代までの間に有 意差は認められないが, その死亡率は 60 歳代が最も高く 83. 3\% であった.

7）この原因を究明する目的で，入院時の血糖值を 50 歳代と 60 歳代について検討してみたが, 脳室穿破例では 50 歳代で $136.7 \pm 43.2 \mathrm{mg} / \mathrm{d} l, 60$ 歳代で $134.2 \pm 46.8 \mathrm{mg}$ $/ \mathrm{d} l$, 非穿破例では 50 歳代では $107 \pm 31.1 \mathrm{mg} / \mathrm{d} l, 60$ 歳 代で $111.4 \pm 28 \mathrm{mg} / \mathrm{d} l$ で有意差はみられなかった。

8）高Na血症の出現頻度を大脳出血例で検討してみると. 60 歳代でやや高く, その死亡率は 70 歳代と共に 75\%で あった。

9）大脳出血例での消化管出血の頻度は，60 歳代で 11. $9 \%$ であったが，その死亡率は最も高く $75 \%$ であり, 消化管出血中, 脳室穿破例の占める割合は, 70 歳代と共 に $50 \%$ と, 最も低く, 他の因子を考虑する必要がある.

10）消化管出血の合併をみない症例では，17-OHCS, Noradrenalin, Adrenalin の尿中排泄量は, 術後 4〜5 日 位より正常值に復するのに対し, 消化管出血例では, 軽症 例でも catecholamine 特に Adrenalinの尿中排泄量は, 異 常に高值を示して北村らが既でに報告した如くアドレナリ ンの尿中排泄量の測定より消化管出血を早期に予测し得る。 それ以外の症例では 60 歳代の高齢者でも, 他の年㱓層と ほぼ同じ傾向があり, 特徵は認められなかった. 以上の事 から, 60 歳以上の高齡者の脳出血例で, 死亡率の高いの
は, 高 $\mathrm{Na}$ 血症, 消化管出血例の出現率が, 他の年龄層に 比しやや高い事, 脳室穿破例の死亡率が高いといった, わ ずかの要因の積み重ねであるのか，他に factor があるの か, 今後さらに検討を要する問題である.

\section{4. 脳血管障害後遺症者に対する Pyridinol Carbamate の長期 Controlled Trial の経験}

\section{慶大内科}

加藤正弘 五島雄一郎 重野幸次

済生会宇都宮病院

宮崎 柏

平井クリニック

平井修司

目的：脳坥管障害の再発予防ひいては生命の予後におよ ぽす薬物 (PDC) の影響を長期の群間比較観察により追求 することである。

対象：特養老人ホーム収容の 35 名であるが, 観察期間 中合併症や副作用のため PDC 服薬を中此した 6 例を除く $\mathrm{PDC}$ 群男 3 , 女 12 計 15 例と対象群男 4 , 女 10 計 14 例を分析した。年齢構成はPDC 群と対象群で発症時平均 は 69 歳之 71 歳で発症より観察開始迄の期間は 4.6 年 と 3.8 年であり, 両群間に有意差はない.

観察方法：期間は 45 年 7 月より 49 年 9 月までの 4 年 2 月間.

検查は運動, 精神機能, 血圧, 心電㘠, 眼底検查, 尿便, 肝機能検李を各年に行ない。一部に脸血管写を前後に行な った。検查の評価は専問医が盲検にて行なった。死亡例は 全例剖検した.

PDC の拈与方法 : PDC 3〜6 錠投与, 併用薬はVit 剂 強心剂, 降圧剂, 血管払張剂（塩パパ etc）等であるが, いずれも両群間に差異はなく, かつ, 観察期間中 1 例を除 いて処方変更は行なわれなかった。

合併症 : 高血圧, 高脂血症, 高尿素血症, 不整脈, 糖尿 病などは両群間に差はない。

成績 : 1. 脳血管障害の再発; 臨床的 CVA 再発は観察 開始前 PDC 群 5 例（7 回）対象群 2 例（2 回）に対し, 観察期間中は 1 例（1回）と6 例（9回）であり PDC 群 に打いて再発例数は $\mathrm{P}<0.1$, 再発回数は $\mathrm{P}<0.01$ と減 少がみられた。 2. 生命の予後 ; 死亡は PDC 群 4 例26. 7 $\%$ に対し対象群 9 例 64. $4 \%$ である。 しかし死亡時年齢 は 75.4 歳と 78.8 歳と対象群がやや高い. 直接の死亡は PDC 群で CVA 再発 1 例, 感染症 3 例, 対象群では再発 3 例, 心筋硬塞 1 例, 感染症 3 例, 墨性新生物 2 例であり 血管死は対象群にやや高率である.

精神機能の推移; 日常行動観察におけるぼけはPDC 群 で不変 12 例, 墨化 3 例, 対象群では不变 5 例, 悪化 $s$ 例 であり, PDC 群に悪化が少ない $(\mathrm{P}<0.05)$. 
運動機能（移動動作）の推移; PDC 群で改善 2, 不変 11 悪化 2 に対し，対象群はそれぞれ $0,10,4$ であり, やや対象群が悪い $(\mathrm{P}<0.1)$. 心電図所見の推移 ; 心筋硬 塞, 伝導障害の発生は対象群に 1,2 例あり, 虚血性変化の 推移は PDC 群で改善 6 例. 不変 13 例, 悪化 2 例に対し 対象群ではそれぞれ $1 ， 12 ， 8$ 例であって前群が良好であ る $(\mathrm{P}<0.01)$.

眼底所見の推移では改善率に有意差はない.

副作用としては胃腸障害のみで肝障害はない。

まとめ; PDC は高踴者 CVA 後遺症者の再発を阻止し, 精神機能心電図所見に良好な影響を与える，延命効果につ いては今後の follow up による確認を要する.

\section{5. 老年者脳血管障害に対する Efenprodil Tartrate の 脳代謝面からの検討}

国家公務員共済組合連合会立川病院 内科 古見耕一 森 皎鿆 前田謙次 石川俊次 山田隆一 郎 相澤豊三

われわれは，脳血管障害の臨床に使用されている種々薬 物の効果を脳ミトコンドリア呼吸機能の面より検討してい るが, 今回, フランスで開発され脳代謝改善作用が示唆さ れている efenprodil tartrateについて検討する機会を得た ので, 若干の臨床治験も含め報告する。

方法：動物実験は，自家凝血紐片注入法により脳血管障 害家鬼を作成し, efenprodil tartrate を静注した群を加療 群とし, 無処置脳血管障害群, 正常対照群とを比較検討し た. 脳ミトュンドリア呼吸機能の測定は酸素電極法によ り, 呼吸機能諸量の呼吸調節率 $(\mathrm{RCR})$ コハク酸脱水素酵 素活性 ( $\mathrm{SDH}$ 活性) 酸素摂取量 $\left(\mathrm{O}_{2}\right.$ uptake) は, トレー スより求めた. 臨床例については, 従来の方法で治療して いるにもかかわらず 2 3 の症状が軽快しないか，または 一進一退を示している慢性期の脳血管障害患者の中から無 選択的に選び, 本剤を経口的に投与して, 自覚症状, 精神 症状, 他覚的神経症状に対する効果を判定した. 判定基準 は，おのおのの症状が投与前に比し完全に消失したものを 著効, 軽快したものを有効, 軽快するが動摇するものをや や有効, 全く変化のないものを無効とした.

成績および考案 : 加療群の RCR は, 無処置群のそれに 比し推計学的に有意の改善がみられたが, SDH 活性, $\mathrm{O}_{2}$ uptake には有意差はみられなかった。この結果は, 以前 検討したステロイドの実験結果に類似しており，虚血脳を 保護する何らかの作用は示唆されるが，直接的な代謝改善 作用を示めすものではない，臨床例では，めまい，めまい 感, 頭重などの自覚症状に改善率が高かったが, これは椎 骨脳底動脈系の血流改善がより著明であるとする脸循環面 の報告と照し興味深い。自発性の低下, 記銘力障害など精 神症状の改善については, さらに局所脳循環面よりの検討
も必要と考える. なお, 他覚的神経症状にはみるべき効果 は認めなかった。副作用の出現は一例もなかった，

結語 : efenprodil tartrate を実験的脳血管障害家鬼の脳 ミトコンドリア呼吸機能の面より検討した結果, 虚血脳を 保護する何らかの作用は示唆されたが, 直接的な代謝改善 作用は認めなかった，また，臨床面では，めまい, 頭重な どの自覚症状に改善率が高く, 精神症状では自発性の低 下, 記銘力障害に効果がみられた。

\section{6. 老人性疾患と血小板疑集能（第 1 報）脳卒中と SFP 法による血小板凝集能の関連}

長野県厚生連鹿教湯病院

小林逸郎 眭上香代子 北城祥子 藤田 勉

目的：血小板は傷害された血管またり動脈硬化性変化を 生じつつある血管壁表面に粘着し, 血栓の根をつくり同時 に血小板凝集現象も重要視される．出血に関しては血管壁 と血液凝固学的な関連があるが,こと脳出血に関しては血 管の小動脈瘤の破掟によっておこることされており血小板 $\mathrm{ADP}$ 凝集との関連についての報告はまだ数少ない. この ような観点から高血圧, 脳出血, 脳血栓等の各疾患に拉け る血小板凝集能（SFP 值）との関連について検討した,

対象: 健康者群 50 名 $(64.0 \pm 9.4$ 歳, 平均士標準偏差), 高血圧症群 93 名（65.6土8.5 歳）およびリハにて入院中 発症より 3 力月以上経過した脳血栓症 155 名 (63.9土9.1 歳), 脳出血症 71 名（58.6 18.0 歳）また入院中に再発 または発作後 2 日以内に入院して来た急性期の脳血栓症 10 名（66.8土9.5 歳）および脳出血症 17 名（65.6 10.6 歳） について発症より約 $3 \sim 6$ カ月間にわたり血小板凝集能の 測定を行なった。

方法 : SFP法の測定にあたってはその方法はすでに Swank によって詳しく報告されて扣り，それに準じた．

成績 : 健康者, 高血圧症, 脳出血症および脳血栓症のSFP 值：男女共あわせて健康者は $143.2 \pm 44.5 \mathrm{mmHg}$ (平均 （土）標準偏差）であった，高血圧症では $174.8 \pm 73.2 \mathrm{~mm}$ $\mathrm{Hg}$, 脳出血症では $182.5 \pm 60.9 \mathrm{mmHg}$ であった. 脳血栓症 では 195.8土69. $0 \mathrm{mmHg}$ であった. 次いで疾患別に男女別 にみると男性群に打外る健康者は $131.7 \pm 21.9 \mathrm{mmHg}$, 高 血圧症 $150.9 \pm 55.4$, 脳出血症 $174.1 \pm 63.7 \mathrm{mmHg}$, 脳血 栓症 $178.1 \pm 69.3 \mathrm{mmHg}$ であった. 女性群における健康 者は $154.6 \pm 56.3 \mathrm{mmHg}$, 高血圧症 $195.4 \pm 80.1 \mathrm{mmHg}$, 脳出血症 $190.9 \pm 68.1 \mathrm{mmHg}$, 脳血栓症 $220.9 \pm 60.1 \mathrm{~mm}$ $\mathrm{Hg}$ であった. 新鮮脳出血および脳血栓のS SFP 值: 発作 10 日以内の脳出血症の SFP 值は $142.4 \pm 52.5 \mathrm{mmHg}$, 脳 血栓症では $241.3 \pm 65.4 \mathrm{mmHg}$ であった. 以後脳出血症 の SFP 值は漸次上昇し脳血栓症では下降し 6 力月後に脳 出血症では $210.0 \mathrm{mmHg}$, 脳血栓症では $240.0 \mathrm{mmHg}$ と 両者ほぼ似た值を示した。 
結論：(1) 高血圧症, 脳出血症の SFP 值は健康人に比 へ高值を示した。脳血栓症では $5 \%$ 以下の危険率で健康 者に比べ有意に高い值を示した $(\mathrm{P}<0.05)$. 各疾患におけ る男性群と女性群の間には男性群より女性群の方が各疾患 ともに SFP 值は高い値を示した。

（2）急性期脳出血症と脳血栓症の間に血小板凝集能の違 いが見られ脳出血症では脳血栓症に比べ有意に低い值を示 した $(\mathrm{P}<0.05)$. 以後脳出血症の SFP 值は漸次上昇し脳 血栓症では下降し 6 力月後には両者ともにほ匡じ值を示 した.

質問：松田 保〈都立老人研 臨床第 2 生理〉

SFP 值には, 血小板数, ヘマトクリット值が影響を及 ぽすと思うが, 先生の測定された症例では変動していたか.

\section{答 : 小林逸郎}

Platelet 数には正の相関があるが，その相関係数はかな り低く，数については無視できると思う。

Het については，逆相関して，この相関係数はかなり高 く，1\% Hct が上昇すると SFP 值は $8 \mathrm{mmHg}$ 低くなる. 女性の SFP 值が高いのもこの Hct の Factor をかなりふ くさためと考える。

\section{8. 脳血管障害者における知鸴運動学習}

東京都老人総合研究所 心理学部

聖マリアンナ医科大学 神経精神科

伊豆韮山温泉病院

守屋国光

長谷川和夫

長谷川恒雄 竹田契一

脳血管障害は主として高跘者に多くみられる脳の病的老 化の 1 つであり, 加齢に伴ら脳の老化現象を解明する上 で，多くの示唆を含んでいると考えられる，そこで，脳血 管障害者を対象として, Pursuit Rotor Task を課題とし てそこにどのよらな知覚運動学習の過程がみとめられる かについて, 失語群一非失語群, 右マヒ群一左マヒ群のそ れぞれについて，比較検討を試みた。

Pursuit Rotor Task とは，回転する円盤上の1点を手 にした追跡器で追うものであり，(1) その学習の過程を比 転的容易に数量化でき分析しやすい，(2) その教示の段階 には多少の言語を伴うとしても，課題とのものに対する直 接的な言語の介入がほとんどない（3) 学習課題が新奇な 目新しいものであることから, 学習の過程を最初から吟味 できる.（4）実験条件の統制がかなり厳密に行なえる，と いった諸点からして, 脳血管障害者の学習過程を哈味する 上で比較的妥当な研究方法である.

全部で 40 名の脳血管障害者（男性）を対象として，個 別に Pursuit Rotor Task を行なわせた. やり方は, 1 回 100 秒の追跡作業を 1 日 4 試行計 400 秒（試行間休稹は
60 秒)，これを 5 日間連続させて行なわせた，回転速度は 時計と同じ方向で $40 \mathrm{rpm}$ であった。このようにして得ら れた資料のらち，次の基準にもとついて今回は最終的に 24 名の資料を用いて分析を行なった。すなわち，その基準と は, (1) WAIS の動作性検査の結果が評価点合計で 21 以 上（55～64 歳の年龄基準で P. I. Q が 70 以上に相当する） であること，(2) Benton 視覚記銘検査結果で正確数が 3 以上，䛊謬数が 15 以下であること，(3) 上下肢にマヒ側 があり，しかも片マヒであること，(4) 視力に課題遂行上 で問題がなく, 視野の異常がないこと，(5) 課題遂行時に 強い疲労の訴えがみられなかったこと, の5つの点である 24 名は 8 名ずつ次の 3 群に分けられた。すなわち, 右、 ヒで失語症状を呈する失語群, 右マヒで失語症状のない非 失語右マヒ群, 左マヒで失語症状のない非失語左マヒ群で ある. いずれも年齢は 50 ７6 歳の間であり，病前の利き 手は右手利きである。課題遂行の際には, いずれも非マヒ 側の手を使用させた。

結果として，次のような傾向が窺われた。(1) 失語群と 非失語群とでは, 知覚運動学習過程が多少とも異なってお り, 失語群の方が学習の達成量が多い.

(2) マヒ側が右侧であるか左側であるかという差は，非 失語群でみる限り, 知覚運動学倪の上では, ほとんど差が ないようである，以上の点については，今後さらに資料を 充実させて，より詳紼に検討していきたいと考えている.

\section{9. 脳血管障害に合併する肩手症候群について}

東大 老人科

江藤文夫 · 吉川政己

東大リハビリテーション部

三浦聁雄 上田 敏

群大リ八研

平井俊策 森松光紀

近年, 脸卒中のリハビリテーションの活発化に伴い.そ の拣施の上で，合併症の早期発見と適切な管理治療は大き な意味を持っている. Shoulder-Hand Syndrome（肩手症 候群）は 1947 年, Steinbrocker によって定義されたもの であるが，その痛みと運動制限がリハビリテーションの実 施を著しく遅延させる点で，脳卒中に打ける重要な介併症 であるが, 比較的, 諸家の関心が薄く, 充分な研究がなさ れていない. 今回, 我々は過去 10 年間に拈ける東大老人 科入院掞よび外来症例, 邀去 5 年間に拈ける東大りハビリ テーション部症例を中心に, 片麻痺に合併する本症候群に ついて分析し, 併せて, その発生機序に関して, 指尖容積 脈波による若干の知見を得たので報告する.

結果：I-1)片麻痺における本症候群の発生率は過去 10 年間に沶ける東大老人科入院症例, 同外来症例, 過去 5 年 間に拈ける東大リハビリテーション部症例, 過去 5 年間に 
おける初石病院入院症例, 1974 年 8 月 31 日現在の石和 リハビリテーション病院入院患者について, それぞれ, 24. $0 \%, 19.0 \%, 24.3 \%, 15.0 \%, 19.4 \%$ であった. (2) 脳硬 塞と脳出血とでは本症候群の発生率に差はみられない. (3) 性別による発生率の差はみられない. (4)年齢と発生率に関 しては, 40 藏未満には本症候群の合併した症例はなく, 50 歳代で，有意に発生率が高く（35.3\%). 概して高齢者 に目立つ. (5)麻舫側との関連については, 左麻疩にや〉多 い印象があるが，有意差はない。(6)片麻瘏発症から本症候 群出現までの期間は約 $74 \%$ が 3 力月以内, 全例平均 2.3 カ月であった。 (7)麻痺の程度との関連では, Brunnstrom のテストおよびそれに準じた上田・福屋のテストを用いて 片麻痺の回復段階を評価し検討したところ, Stage III 以下 の重症例に有意に発生率が高く，上肢之下肢の回復段階を みると．下肢に比し上肢の回復が劣るものに多くみられた。 (8)右片麻痺においては失語症を合併した症例に本症 候群 の発生が目立つ. II-1936 年 Ellis は片麻㽻患者の未梢血 の $\mathrm{O}_{2}$ 濃度の測定をもとに麻瘏側の血流が増大しているこ とを報告しているが, 我々は光電脈波計により指尖容積脈 波を検查し，この点について検討したところ，本症候群を 伴わない片麻痺では必ずしも血流量増加を認めないが，本 症倓群を伴う片麻痺に颃いては, 麻痺側の末梢血管抵抗の 減少と血流量増加を有意に認めた。このことが，本症候群 発生の原因に関与するのか結果であるかは今後検討を要す る問題であるが従来の自律神経障害説を評価する上で非常 に興味ある知見である。

質問 : 三島博信〈洞爺協会病院〉

肩手症候群の発生は私達の施設ではもう少し多いように 思われる。

(1) 回復率は（治療により）どのくらいあったか。

(2) 疼みと関節拘縮との関連性で报聞きしたいのだが. 関節拘縮を伴った例はどのくらいあったか.

答 : 江藤文夫

(1) S-H-S の頻度はスライドに示したとおり，15.0〜 $24.3 \%$ である. 施設による差は主として S-H-S の発症 が脳卒中発作后 3 ヶ月以内に多く Stage II 以上に進むと, 既に痛み，畽脹か消失し診断が困難になるためと考えられ る.

(2) S-H-S の経過および肩関節拘縮の頻度等に関して は, Stage I の段階で治療（温熱，ROM-ex, Steroid 投 与, Stellate ggl, Block 等) を実施したものでは，拘縮を 起こすことは非常に稀である，放置して自然経過をみた例 はないが，従来の報告では自然治瘱する例もあるようであ る.ただし, Stage II 乃至 III の時期から治療を実施した例 ではほとんど効果がみられず。約半数以上は肩や手指の拘 縮を残す。なお肩関節亜脱田を $40 \%$ 前後の S-H-S に認 めた。
12 巻 2 号 $(1975: 3)$

30. 脳血管障害後遺症者と危険因子（第 1 報）高血圧，糖 尿病, 高脂血症および年齢と脳血管障害後遗症者の種 々症状との関連

伊豆菲山温泉病院 内科

岸 久博

脳血管障害の rick factor と言われているもの〉内，高 血圧, 糖尿病, 高脂血症を取り上げ, これらが脳血管陾害 後遺症者に扣いて, その発生, 合併症, 症状, 麻疩の回復, 生命の予後に如何なる関連を有するかを，過去 5 年間に当 院に入院した脳血管障害後遺症者 512 名について，年齢の 因子も加味して検討した。

高血圧, 糖尿病, 高脂血症の 3 者の有無により 8 群に分 け，これを基本として検討した，検討した項目は，脳血管 障害の原因疾患として脳血栓，脳出血を取り上げ，当院で の調査で, 社会復㷌と生命の予後に関連の深いもの>内, 合併症として冠障害, 腎障害, 心不全, 感染症を, また広 範な大脳機能障害を推測もせるものとして, 知能障害, 感 情失禁, 尿失禁, 構音障害, 嚥下障害, 心理状態, 意欲異 常を，次いで上肢および下肢の麻㾝の回復を取りあげ，最 後に生命の予後を取りあげた。

その結果は次のようであった。

(1) 脳血管障害の原因疾患のうち, 脳血栓に対しては, 高血压，糖尿病，年齢の関与が深く，高脂血症は関連がな い.

脳出血に対しては, 若年（59 歳以下）の高血圧の関与 が深いが, 高齢（60 歳以上）での高血压，糖尿病群，高 齢群では脳出血の頻度はむしろ減少しており，高脂血症は ほとんど関連がない。

(2) 合併症では，冠，腎障害に高血圧，糖㽷病，年齢の 関与が大きく, 高脂血症は関連がない. 感染症, 心不全で は，年齢の関与以外には, 一定の傾向は認められなかった。

(3)広範な大脳機能障害を推測させる諸症状には, 年齢 の関与が強く, 高血圧, 糖尿病, 高脂血症は関連がない.

(4) 麻痺の回復には高血圧，糖尿病，高脂血症は影響を 与えない。

(5) 血管死に対しては, 高血圧, 糖尿病, 年龄の関連が 深く, 高脂血症群では, これの無い群より血管死の頻度が 低い.

\section{1. 脳血栓の長期予後}

福大 内科

西丸雄也

九大 第 2 内科

尾前照雄

脳血栓発症後 1 力月以上生存した 151 例について 5 年間 の追跡調査を行ない. 発症時の年龄によって 60 歳末満と 60 歳以上に分け, 臨床症状, 検査所見が長期子後に扣よ 
ぼす意義の相異について検討した.

全症例の年柃は $23 \sim 85$ 歳, 平均 58.5 歳であった。 そ の生存率は 1 年後 $87 \%, 2$ 年後 $81 \%, 3$ 年後 $74 \%, 4$ 年後 $71 \% ， 5$ 年後 $63 \%$ で，これらは年跉別，性別の全 死因死亡率より算出した期待生存率より低值であった。さ らに年龄階級別に比較すると, 老齢者になるほど期待值と 実際の生存率との開きは大きくなっていた，死区は脳血管 性障害 23 例, 心疾患 5 例, 感染症 10 例, 悪性腫瘍 9 例 その他 9 例であった。

60 歳未満の症例では, 収縮期血圧 $160 \mathrm{mmHg}$ 以上の場 合に生存率が低下し，抎張期血圧 $100 \mathrm{mmHg}$ 以上の場合 に生存率の低下の傾向がみられ, 脳血栓の既往, 意識障害, 高度の脱落症状, 脳波異常, 心電龱, 眼底所見, 脳動脈狭 窄，脳循環などは生存率に大さな影響を与えていなかっ た.

60 歳以上の症例では, 脳血栓の既往, 意識障害, 発症 2 力月の改善不良, 脳波の中 ·高度異常の場合に生存率が 低下し, 発症時の高度脱落症状, 収縮期血圧 $160 \mathrm{mmHg}$ 以 上, 心電図異常, 脳動脈狭窄, 頭部血流量の低下の場合に 生存率の低下の傾向がみられ，抎張期血圧 $100 \mathrm{mmHg}$ 以 上, 眼底所見は生存率に大きな影響がみられなかった. 特 に 60 歳以上の場合には脳波異常と神経脱落症状の長期生 存率におよぼす影響が大きいと考えられた。

質問 : 山岡三郎〈警友病院〉

再発が，原病と同じ病型でないもの（原病出血 $\rightarrow$ 再発, 硬塞のごとき）例は，頻度はどれ位か？

答: 西丸雄也

脳血栓 151 例の 3 年間の再発 27 症例のらち 1 例は剖検 により，1例は臨床的に診断された脳出血を経験している.

\section{2. 脳硬塞, 脳出血の遠隔成績一特に高齢者の予後につい} $\tau-$

\section{脳血管研究所美原記念病院}

荒木五郎 水上公宏 全 弘 美原 博

われわれが治療した脳卒中患者が果していかなる転㷌を とったか,これを明らかにすることは臨床医にとっての責 任でもあり，また治療方法の反省にも大切なことと考える。

1) 対象, 当院に打いて入院治療を受けた脳血栓267例(男 175, 女 92), 脳出血 134 例（男 98, 女 36）で, これら の転帰について追跡調査を行なった. 死因は当院外での死 亡者は他の主治医の死亡診断書によった。 年齡は脳血栓, 脳出血とも 60 歳代に多いが, 脳血栓では脳出血に比べ70 歳代が著しく多い. 2) 追跡調査. 脳血栓では, 生存者数 は 267 例中 138 例で, 観察期間はすべて 3 年以上で, 長 いものは 10 年におよぶ. 死亡者は 129 例で, 3 年間で半 数以上が死亡している. そこで 3 年の時点でみると，その 死亡率は $26.5 \%$ となる. 脳出血では, 生存者は 134 例中
68 例で, すべて 4 年以上の観察が行なわれ, 死亡は 66 例 で 1 カ月以内の死亡は脳血栓に比べ， 2 倍以上の割合に多 くなっている. また 3 年間では約 $80 \%$ が死亡する. 3 年 の時点での死亡率は $40.3 \%$ の高率を示す. 3）死亡の原 因, 初回発作死亡とは, 肺炎あるいは消化管出血に上る死 亡であっても, 初回発作に引き続き死亡したすべてを意味 する. 脳血栓では, 初回発作死亡の殆どが 6 カ月以内で, 全体の $13.1 \%$ に相当する. 再発死亡山全体の約 $50 \%$ を 占め, 1 カ月から始まり 1 年より 6 年までに多数認められ る.

一方脳出血では初回発作が $54.5 \%$ を占め, 1 週以内に 最も多く, 再発死亡は, 1 年から 3 年にかけてピークを認 め, 全体の $31.8 \%$ に相当する. 4) 脳血栓と脳出血との 死因の比較. 初回発作死亡は脳血栓 $13.1 \%$ に比べ, 脳出 血は $54.5 \%$ と多くなる. 再発死亡は，脳出血の $31.8 \%$ に比べ，脳血栓は $50 \%$ を示す. 心疾患死亡についても脳 血栓が 3 倍近くの割合に多数をかぞえる. 肺炎は両者に差 異はない.5）初回発作より再発死亡までの期間. 脳血栓 では 1〜3 カ月に $4.6 \%$ 認められるが, 脳出血では 6 カ 月以上 1 年以内から始まっている. 脳血栓は 1 年から 2 年 にかけてピークがあるが，8年経過後も再発死亡が比較的 多く認められる. 一方脳出血では 1 年から 2 年にかけて非 常に高いピーク（42.8\%）を示す．6）脳血管写所見と死 亡率. 脳血栓では内頸動脈閉塞 $71.4 \%$, 中大脳動脈起始 部閉塞が $64.1 \%$ で, 狭窄, 正常の順に低くなる. 脳出血 では, 被毅出血 $35.8 \%$, 視床出血 $50 \%$ となるが, 脳室 穿破型はいずれも $70 \%$ 以上の高い死亡率を示す。7） 65 歳以上（発病年龆）の高㱓者の死亡率. 脳血栓では 64 歳 以下 $14.0 \%$ に比べ, 65 歳以上では $40.4 \%$ と著しく高 率となる。また脳出血では $36.4 \%$ から $51.4 \%$ とやや高 跘者に高くなる。

答 : 荒木五郎

脳出血が脳血栓の再発作をおこすこともあるが，頻度は 少ないと思う。脳血栓は脳血栓の再発が多く，脳出血とな る率は脳出血が再発作として脳血栓となる率よりさらに頻 度は低い。

\section{3. 脈血管障害患者の 20 年にわたる短期および長期予後 について}

国立名古屋病院 内科

伊藤栄一 橋本勇次 阿久津晄 水口一德

昭和 29 年より同 48 年までに国立名古屋病院に入院し た 1,071 例, 外来を訪れた 378 例の計 1,447 例の脳血管 障害患者を対象として, 急性期死亡も含めて 6 力月以上 20 年の予後調査を行なった. 予後の追跡できたものは 1,091 例の $75.3 \%$ で, 調查方法は直接診療によるもの 538 例, アンケート 413 例, 電話 140 例で, らち 559 例の死亡が 
$12: 92$

日本老年医学会雑誌

確認された. その短期 - 長期予後と病型, 性, 年齢, 病変 部位, 高血圧の有無との関係, TIA の頻度とその予後, 再発作の病型と病変部位, 死因と死亡時期について検討し, あわせて欧米に打ける報告と比較対照した。

その結果をまとめると，1）病型別では発症 1 力月以内 の死亡率は脳出血 $41.1 \%$, 脳血栓 $8.8 \%$ と脳出血の急性 期予後が覀かったが, Whisnant らの $83 \%$ に比べればは るかによかった. また脳出血と脳血栓の生存率は 10 年後 に初めて有意差がなくなった，2）性別では 2 年以内の女 性の予後がやや悪かった. 3）年秢別では 60 歳以上, こ とに 70 歳以上の予後が短期・長期とも悪かった. 4) 椎 骨脳底動脈領域と内頸動脈領域の血管障害ではその予後に 差はなかった。 5 ）高血圧症の有無と予後との関係ははっ きりしなかった。このことは患者扣よび医師が高血圧の存 在を再発作の危険因子と考え，管理が行なわれる結果とし て受けとめたい，6）TIA は 6\% にみられたに過ぎず, 脳血栓で TIA が先行したものは 5.7\% で, TIA 後脳出 血, クモ膜下出血を生じたものが各 1 例, 脳動静脈奇形の 1 例があった. TIA 22 例の追跡では消化管出血死 2 , 癌 死 1 例があり, 脳血栓の発症は 1 例もなく, 欧米で強調さ れるほど危険因子としての価値は低いよらに思われる，7） 再発作の病型, 血管支配領域や病変部位が確定または推定 された 116 例についての調査では, 初回発作と違った病型 の再発作がとさにみられることもあり, 同側と対側の割合 は脳出血では 13 対 7 , 脳血栓では 29 対 12 (ほかに初 回内頸動脈系で再発作が推骨動脈系のもの 5, その逆が 1 例）と再発作は他の血管領域にも比較的多く生ずることが わかった. 8）死亡例 559 例についての死亡時期と直接死 因の検索では，1 カ月以内の急性期では $85.3 \%$ が脳血管 障害で死亡し, これに消化器合併症がついだ. 1 力月以降 の死亡は脳血管障害が $50 \%$ ，心・血管系合併症が $11 \%$ と これについだが, アメリカに打ける脳血管障害再発作死亡 の 9 から 23\% という低值, 心死の 20 ないし $42 \%$ とい う高値とは明かな違いがあり，これは民族的な差違として 受けとめたい。また急性期の消化器合併症も無視できな い.

\section{質問 : 岡部信彦〈久留米大第 2 内科〉}

一過性脳虚血発作の診療は, 全く, 患者側の述へるとこ ろによらざるを得ないので, 病歴の信頼度が先ず問題とな ると思う.この点に関してご経験を扣教えいただきたい.

\section{答 : 伊藤栄一}

死亡 559 例中初回発作が脳出血 186 例中脳出血で死亡 したものは 129 , 初回発作脳血栓が 258 例中脳血栓死が 121 例 (46.9\%) である. 再発作の確認できたもののらち 初回脳出血で 31 例のらち再発作脳血栓 2 例, 初回脳血栓 発作 45 例中再発作が脳出血であったものが 1 例あった。

答 : 伊藤栄一

\section{2巻 2 号 $(1975: 3)$}

TIA については昭和 38 年から 11 年間についてはき わめてくわしくその有無について聴取した. これは患者の みでなく家族及びその他の人たちからもできるたけ情報を え，正確を期するようにした。

質問 : 三島博信〈洞爺協会病院〉

(1) 虚血発作については, 私共の経験では, テンカン発 作が含まれることがあるので注意を要すると思う。

(2) 私共が行なった昨年の北海道での CVA 患者の生存 率では 5 年以上生存するもの $30 \%$ 以上, 10 年以上生存 するものも $15 \%$ 以上あった。伊藤先生のご調査で, 出血, 硬塞について 5 年以上の生存率, 10 年以上の生存率がわ かって拉られたらご教示いただきたい。

\section{答 : 伊藤栄一}

5 年, 10 年における死亡率は, 病型別にみてみると脳 血栓 5 年で $50.2 \%$, 脳出血 5 年で $32.5 \%$, 脳血栓 10 年 で $22.7 \%$, 脳出血 10 年で $18.1 \%$ となっている.

\section{4. ヒト頸動脈硬化定量に関する研究 一icrospectro-} photometer による中膜組織エラスチンの定量一

慈医大 第 1 内科

荒井親雄 阿部正威 川崎正威 川崎 健

長谷川元治 吉村正蔵

慈医大 $\mathrm{ME}$ 研究室

菅野亮一

文部省統計数理研究所

木下重博

上智大 理工学部電子 工学科

八木普一

目的：頸動脈は系統的動脈硬化分 布特性に関連して特に 脳動脈との関連が注目される. 本席では血管の弾性特性の 主要因たる中膜弾性線維網の主成分ェラスチンを組織化学 的に測定し形態因子を加味した頸動脈病理組織所見を定量 し脳動脈基幹部，大動脈硬化との関係について検討を行な った.

対象および方法：対象は生前大動脈波速度を計測し剖検 しえたもの 31 例, その他剖検例のみ例計 52 例である. 顕微分光光度計による中膜エラスチンの定量法は本年度脈 管学会において報告したので省略する，また口径，壁口， 狭窄度についても計測を行なった。

結果：1）頸動脈に拈ける壁厚と内半径の関係は相関係 数 -0.198 のやや逆相関的傾向がみられたが両者の関係は 明らかではなかった。また壁厚の平均は $0.68 \mathrm{~mm}$, 内半径 2.6mm であった. 2) 生前の最大, 最小血圧と頸動脈内 半径の間に一定の関係は認められなかった。3）年代別に エラスチン量をみると $20 \mathrm{vol} \%$ から $35 \mathrm{vol} \%$ の間に分 布し加龄に伴ら変化は明らかではない.しかし脳硬塞, 心 筋硬塞など動脈硬化性疾患においては $25 \mathrm{vol} \%$ 以下の低 
い値を示した。 全体の頸動脈エラスチン量の平均は $27 \%$ であった。若年者において $20 \%$ 台の低值を示したものは 主に尿毒症の症例であった. 年齢とエラスチン量の相関係 数 0.115 はであった. 4) 年代別に狭窄度をみた場合加秢 に伴い狭窄度は増加の傾向を示すがその程度は軽く血行学 的に障害となる程の狭窄を認めるものはなかった。これは 日本人に拈ける頸動脈硬化の特異性と考えられる.両者の 相関係数は 0.322 であった. 5) 頸動脈狭窄度と脳動脈硬 化との関係をみると脳動脈硬化著明なものに狭窄度の大な るものが認められるが硬化著明例においても狭窄度小なる ものがみられ脳動脈硬化を狭窄度の低いことで否定できな い.6）大動脈脈波速度と頸動脈狭窄度をみると 0.532 の 相関を認めた. $7 \mathrm{~m} / \mathrm{sec}$ 以下では狭窄度 $10 \%$ 以下である が $8 \mathrm{~m} / \mathrm{sec}$ 以上に拈いては $10 \%$ から $40 \%$ と幅のある值 を示した.

9）頸動脈エラスチン量と脈波速度との関係をみると一 0.268 の負の相関を認めた. 脈波速度の低值を示すものに もェラスチン量は $18 \%$ から $38 \%$ と幅広い値を示したが $9 \mathrm{~m} / \mathrm{sec}$ 以上に拈いては $25 \%$ 以下の例が大部分をしめて いる.

結語 : 1) 頸動脈の壁厚と内半径の間に一定の関係を認 めなかった．2）頸動脈狭窄度は一般的に軽度であった.

3）脈波速度と頸動脈エラスチン量とは逆相関を認めた。

4）動脈硬化性疾患, 脳動脈硬化例において頸動脈エラス チン量の低下を認めた。

\section{5. 脳血管障害にかんする研究一続報 一顒動脈領域のク} ランプによる内皮細胞の微細構造上の変化とその要 因一

東医歯大 第 3 内科

須永俊明 藤野秀明 塩谷 豊 内村 功

東海大

\section{島本多喜雄}

脳血流障害の 1 つとして, No-Reflow 現象が注目され, Majnos によって, 脳内諸血管内及び内皮細胞の “Bleb”の 形成がその要因の 1 つであろうということが提唱された. また我々は総頸動脈の一側にクランプをかけその末梢域の 頸動脈の内皮細胞表面に，走査電顕により Ballon-Crater 様構造と Bleb の形成の多発を見, 透過電䫓との相関で, 前者は giant vacuole, 後者は Majnos らののべた Bleb で あることをみとめた. 今回の報告は, 主として透過電顕に より,これらの構造上の解析とこれらの病理上の意義につ いて述べる.

実験方法：猿 18 頭を用い,一側総頸動脈に $30 \sim 2$ 時 間の Double Clampをかけ, 血流再開後, 直ちに左室より カニューレを㨂入し,グルタール酸灌流固定を行い, その後 オスミウム酸後固定を汇どこし, Double Clamp 内の対象
の一部は走査電顕用に, 一部は型のごとく脱水・包埋し透 過電影用とした。

結果：1. Blebには, Multivesicular type と Simple type の 2 種があり,両者の移行型が見出された. multivesicular type は, 主に血球で見られる multivesicular system と同じ型で, 数種の Vesicle を含み, 他の研究者の推 定のごとく分泌能に関連があると考えられた。 またSimple type は Majnos が脳内血管でみとめたものと同じ型であ り, ことに本実験では多発の傾向を示し, 周囲に Fibrin 様構造がみられ, 時に血小板の附着像がみられた。両 type とも, 内皮細胞の Intercellular Iunction に接続した内皮 絒胞内および Marginal Fold 部に多く形成され，いわゆ る Junctional Transport に何らからの関連のある病的構 造と考えられた. 2. Giant Vacuole の形成には, 1つは, 内皮細胞といわゆる Myointimal Cell (多くは平滑筋細胞) の接触面での, Myointimal cell の先端部の変性〜膨化さ らには Ghost Body 形成が, Grant Vacuole の形成に関与 しており, 他の 1 つは, 内皮細胞内の Digestive vacuole の巨大化と Autophagic Vacuole の巨大化が関与している 所見を得た。 以上述べた Bleb 形成は，広義の血管透過性 変化に対応した反応形式であり，さらにFibrin〜血小板の 粘着像から，血栓形成上に重要な意義があると考えられ る.

Giant Vacuole の形成に関与する Myointimal Cell の 上述の変化は, 血管の異物反応で多く観察され, 内皮下組 織に拈ける Myointimal Cell の変性と同じょらな変化で あり, いわゆる粥状硬化の初期要因として重要視されつつ ある。この意味で, クランプー血流遮断における Giant Vacuole の形成は, 逆に䊀状硬化成因 1 つとして重要であ ろ5.

3. Leucocyte Imigration は, クランブ側でも少数では あるが非クランプ側でもみられ，クランプによる一過性の 血圧下降による変化と考えられた。

\section{6. 動脈壁酸性多糖体の電子顕微鏡的研究}

\section{名大 第 3 内科}

葛谷文男 吉峯 徳 小林倫子 森 邦雄

従来より血管内皮細胞表面に，ある種の Heparin 様物質 が存在し血管障碍の防御機構に大きな役割を演じている事 が報告されている.今回はこれを電子顕微鏡的に確認する 目的で本研究を行なった。

実験方法 : 実験対象として幼弱ラットおよび幼弱家鬼お よび人の大動脈を用いた. 固定は型の如くグルタールアル デハイド並びにオスミューム酸で行なった。 また Reynold 法による $\mathrm{Pb}$ 染色をもあわせ行なった。 また Ruteninm Red による酸性多糖体の染色はグルタールアルデハイド固 定と同時に行なった. 
結果 : Ruteninm Redによって電子顕微鏡的に可染され て来る状態をまず in vitro でコンドロイチン硫酸 A並び にデキストラン硫酸によりたしかめた。すなわち Rutenium Red は両者と結合し不溶性の沈測物を作るがこれは極 めて electron deuse な粒子の塊となっている事がたしか められた。 ラットでは極めて厚いRuteninm Red 可染性 物質が内皮細胞表面に存在し，これはコンドロイチナーゼ A. B.C および Chondro-6-Snlfatase, Chondro-4-Sulfa. tase の混合液との incubation により幾分減少した。いず れにしても本物質注固定前の水染はもちろん, 固定后の水 染においても極めて消失しやすいものである事がわかった． すなわち Rutenium Red 染色は固定後では陽性率が極め て少なくなる。一方家兔では閉膜表面の本物質はラットに 比し少ない反面 Rutenium Red 可染性物質が内弾性板と 内皮細胞の間隙および内弾性板の中に多く認められ Rutenium Red 陽性物質のかかる部位における生理的意義の重 要性を暗示する所見を示した。 また人の大動脈では Rutenium Red 陽性物質は内膜表面に少なく, 七ンキ性肥厚を 示す部分では極めて多くの本可染性物質を認めた.

結論 : 1. 大動脈内膜表面に Rutenium Red 陽性物質 の存在を電子顕微鏡的に観察し確認した。

2. この物質は水に極めて溶けやすく, 水洗により容易 に流れ去る。

3. ラットと家鬼, 人の間で Rutenium Red 陽性物質 の量に差を認めた。すなわち

ラット>家鬼

ラット>人

といる結果を得た。これは脂質による動脈硬化若起の難易 と極めてよい相関がある事を示するのである.

4. コンドロイチナーゼ A. B. C 及びュンドロスルファ ターゼ処理により本物質の陽性率が若干変化した。

翼問：村田克己〈東大苑療内科〉

1. 動脈内層細胞表面に見出されたルテニウムレッド陽 性物質は細胞膜存在の可能性を示唆されたものであるかど らか.これとあわせ血流中よりの由来を考えておられるか， 内層細胞由来を考えておられるかをおきかせいただきたい．

2. コンドロイチナーゼ $\mathrm{ABC}$ 単独使用以外にコンドロ スルフアターゼを作用させる理由と差異.

答 : 葛谷文男

(1) 水洗で簡単に消失するという事実から膜の中にある ものではないと考えている。

(2) Rutenium Red 陽性物質が少なくなるという事はい えるが Electron Density の変化に関してはもう少し慎重 な検討を要すると思う。即ち切片の厚さの問題があるから である.

\section{7. 加齢ならびに耐糖能と血清ならびに尿の酸性ムコ多糖}

12 巻 2 号 $(1975: 3)$

\section{との関連について}

弘大 大池内科

黎明リハビリテーション病院

井沢和弘 金沢武道 吉田 稔 盛 英機 目時弘文

寺田俊夫 小松德弥 涉谷耕司 伊藤久夫 川島せつ 米田豊次 大池弥三郎

弘大 保健管理センター

松井哲郎

目的：われわれは，血清ならびに尿の総タンパク結合糖 と加龄ならびに醇糖能の良否との間に関連のあることを報 告してきた。 そこでこのたびは，総タンパク結合糖の中の 1つであって，従来動脈硬化血管壁に多量に存在している といわれている酸性ムコ多糖 (AMPS) と加齢ならびに耐 糖能との間の関係を追求した。

対象ならびに力法：1）対象は, 感染症, 悪性腫瘍, 膠 原病ならびに肝・腎の疾患を除外した 115 名である。

2）試料は早朝空腹時の血清ならびに24時間尿である.

3）AMPS の測定は木村らの方法に従い, AMPS 量は Galacturonic Acid を指標にして算出された.

4）年令は 40 藏末満，40～59 藏，60 以上の 3 群にわ けられた。

5）耐糖能の型の判定は， $100 \mathrm{~g}$ GTT を行ない. 日本 糖尿病学会の基準に従った.

結果：1）血清 AMPS は，老年になるにつれて低值で あり, また，耐糖能低下者では耐糖能正常者に比し高值の 傾向である。

2） 24 時間尿の AMPS の濃度ならびに量は，老年に なるにつれて低値であるが，耐糖能の良否との間には関連 がない.

3） 24 時間尿の AMPS 濃度 / 血清 AMPS 比は, 加 令ならびに耐糖能の良否との間には，関連がない。

4） 24 時間尿の AMPS 量／血清 AMPS 比は，耐糖 能低下者く耐糖能正常者であるが，加齢との間には関連が ない.

結語：1）加秢によって血清 AMPS および尿 AMPS は減少する，耐糖能の低下によって血清 AMPS は増加の 傾向であるが，尿 AMPS は増減しない。

2）したがって，加齢と耐糖能低下とは，ともに血管障 害的因子と考えられているけれども，血清と尿の AMPS の立場からみれば, この加龄と耐糖能低下とは，血管障害 に関与するも，異なった機序によるものであると考えられ る.

質問：村田克己〈東大物療内科〉

血清ムコ多糖量の分布範囲をかなり広く発表されている が，いかが怙考学か，尿中ムコ多症量はある程度の変動が あるが，血清中濃度はさして大でないと思う。

答 : 井沢和弘 
同検体を数回測定し，誤差は数パーセント以内であっ た.

\section{8.ヒト大動脈ムコ多糖と動脈硬化 一特にその生物活性 についてー}

東大 物療内科

飯塚健次郎 村田克已 中沢浩二 堀内淑彦

ヒト血管結合組織のムコ多糖（AGAG）には脂血症清澄 作用, 抗㠜固作用があることが報告されている。しかし, これらの生物活性は AGAG 全体として検討しており, そ の質的差異に関する検討は行なわれていない。これら大 動脈 AGAG 中のどの成分に生物活性があるかを検討する のが本実験の目的である。ヒトの大動脈を内層と外層に剥 離し, 別個に AGAG を抽出し各々の構成成分について Dowex I-X2 $\left(\mathrm{CI}^{-}\right)$カラム分画後, chondroitinases による 二糖鎖分析を行なうと共に Dowex にて分画した AGAG について部分 thromboplastin 時間に及ぼす効果について 検討した，方法）ヒトの大動脈會と外層に分け別個に 脱脂, pronase によるたん白消化， $\mathrm{NaOH}$ による $\beta$-elimination の後 10\% TCA に上り除たん白を行ない.さらに 4 倍量の ethanol を加えて AGAG を得た。ささらに DowexI-X2 $\left(\mathrm{Cl}^{-}\right)$カラムにて $\mathrm{NaCl}$ で段階的に溶出し各分画 についてウロン酸を測定した。透析による脱塩, 濃縮を行 ないAGAGを精製した。 chondroitinases 消化後の不飽 和二糖を酪酸・アンモ二ヤ溶液に上る炉紙泳動で分別し， その定性定量比較を行った。次に $1.25 \mathrm{M} \mathrm{NaCl}$ 溶出画分 $\mathrm{AGAG}$ と $1.75 \mathrm{M} \mathrm{NaCl}$ 溶出画分について部分 thromboplastin 時間に及洔す効果についてしらべた。すなわち家鬼 血漿飞活性 cepharoplastin を添加し $0.02 \mathrm{M} \mathrm{CaCl}_{2} \mathrm{AGAG}$ 溶液を加えて Fibrometer を作動し凝固時間を測定した。

結果：ヒト大動脈 AGAG には部分 thromboplastin 時 間延長効果があり, しか子濃度增加と共延長効果は增大 した。 すなわち内層 AGAG では chondroitin sulfate (CS) -rich の $1.75 \mathrm{M} \mathrm{NaCl}$ 画分が heparan sulfate(HS) -rich の $1.25 \mathrm{M} \mathrm{NaCl}$ 画分の活性を有意に上まわり, 外 層 AGAG では CS-rich の $1.75 \mathrm{M} \mathrm{NaCl}$ 酒分がHS-rich の $1.25 \mathrm{NaCl}$ 画分の活性を有意に上まわっていた。次に 1. $75 \mathrm{M} \mathrm{NaCl}$ 画分について活性をみると外層 $\mathrm{AGAG}$ が有 意に内層 $\mathrm{AGAG}$ を上まわり，1.25M NaCl 画分について も外層 $\mathrm{AGAG}$ が有意に内㬝 $\mathrm{AGAG}$ の活性を上まわった。 このような活性の相違は AGAG の構成成分のどのような 相異にもとずくかを検討した． Chondroitinases による二 糖鎖分析を行なったところ, 内膜 $1.25 \mathrm{M} \mathrm{NaCl}$ 画分には 総 AGAG に対し HS (chondroitinase で未分解の AGA G) が $85 \%$ で chondroitin 4-sulfate (C-4S), dermatan sulfate (DS), chondroitin 6-sulfate (C-6S) (不飽和二螗 より算出, 以下同様）が $2 \% ， 2 \% ， 5 \%$ であるに対し,
1. $75 \mathrm{M} \mathrm{NaCl}$ 分画には $\mathrm{HS}$ は $2 \%$ で C-4S, DS, C-6S が $26 \%, 19 \%, 46 \%$ であり, CS-rich の $1.75 \mathrm{M} \mathrm{NaCl}$ 画分に活性が高かった。外層に沶いては $1.25 \mathrm{M} \mathrm{NaCl}$ 画 分では HS が $79 \%, \mathrm{C}-4 \mathrm{~S}, \mathrm{DS}, \mathrm{C}-6 \mathrm{~S}$ が $2 \%, 1 \%, 7 \%$ に対し $1.75 \mathrm{M} \mathrm{NaCl}$ 画分では $\mathrm{HS}$ が $4 \%, \mathrm{C}-4 \mathrm{~S}, \mathrm{DS}$, C-6S が $20 \%, 24 \%, 42 \%$ であった. 外層 $1.75 \mathrm{M} \mathrm{NaCl}$ 画分の活性が内層 $1.75 \mathrm{M} \mathrm{NaCl}$ 画分の活性を上まわって いた理由は DS の活性が強いといら従来の私達の data り外層に DS の含量が多いためと考光られた．以上の結果 より動脈の抗凝固性の主体は HS よりもむしろ $3 \mathrm{CS}$ に, 中でも DS にあると考兄られた。

\section{9. 動脈硬化症に関する実験病理学的研究 IV 酳素局在と血管透過性について}

日医大 病理学教室

浅野伍朗 石神邦孝 山田展敬

各種動脈硬化症の発生に血管透過性え進の関与が重視さ れている。動脈硬化症発生の解明に血管に局在する各種醳 素の消長と血管透過機序との関連性を検索すべく以下の実 験を行なった。

材料および方法：成熟雄性家鬼（2-3kg）を用いて条件 別に I, 無処置対照群, II, 1 \%コレステロール負荷群 II, バゾプレッシン注射群（20 単位隔日 10 回投与), IV 1 \% 「コ」負荷十「バ」注射群の 4 群に分ち， 4, 5, 6 週間の観 察後, 屠殺前に tracer として Horseradish Peroxidase (10 $\mathrm{mg} / 100 \mathrm{~g})$, Fecin $(20 \mathrm{mg} / 100 \mathrm{~g})$ を耳静注 30 分後に屠殺, 大動脈, 中脳動脈を対象に対比検索を行なった. HPO の 観察には Graham-Karnonsky 固定液を使用, 3-3' diaminobentijine 含有の基質液に浸漬, その局在を観察, 同時 に各種酵素の局在は $1 \%$ ホルモールカルシウム液 (電顕), 電顕的には 4 \% パラホルムアムデヒド, $2.5 \%$ グルタール アルデヒド燐酸緩衝液を用いて固定後 ATPase (Wachste-

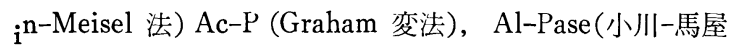
原法）LDH（Barka 法）の局在消長を検索した。

結果・形態的には「コ」負荷により大動脈内皮細胞は腫 大し, 嚥领空胞增加, 細胞間隌開大を示すのに比し脳動脈で は形態変化は軽微に止り軽度の燕领空胞增加のみで tight junction の開大は認められず, tracer の透過も大動脈に 比して著しく抑制されていることが知られた。一方「゙゙」 注射群では大動脈, 脳動脈で形態変化は強く, 内皮細胞内に 著しい空胞増加，リボゾーム減少，基底膜膨化おょび中膜 筋細胞において「コ」単独投与群に比し著明な空胞および cytosome 增加がみられ， tracer の透過状態からも「吉 投与が透過性を㐭進していることがうかがわれる．酵素化 学的には ATPase は大動脈内皮細胞の細胞膜, 睘飲空胞, 采粒体, 筋細胞の系粒体に脳動脈では基底膜, 燕领空胞に その活性局在を認めた。「コ」負荷，「バ」投与により活性 
$12: 96$ 日本老年医学会雑誌

増加をみるが障害増強に伴い減少を示す. Ac-Pase は内皮 細胞の lysosome，小胞体に活性をみるが条件群における foam cell 形成および cytosome の出現に伴い活性増加が みられ，透過性え進との間に相関がみられた。Al-Pase は 大動脈，脳動脈では活性は殆んどみられず，僅かに脳動脈 の基底膜の外層および中膜筋細胞の糸粒体に活性が認めら れ，脳における blood-brain barrier との関連性が示唆さ れていた。 Al-Pase は障害が強まり細胞の再生に伴い若干 の増加がみられた。 LDH は脳動脈では大動脈に比し活性 が強いが「コ」負荷，「バ」投与群ではこの時期においては 有意の消長はみられなかった。

結語：1）大動脈，脳動脈では形態的特徵との相関に拉 いて動脈硬化症発生に相異がみられた。 2) Horseradish Peroxidase, Fecin は条件群で透過性に差異を示しており 脳動脈において「バ」投与群で「コ」単独投与群に比し著 しい透過性立進に伴う強い形態化がみられた。 3) ATPase, Acid-Pase は細胞内での活性局在および条件群における活 性, 漖長より透過性との関連性が示唆されていた。

\section{答 : 浅野伍朝}

1. Al-Pase 活性は脳動脈基底膜外層に認められた。こ の局在はいわゆる blood-brain barrier の存在との関連性 に扣いて注目される。

2.「バ」投与群に技いて脳動脈壁に障害をみるが細胞 内の tracer は周囲の neuropil に比し少ないように思われ た.これは末梢血管の透過性え進を裏付けているかに思わ れる。

3. ATPase の活性局在は基質液の $\mathrm{pH}$ により異なると されている。我々は $\mathrm{pH} 7.4$ の基質液を使用した。

啠問 : 沼野藤夫〈東医歯大第 3 内科〉

(1) 脳血管内にもある程度 Ferritin などが入っていると の報告だが Vasopressinを何週間投与した群よりみとめら れたか。

(2) 大動脈内膜では mitchondria で, 脳大動脈では base ment membrane で Al-Pase 活性が上昇しているとのこと だが，これが透過性立進にどういう意味をもっていると揖 かんがえか.

(3) ATP についてはいかがか, $\mathrm{pH}$ はいくつだったか. 答 : 浅野伍朗

1. LDH 活性は血管透過とは直接関係ないようです. 今回の実験では条件群に打いて LDH の消長に有意の差は みられない.

2. 脳動脈に扮いて cytosome 増加に伴い Acid-P 活性 も増加して拈り，これは血管透過性亢進の機能的裏付けと して意義あるものと思われる。

40. 過反応性動脈内皮細胞の继状硬化好発部位出現亡 Cyclic AMP, Dibutyryl cyclic AMP, Pyridinol-
12巻 2 号 $(1975: 3)$

\section{carbamate, および Cyclic AMP phosphodies- terase inhibiton; EG 467, EG626 による抑制効果, およびその臨床応用}

東海大 動脈硬化研究所

島本多喜雄 小林正彦

東医歯大 第 3 内科

沼野藤夫 須永俊明 村瀬 弘 山崎博男

Pyridinolcarbamate (PDC) はヒトの弹状硬化の進行を止 め (Redischs 5, 1974), 粥状硬化性疾患に有効な事実が, 臨床薬理学的手法で日本・米・スエーデン・ソ聯等で知ら れてきた。即ち粥状硬化巣に直接作用する治療薬が医学史 上初に登場したことになった。

本研究の目的は, 张状硬化の成因や病像の多彩であるこ とにかんがみ，あたかも細菌疾患の抗生物質療法がペニシ リンによってその扉が開かれたと同様に，(PDC)で抗動脈 硬化症治療の道は開かれたが，さらにペニシリンに対する ストレプトマイシン等の如く, その多彩な粥状硬化症に対 応する新治療薬探求が第一の目的である。

我々は 1972 年動脈の内腔を蔽う内皮細胞がアドレナリ ン, アンヂオテンシン III, コレステロール $1 \mathrm{~g} / \mathrm{kg}$ 経口負 荷等で刺激興奮させられ，その結果強い収縮のみこみ活動 を行ならにいたり，血漿中の水を大量に壁中に入れて浮腫 性動脈反応を沶こす，血漿蛋白のうち $\gamma$-globulin，フィブ リノーゲン・ベータリポ蛋白 (LDL) も侵入する，その際 LDL は内弾性板にひつかかり一時停滞することを明らか にした。

本回はプレベーターリポ蛋白 (VLDL) に等しい大粒子 としてカーボン（ペリカンインクを生食水で倍にうすめ, 毎䏕 $5 \mathrm{ml}$ 静注）を用い, さらにアンヂオテンシン II を加 えて家鬼動脈内皮細胞を刺戟するとカーボン粒子 (CP) は 粥状巣好発部の $2 \sim 3 \%$ の内皮細胞によりて，(1)内皮細胞 のドン食に近い作用によって投与された CP は内皮細胞を 通り，(2)収縮のため開いた内皮細胞間間吵を通過して，内 皮下に入る。一旦入った CP の多くは内弾性板の通過は困 難で半永久に内皮下に止った.

この CP を通過させる動脈の内皮細胞が「過反応性」と 命名された。 それはその下の内弾性板に半永久にひつかか ってしまうよらな大粒子を通すにいたる故である。このよ らな動脈内皮細胞は生後 2 週の家鬼にはほとんど存在しな い. 年齢とともに増すが，主に大動脈冠脳頸動脈等で，小 型の動脈には無い、鵎にも同様．猿犬には大動脈にあるが その密度は前二者より少ない.ラットにはみとめられなか った.

高血圧ラット（SHRAT）で血圧 $190 \mathrm{mmHg}$ 前後のもの には密度はうすいが存在し, 脳底動脈のような細いものに もあった。

（2）血漿中の水や LDL 等の，上述のストレスによる内 
皮細胞の興奮による内皮下侵入が PDC で防がれると同様 に CP の内皮下侵入もかなり抑制された。 しかも PDCは cAMP 前駆物質 ATP を増すことから，別の方法で動脈 内皮細胞内 $\mathrm{cAMP}$ のの増加をはかってみた。すなおち $\mathrm{c}$ AMP 又はDBcAMP 投与, 又は $\mathrm{cAMPPDE}$ 抑制物質 $\mathrm{EG}$ 467, EG626 の投与である。これらは PDC 同様に浮腫性 動脈反応を抑制し，CP の侵入を著しく減少せしめた。

(3) EG467, EG626 はコレステロール負荷家鬼粥状硬化 を阻止する事実を確めた。

（4）それが直接細胞内の cAMP の cAMPPDF による生 理的破壊を抑制することいにより cAMP の細胞内レベル を上昇することから, 脳動脈硬化により精神神経機能の衰 えた高柃者 12 例及び同様に小脳失調症を伴った Late Cortical Cerebellar Atrophy 8 例, Olivopontocerebellar Atrophy (OPCA 3 例) 飞 OLIVO ONTEG6261 日 300mg を投与した結果, attentiveness の改善その他脳機能のかな りの改善を前群 12 例中 10 例にみとめ, 小脳群では全例 に運動言語書字の改善をみ, とくに発病后 1 年 5 年の例 中著効を示すもの 3 例に及んだ. OPCA 3 例中 2 例に唾 液分泌卉進著しく，1例は夜回頻尿と放尿に時間がかかっ た (Spastic Bladder) が, 投薬第 3 日以後正常となった。

\section{1. 正常家鬼および実験的糊状硬化家鬼と Prostaglandin $\mathrm{E}_{1}\left(\mathrm{PGE}_{1}\right)$}

日大 第 2 内科

駿河台日大病院 循環器科

鈴木 忠 增㴊和夫 横山 登 伊藤雅夫 西野憲史 八木 洋 小池昭夫 室田 直 佐藤喜彦 梶原長雄 波多野道信

目的 : PGE は, 血圧下降や脂質の変動を来たす事が知 られて来たが我々は䋆状硬化家鬼を作製し, 正常家鬼との PGE 作用を比較検討した.

実験材料および方法：ラノリン飼料飼育 $12 \sim 16$ 週家鬼 をA 群, $1.5 \mathrm{~kg} \sim 2.0 \mathrm{~kg}$ 幼若家鬼を N群とし, 各群とも大 腿動脈の一側は多目的監視装置で血圧を描記, 他側はカテ ーテルを胸部大動脈をで，插入しその部より $0.28 / \mathrm{kg} の$ PGE を一分間で注入し, 経時的に採血, 実験に供した.

結果：血圧は $\mathrm{N}$ 群, A 群共注入中 $10 \mathrm{mmHg}$ 以内の下降 を示し, 注入終了と同時に回復し， 5 分後には, ほぼ前值 に復した。 血圧下降は $\mathrm{N}$ 群平均 $5 \mathrm{mmHg}, \mathrm{A}$ 群 $8.8 \mathrm{mmHg}$ とA群により強く認めた. NEFAは, N群, A 群共注入終 了后 1 分で最位值を示し, 5 分後では, ほぼ前佔に復し, 以后減少傾向を示した。 N群の一分後の減少は危険率 $5 \%$ 以内で有意差を認めた。A群では減少は強いが，ばらつき があり, 有意の差を認めなかった. カテューラミン (CA) はA 群では 1 分後より上昇傾向を示し 5 分後には, ほぼ前 值に復した， N群では著変は認めなかった。 カルミウム
（Ca）はN群，A群とも著変は認めなかった.

考案 : Bergstrom による Prostaglandin のホルモン様作 用の示唆以来, PGE の脂肪織からの NEFA グリセロール の放出抑制作用の強い事が明らかとなって来た。しかし in vivoに打いては in vitroに护ける様には一様でなく， 種族の違い，あるいは，PGE，濃度により異なった態度を とる事が報告されている。その因子として生体内臓器組織 の感受性の問題, 血生の変動を含めた $\mathrm{CA}$, その他ホルモ ンによる影響, 食䬣状態, 他蔵器への取り込みの問題等が考 えられている。 Carlson らは非麻酔犬で $0.28 / \mathrm{kg} / \mathrm{min} の$ 持続注入法で NEFA の上昇, $0.48 / \mathrm{kg} / \mathrm{min}$ 以上では低下 を示す事を述べている. 一方人体に拈いても 0.056 ～ 0.32 $r / \mathrm{kg} / \mathrm{min}$ の持続注入 30 分施行では NEFA の上昇をみ ている，我々の一回注入法による実験結果ではN群で 0.2 8/ kg/min で明らかに NEFA は低下しており，血圧の変 動，CA の動きも著しくない，一方A群における注入后の 動きは，ばらつきがあり有意差を認めなかった。これらの 血圧, $\mathrm{CA}$ の変動をみると，N群に比し血圧では下降傾向 強く $\mathrm{CA}$ も 1 分, 3 分で上昇傾向を又る。この事は $\mathrm{A}$ 群に おける脂肪織への脂質のプールの増大，血管壁への脂質沈 着に対する PGE の感受性の問題等の他, 脂質沈着により 障害された血管壁への PGE の反応の変化，血圧低下その 他の因子によりひき起こされる CA をはじめとするホル モンの影響等が考えられる。 また生体内の脂質低下を単に 脂肪織よりの放出抑制のみならず取り込みも考慮している 報告もあり複雑な要困がからみあっているものと考えられ る.

結語：䋆状硬化家鬼および正常家鬼を使用し，次の結果 を得た. PGE $0.2 \gamma / \mathrm{kg} / \mathrm{min}$ 投与により両群共 NEFA の 低下をみたが正常群では $5 \%$ 以内の危険率で一分后の低下 に有意差をみた。粥状硬化家鬼では正常群に比し血圧の低 下傾向が大で且つカテューラミンの上昇傾向をみた.

\section{2. 大動脈壁の脂質分解酵素について（第 2 報）} -Cholesterol Ester Hydrolase の純化について都養育院付属病院

桜田豊三 折茂 肇 岡部紘明 野間昭夫 村上元孝 都監察医務院

越永重四郎

粥状動脈硬化症に颃いて, 動脈内膜にエステル型コレス テロール (CH. E) が異常に沈着することから，これを水 解するコレステロール・エステル・ハイドロラーゼ (CH. E. H) の役割が重要であると考えられている. しかし大動 脈壁でのこの酵素の活性は非常に弱いために，その性質は ほとんど明らかにされていない.今回はこの CH.E.H の 性質を知るために，まず酵素の純化を試みたので報告す る. 
CH. E. H の測定は $0.05 \mathrm{ml}$ の $0.01 \mathrm{M}$ 燐酸緩衝液（pH

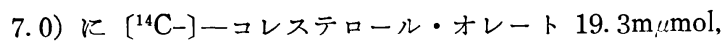
タウロコール酸ナトリウム $38.6 \mathrm{~m} \mu \mathrm{mol}$ および大豆レシチ ン $59.7 \mathrm{~m} \mu \mathrm{mol}$ を加えて超音波処理したものを基質液と し, これに至適 $\mathrm{pH}$ に調整するための緩衝液 (0.5M) 0 . $05 \mathrm{~m} l$ および酵素液 $0.4 \mathrm{~m} l$ を加えて， $37^{\circ} \mathrm{C}, 4$ 時間イン クベートした. 反応終了後へキサン・エーテル・エタノー ル（1:1:1）の溶媒で脂質を抽出した. TLCにて遊離コ レステロールと $\mathrm{CH} . \mathrm{E}$ を分離し，打の括のの放射能を測 定し，その比率から CH.E.H 活性を求めた.

死後 10 時間以内の成人大動脈を剖検により得て, 肉眼 的に正常と思われる部分を，内膜と中膜に分け，常法のご とくアセトン粉末を作成した.アセトン粉末 $1 \mathrm{~g}$ に対し 0.01M の燐酸緩衝液（pH7.0）を $20 \mathrm{~m} l$ を加之て, ホモ ジナイズし，20000xg，10分間遠心した。.この上清をセフ アデックス G75 $(2.6 \times 100 \mathrm{~cm})$ を用い， $0.1 \mathrm{M}$ の塩化ナ イリウムを含む $0.01 \mathrm{M}$ の燐酸緩衝液（pH7.0） で溶出し た.

セファデックス G75 にて溶出した時の蛋白質のバター ン (O.D 280m $u$ ) は, 大半がボイド・ボリューム直後に 認められた. CH.E.H 活性は，それよりやや遅くれて溶 出された。 以上の操作により, 大部分の不要な蛋白質と CH.E.H が分離され, 内膜ではアセトン粉末の 80.4 倍, 中膜では 100.5 倍に比活性は上昇した.この部分的に純 化された酵素液の全活性は, 初めのアセトン粉末の全活性 に比し, 約 8 倍上昇していた。

この全活性の上昇をさらに追究するために，部分的に純 化された酵素液に，セファデックス G75 カラムで溶出さ れた活性ピークの前後のフラクションの溶液を加えて, 酵 素活性の測定を行なった，活性のあるピークの前のフラク ションを加えたものが, 酵素活性を, 内膜で $34.3 \%$, 中 膜では $50 \%$ 抑制した。 しかし，活性ピークの後のフラク ションを加えたものでは，活性に影響を与えなかった。

以上のことから，大動脈壁中に， CH.E.H 活性を抑制 する因子が存在することが認められ，この抑制思子はセフ ァデックス G75 にて溶出することにより，取り除くこと が可能であった. 又この抑制因子が CH.E.H 活性に大き く影響することから，動脈硬化症の発生あるいは進展に際 して，何か影響を和よぼしていることが推測された。

\section{3. 大動脈壁の脂質分解酵素について（第 3 報） -Cholesterol Ester Hydrolase の性質について一} 都養育院付属病院

折茂 肇 桜国豊三 岡部紘明 野聞昭夫 村上元孝 都監察医務院

越永重四郎

第 2 報に括いて述べた方法で部分的に純化了ーた大動脈壁
12 巻 2 号 $(1975: 3)$

コレスロール・エステル・ハイドロラーゼ (CH.E.H) 標 品を用いて，その性質についての検討を行なった。

まず, この酵素の至適 $\mathrm{pH}$ は, 内膜, 中膜とも 2 つのピ 一クが認められ, 酸性側のものでは, 内膜中膜とも $\mathrm{pH} 5.0$, 中性側のものでは, 内膜は $\mathrm{pH} 7.0$, 中膜では $\mathrm{pH} 7.5$ にピ 一クが認められた。インクベーション時間による影響は, 内膜に扔いては， 6 時間目まで直線的に上昇した。 中膜で は，8時間目までゆるやかな曲線を抽きながら上昇した。

次に基質濃度に上る酵素活性の影響をみた。基質である コレステロール・オレート（CH.O） のみを増加させた場 合, 内膜, 中膜之も $38.6 \mathrm{~m} \mu \mathrm{mol}$ 以上より, 酵素活性は抑 制された。 また基質を作成する時に加える，レシチン，タ ウロコール酸を CH.O と等 mol で増加させた場合にも, CH. O の量で $38.6 \mathrm{~m} \mu \mathrm{mol}$ で醅素活性はピークに達した. この酵素活性の抑制をみるため, オレイン酸あるいは遊離 コレステロールを反応系に加えて, 活性を測定してみると 内膜中膜とも酸性側のものが著明に活性を抑制された。一 方中性側のものでは, レシチン括よびタウロコール酸の濃 度により活性は強く影響され，これらの濃度の上昇ととも に，酵素活性は低下した，以上のことょり，大動脈壁の CH.E. H は基質の濃度の増加によって，活性は著しく抑 制され，さらにその反応成生物によっても活性は抑制され た。 また大動脈 CH.E.H の性質は, 内膜中膜の部位的な 違いよりも, 至適 $\mathrm{pH}$ の違いによる差の方が明らかであ った。

次に CH. E. H 活性に拈よぼす基質の形の違いによる変 化をみた。 タウロコール酸, レシチンおよびフルブミン を, おの扮の単独で $\mathrm{CH}$. O 超音波処理して基質を作成 した時の酵素活性よりも,レシチンにタウロコール酸ある いはアルブミンを加えて作成した基質を使用した時の方が 高い活性が得られた。しかしタウロコール酸とアルブミン で作成した基質では，おの括のを単独で作成した基質を用 いた時と同程度の活性しか示さなかった，CH. E. H を測 定するには，レシチンを必要とするが，レシチン単独で は，その界面活性作用は不充分であった。

以上の成績より, 䋆状動脈硬化病中のエステル型コレス テロールの著明な増加と考光合せて， CH.E.H が基質で ある, エステル型コレステロールの増加とともに活性が低 下し，その蓄積を加速度的に増加させているものと考兄ら れる.

また生体内での燐脂質の役割は不明な点が多いが，大動 脈壁での CH.E.H 活性に打よぼす作用についてみると, エステル型コレステロールと適度な割合で存在することに より, CH. E. H 活性を高めていることが示唆される.

\section{4. ビタミン $\mathrm{C}$ 欠乏による動脈硬化症の研究 一とくに副腎機能の変化について一}




\section{名市大 第 1 内科}

中野佐上 千田勝二 中山広一 樋口札治 林 勝彦 佐久問長彦 岡戸洪太 藤浪隆夫

C 欠乏食飼育による慢性 C 欠乏モルモットの大動脈内膜 および中膜に動脈硬化性变化の出現がみられた。この病変 は組織学的に Catecholamine (以下 CA) 投与により惹起 される動脈硬化症に類似すること, 拈よびCが副婜内に大 量に含有され，CA やsteroid hormone の産生に関与する と考えられていることから，C欠乏による動脈硬化症の発 生機序に拈ける副腎の役割について検討した。

モルモットをクレア社製 C欠乏食で 2 ないし 8 週間飼育 し, 副腎総 $\mathrm{CA}$ 量 (Lund 法), 尿中 $\mathrm{CA}$ 量 (Bio Rad社 カラム法), 尿中 VMA (Pisano 法), 血中 Cortisol (Peterson 法), 尿中 $170 \mathrm{HCS}$ (Rappaport 法), 17KS (Kornel 法）および大動脈ムコ多糖類（Bitter-Mier の変法）を测 定した。

1. C欠乏により副腎重量は対照に比べて有意に增大し, 組織学的には束状層の肥厚がみられた。副腎内 C 量は次第 に減少し，飼育 8 週では有意の低值を示した。

2. 副腎内総 $\mathrm{CA}$ 量は対照と有意の差を認めず，尿中 $\mathrm{CA}$ 量は減少の傾向がみられたが，VMA 量には差を認め なかった。

3. 血中 Cortisol 量は飼育第 4 週で有意の 増加がみら れ，第 8 週では逆に $2 \%$ 以下の危険率で有意の減少がみ られた．尿中 $17 \mathrm{OHCS}, 17 \mathrm{KS}$ む飼育 4 週で有意の増加が みられ，第 8 週でも低下の傾向がみられたが，対照に比べ てな怙高值であった，副腎内 cholesterol 量はC久乏第 8 週で著るしく増加し, cholesterol よりの steroid hormone 産生の低下を示すと考える.

4. 血清脂質は飼育 2 ないし 4 週に triglyceride の有 意の増加がみられ, choleslerol も対照に比べてや〉高值を 示した. 肉眼的な動脈硬化症の発症は飼育第 4 週で $17 \%$ に, 第 8 週で $65 \%$ にみられた. 大動脈ムコ多糖類含量は 肉眼的病変のみられない飼育第 4 週のC欠乏モルモット大 動脈にも有意の増加がみられた。

C欠乏時に CA の産生, 分泌の増加はみられず, C欠 そによる動脈硬化の発症機序に CA は余り関与しないと 考える.C欠乏 4 過をでは steroid hormone の分泌元進 がみられたが，この時期にみられた血清 triglyceride の增 加は steroid hormone 投与時の血清脂質の变化と類似寸 る.また, 大動脈のムコ多糖類の増加は Wexler が Gluc. ocorticoid の増加時にみられた大動脈のムコ多糖類が増加 したとの報告と一致する。副腎皮質ホルモンが脂質代謝や ムコ多糖類などの結合織代謝を介して動脈硬化の発症に何 らかの意義をもつものと考える.

質問 : 䓪谷文男〈名大第 3 内科〉

ビタミンCは Dopamin $\beta$ Hydroxylase の Cofactor と
なっている事が知られているがこの観点からビタミンC欠 乏動物におけるカテコールアミンに関するデーターをどう 意味づけられるか.

答: 中野佐上

カテュールアミン作成系の酵素活性は測定していないが， 今回の実験条件は非顕性のC欠乏状態で, この場合にカテ コールアミンの産生は強い抑制を受けていないと考える.

\section{5. 動脈硬化予防，治療に関する研究一Estrogen (E) お よび Progesteron（P）の動脈壁代謝に及ぼす影響に ついて〜.}

東医歯大 第 3 内科

沼野藤夫 相良淳史 勝 健一 黒岩トモェ

守家欽也 島本多喜雄

性 Hormone の動脈壁への影響は老化，動脈硬化症と関 邀して興味深い，女性は男性に比し平均寿命が長いことは 各国に共通してみられる。現象であり，このことから女性 Hormone 特に Estrogen の抗動脈硬化作用はよく知られて いる。しかしその作用機序は未に不明である。我々は先に Cholesterol 負荷家鬼はおいて Estrogen (Premarine) は有 意に大動脈 Fatty Streak 形成を阻止するが. Progesterone (chlormazinone acetate)には予防作用ないこと．組織化学 的検索で特に解糖系代謝が大動脈壁で前者でかなり低下し て扣り, 大量 Estrogen 投与では中膜筋細胞の萎縮消失壊 死が認められること. Progesterone 群ではか子る変化はみ られず. Estrogen と Progesterone 交代投与に予防効果を 示しながらも代謝面の抑制も強くない事実を確認報告した。 そこで動脈壁の湯における酵素活性への Estrogen および Progesterone の影響を in Vitro で確めた.

方法：骨肉腫のため死亡した 17 藏少女の大腿動脈片を 使用し Lowry の徵量酵素定量法を応用して, 解糖系 Key enzyme である Phosphofructokinase (PFK) 活性に及 ぼす影響を Estrogen (Premarin), Progesterone (chlorm. azinone acetate) 各濃度最終濃度で $50,100,200,400$ $\gamma / \mathrm{m} l$ reagent mixture) において比較検討を行なった。（方 法の詳細は Mech. Ageing \& Develop 2:43〜53, 1973). さらに血管内膜抢よび中膜の malic Dehydrogenose (MDH) 活性につき Estrogen $(4,8,16,32,64,128,250 \gamma / \mathrm{ml})$ の影 響を調べた。

結果 : $50 \gamma, 100 \gamma / \mathrm{ml}$ 濃度の Estrogen を混在 incubate することにより動脈壁 PFK 活性は Premarin 溶解液のみ の対照（1.386士0.107moles NAD perkgperh）に比し有意 の低值を示した。 $(0.143 \pm 0.030,0.285 \pm 0.022)$. 一方 Progesteron 群では 50,100,200,400 $/ \mathrm{m} l$ のいずれも対照 (0.894士0.036) (Progesterone は混油性のため少量の Propyrene glycol が混在) に比し有意の变化を示さなかっ た. 一方 $\mathrm{MDH}$ 活性は中膜では $64 \mathrm{r} / \mathrm{m} l$ 以上の濃度で活 
$12: 100$

\section{日本老年医学会雑誌}

性の有意の低值を示すのに対し内膜では $32 \gamma / \mathrm{m} l$ 以上で有 意の低值を示した.

考案および結論：上記の結果から Estrogen は先に組織 化学的に観察した in Vivo の場合と同様な結果を示し Estrogen の動脈壁解糖代謝に及ぼす影響の方向が示唆さ れた。

そしてこの事実が Estrogen の抗動脈硬化作用機序との 関連において興味深い. Estrogenの Angiotensine, Adrenaline, Stress による血管透過性元進阻止作用は極めて強 く, これが抗動脈硬化作用機序として注目されているが, 一力大量投与は中膜萎縮, 壞死等の催動脈硬化作用を示す. これに関し intima 及び media における活性抑制の差が 関心をひく，この差が抗動脈硬化作用の目的のための経過 濃度の存在と示唆しているのかも知れない.

一方 Progesterone には PFK に関する限りなんらの影 響を及ぼしていないことは Estrogen と Progesterone の 拮抗作用は他の場所にて求めるべきであることを示してい る.

\section{質問 : 葛谷文男〈名大第 3 内科〉}

Estrogen 系のものが Vitamin $B_{6}$ Enzym の強い inhi. bitionをする事が報告され，われわれもすでに報告してい るが, Estrogen 系物質の大量が動脈硬化性病変の悪化因子

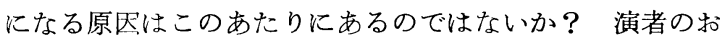
考えを持聞きしたい。

答 : 沼野藤夫

(1) Estrogen 分画による差や, 解糖系, TCA Cycle 系 以外の酵素についての定量的な研究には未だ手がつけてい ない，たた，解糖系代謝ときわめて密接な関係がある $\mathrm{Cy}$ clic AMP, Cyclic AMP Phosphodiesterase についての研 究は始めているが Estrogen のある濃度では Cyclic AM. PPDE 活性の低下と Cyclic AMP の増加を来たす場合が あるようである. 今後さらにこのPoint が動脈硬化予防作 用に関連めるかどらか, 解糖系酵素活性への影響と比し検 討してゆきたいと思う。

\section{6. 人動脈硬化における Transglutaminase 活性および Factor XIII.}

\section{名大 第 3 内科}

吉峯 德 葛谷文男 小林倫子 森 邦雄

動脈硬化発生の一成因として, 血管内壁障害により, 血 管内腔表面に血栓を生じ, これから動脈硬化が形成·進展 すると考えるとき，フィブリノーゲンーフィブリンに働く 酵素として，トロンビン及び Factor XIII が知られている. この Factor XIII および Transglutaminase が動脈壁中に 存在する事が報告されているが, 我々も今回人大動脈壁で の酵素活性について動脈硬化との関連性について検索し た.
12巻 2 号 $(1975: 3)$

実験材料および方法：大動脈は事故死により剖検され た 6 例を用い, 出来る限り死後 15 時間以内のものを使用 した. 肉眼的に硬化度 $0 \sim 4$ に分類し, 大動脈弓部, 胸部 大動脈および膜部大動脈の各部位で内一中膜切片を使用し た. Factor XIII 測定にはパルチゲン法を使用した。すな わち 1.5\% Agarose 液を用い. Anti-Factor XIII Subunit A Serum (Anti-A) および Anti-Factor XIII Subunit S Serum (Anti-S) のそれぞれ 2 種類について孔径 $3 \mathrm{~mm}$ の穴 12 を有するプレートを作成した. 大動脈は生食水

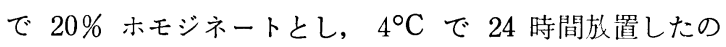
ち, その $40 \mu$ を使用, 48 時間後にリングの直経を测定し た.

Transglutaminase 活性の測定には，10\% ホモジネート を使用し，Casein を基質とする Dvilansky，A. らの方法 に準じて行なった.

結果：a）パルチゲン法による Factor XIII Anti-A につ いてのリング直径の平均は, 大動脈弓部 $7.8 \mathrm{~mm}$, 胸部大 動脈 $5.18 \mathrm{~mm}$, 腹部大動脈 $5.2 \mathrm{~mm}$ の拡がりを示し, 硬化 $0 \sim 3$ までの間に差異なく, 硬化 4 では反応なしを示した. Anti-S についても, 弓部 $5.6 \mathrm{~mm}$, 胸部 $5.4 \mathrm{~mm}$, 腹部 $5.5 \mathrm{~mm}$ の平均を示したが，硬化 4 では 0 であった。

6) Transglutaminase 活性

硬化 0 〜 のらち 0 〜 度ではほとんど差異のない活性 を得たが, 硬化 4 では活性 0 を示した. 活性度は対照とし た肝に比して低值を示した。

考案 : 今回の検索で我々は人大動脈壁中に Factor XIII および Transglutaminase 活性を認めたが, 動脈硬化の程 度との相関については, 例数の関係上特に差異を認めなか ったが，硬化 4 については活性を失なっていた，即ち動脈 硬化の或時期までは, 酵素活性が保たれており, 動脈壁と 血管内成分との平衡に何かの役割りを示すものと考えられ る. 更に例数を増して詳細を検討する予定である.

\section{7. エラスターゼ活性に関する研究}

\section{I. ヒト血清エラスターゼ活性の動向}

東大 老年病

金 玟全 藤田拓男 大畑雅洋 吉川政己

固型の線維蛋白であるエラスチンは動脈壁, 肺, 皮虐等 に広く分布し, 加令との関係が認められている. 特に動脈 壁エラスチンは乾燥脱脂動脈重量の $20 \sim 40 \%$ を占めその 変性過程が動脈硬化症の発症抏よび進展に重要な意義を有 することが明らかにされつつある．そこで私達はエラスチ ンの代謝をらかがう一っの側面としてェラスチンを特異的 に分解する酵素であるエラスターゼ活性の動向をヒト血清 に执いて検討した．測定方法はウシ Lig. nuchae よりア ルカリ処理で精製しアミノ酸組成の分析よりその純度を確 認したェラスチンに Chloramine $\mathrm{T}$ 法にならい ${ }^{125} \mathrm{I}$ を標 
識したものを基質として, 反応後ろ過し溶液相に移行した 放射活性を測定することによりェラスターゼ活性をみた。 な拈精製膵エラスターゼ標品をスタンダードとし，エラス チン $1 \mathrm{mg}$ を $37^{\circ} \mathrm{C}, e 0$ 分のインキニベートで分解する醅 素量を1E.Uとして表示した。 反応系は 0.1M Tris bufier（pH8.6）中で行なわれた.

成績：(1) 精製膵エラスターゼ標品を用いてその Dose response をみるとエラスターゼ $0.5 \mu \mathrm{g}$ の微量をで測定可 能であり $5 \mu \mathrm{g}$ まで活性の間に直線関係を示す。この Radioassay 法ではコンゴレッド色素標識エラスチンを基質と する比色法に比し約 40 倍に感度が上昇している. (2) 反 応系への血清添加量は $50 \mu l$ までは活性の間に直線がみら れるが，それ以上では漸次プラトーとなる。そと理由の詳 細は不明であるが $50 \mu l$ の血清添加で血清ェラスターゼ活 性の測定が可能である。（3) 73 人の健常人血清エラスタ 一ゼ活性は平均值 $0.82 \mathrm{E} . \mathrm{U} / \mathrm{m} l$ であり, 男 38 人では $0.82 \mathrm{E} . \mathrm{U} / \mathrm{m} l$, 女 35 人では $0.83 \mathrm{E} . \mathrm{U} / \mathrm{m} l$ と特に性差を 認めない. (4) 加令の影響をみると 20 代で 1.55 E.U/ $\mathrm{m} l$, とピークとなり以后加令とともに漸減 し, 50 代で $0.55 \mathrm{E} . \mathrm{U} / \mathrm{m} l, 60$ 代で $0.66 \mathrm{E} . \mathrm{U} / \mathrm{m} l$ と 20 代の約 $1 / 2$ 以 下に低下している。 (5) 血清ェラスターゼ活性と加令の関 係を性別にみたが，特に有意の差は認められなかった。 (6) 血清エラスターゼ活性と血清コレステロール值との相関を 検討してみると 40 歳以下では有意の相関を認めないが, 40 歳以上では, $\mathrm{r}=0.6 \mathrm{p}<0.001$ と有意の正相関がみら れた. (7) 動脈硬化症患者之して陳旧性の心筋硬塞症 4 名 脳血栓症（片麻痻） 3 名計 7 名の血清エラスターゼ活性は 平均值 $0.31 \mathrm{E} . \mathrm{U} / \mathrm{m} l$ であり, 年龄を対応させた健常人 17 名の平均值 $0.59 \mathrm{E} . \mathrm{U} / \mathrm{m} l$ に比し低下して和りその差は有 意であった。

結論 : 加踰動脈硬化症での低下コレステロールとの相関 は, 動脈硬化症と何等かの関係を示唆するものであるが, なおその評価は今後の検討を要する。

\section{8. エラスターゼ活性に関する研究}

\section{II 高コレステロール食飼育家鬼の血清及び組織（大 動脈, 肺, 膵) エラスターセ活性の動向}

\section{東大 老年病}

金 玟全 藤田拓男 大畑雅洋 吉川政已

ヒトに拈ける血清エラスターゼ活性と血清コレステロー ルとの相関をさらに組織レベルまで含め検討するため, 家 鬼を用いて実験した．正常食群と $2 \%$ コレステロール食 群に分けコレステロール群では $1,2,4,8$ 週に採血, 血 清を分離しまた $2 ， 4,8$ 週に大動脈, 肺, 脺を採取し, これを $0^{\circ} \mathrm{C}, 0.9 \% \mathrm{NaCl}$ 溶液で脱血洗浄しさらに $0.1 \mathrm{M}$ 'T ris buffer で洗浄し, 大動脈では外膜をはく離除去する. 組織を細片化後, Tris buffer 中で Waring blender で homogenize 後 $10,000 \mathrm{~kg} 20$ 分間の $0^{\circ} \mathrm{CF}$, 遠沈により 上清を分離し，酵素液とした。組織エラスターゼ活性の測 定は血清と同様 ${ }^{125}$ I-標識エラスチンを基質とする Radioas. say 法によった。

成績 : (1) 家鬼の血清エラスターゼ活性に及ぼすコレス テルール食の影響をみると正常食群 $0.46 \mathrm{E} . \mathrm{U} / \mathrm{m} l$ に対し, 1 週めですでに $0.75 \mathrm{E} . \mathrm{U} / \mathrm{m} l$ と活性の上昇がみられ， 2 週めで $1.32 \mathrm{E} . \mathrm{U} / \mathrm{ml}, \quad 4$ 週めで $1.18 \mathrm{E} . \mathrm{U} / \mathrm{m} l$ と增加し, 正常食群の 2 倍以上に上昇, その差は有意である. しかし, 8 週めでは $0.73 \mathrm{E} . \mathrm{U} / \mathrm{m} l$ と低下し, 正常食との間に有意 の差を認めない。(2) 大動脈のエラスターゼ活性は血清エ ラスターゼ活性と同様のパターンを示し， 2 週め 4 週めで 有意の上昇を示し，8週めでは正常食のレベルに低下する. (3) 肺ェラスターゼ活性はコレステロール食群です， 2, 4,8 週とも正常食群との間に有意の差を認めない. (4) 膆 エラスターゼ活性は 2 週めで有意に上昇する。しかし，血 清及び大動脈上り早く低下傾向がみられ，4週めで正常住 群と差がなく，8週めでも同レベルを維持している．(5) 大動脈及び膵のエラスターゼ活性は組織の湿重量及び上清 中の蛋白量あたりとして表現したが, 両者とも同様のパタ ーンを示した. (6) 家鬼を絶食させると 48 時間で血清エ ラスターゼ活性はわずかに低下するが，96 時間では著明 な低下がみられ食飭再摂取により 3 時間でわずかの上昇, 48 時間で前值に回復する.

結論 : 血清および大動脈のエラスターゼ活性がコレステロ 一ル食により上昇することは, 膵での酵素誘導及び分泌增 加を反映するものと考壳られる。

血清掞よび大動脈エラスターゼ活性がヒト血清エラスタ 一ゼ活性と同様, コレステロールとの相関がみられること は, 動脈硬化症の発症進展に, エラスターゼがェラスチン 代謝を介して何等かの作用を果たしらる可能性を示唆して いる. 動脈硬化が完成してくる8週めではエラスターゼ活 性が低下してくる事実は，ヒト血清エラスターゼ活性の成 績に類似しており, 動脈硬化症の発症進展期と完成期の差 を示唆するるのと考兄られる。

啠問 : 村田克已〈東大物療内科〉

1. 加跘ならびに動脈硬化患者血清エラスターゼ值の低 下について血清中の factor とくに inhibitor について検 討されたか. また，その関与が考兄られるか。

2. 血清エラスターゼの origin について

動脈壁中の值が比較的高いといら結果と血清レベル值と の相関をいかに解決しておられるか.

答: 金 玟全

血清エラスターゼは至適 $\mathrm{pH}, \mathrm{DFP}$ 及び $\mathrm{NaCl}$ とよる 抑:制，Trasylal により抑制されないことおよび熱処理に 対する態度より,さらには食䬣の影響を受けやすい等よ り, 膵 Origin の可能性が強いものと考えられる. 


\section{9. 脂肪, 糖質負荷による血清脂質と凝固線溶系の变動} 兵庫県立淡路病院

吉田 睦 松永公雄 石浜義民 松尾武文

神大 第 1 内科

福崎 恒 友松達弥

食餌組成の差異による，糖質打よび脂質代謝と血液凝固 に扣よぼす变化を知る目的で糖質負荷と脂肪負荷を行な い, 両者の病態生理を比較検討した。

対象および方法：入院中の糖尿病患者 22 例を対象とし て，早期空腹時に $25 \%$ の生クリーム $100 \mathrm{~g}$ を投与し，投 与 1 時間と 3 時間後に採血を行ない. 総脂質, 中性脂肪, 遊離脂肪酸血糖， IRI（二抗体法）と血漿フィブリノーゲ ン，トイグロブリン溶解時間（以下 ELT と略）を測定し た. 1 週間後に脂肪と等カロリ一の糖質食を投与し，脂肪 負荷の場合と同様の検査を実施し，両者の検査結果を比較 検討した。

結果：（1）血糖は糖尿病患者で糖質負荷で負荷後 1 時間 3 時間とも著明に上昇した，脂肪負荷では糖㽷病患者，血 管合併症を有する糖尿病とも負荷 1 時間， 3 時間後で軽度 の低下をみとめた.

（2）中性脂肪は脂肪負荷で糖尿病患者にて負荷 1 時間, 3 時間と次第に増加をみとめたが糖質負荷では負荷後 1 時 間で軽度増加， 3 時間では前值にもどっていた。

（3）遊離脂肪酸は糖尿病患者及び血管合併症を有する群 では糖質負荷で負荷後 1 時間, 3 時間とも著明に低下して いた． 3 時間後の低下は前值に比して有意であった．脂肪 負荷では糖尿病患者拉よび血管合併症を有する群とも変動 をみとめなかった。

（4） IRI 分泌は糖尿病患者では脂肪負荷に比較して糖質 負荷で負荷後 3 時間で分泌が大であった，血管合併症のあ る糖尿病では糖質負荷と脂肪負荷ではインスリン分泌に差 がなく，とくに糖質負荷による分泌反応の低下が著明であ った。 また脂肪負荷でも血管合併症例でのインスリン反応 は合併症のない糖尿病に比較して低下していた。

（5）血漿フィブリノーゲンは脂肪負荷・糖質負荷にて有 意の変化を示さなかった。

オイグロブリン溶解時間は糖尿病患者で糖質負荷 脂肪 負荷のいずれもELT は短縮していた。 しかし負荷 1 時間 後では脂肪負荷による ELT は短縮がみられず, 糖質負荷 の場合はすべて短縮していた。

結論：糖尿病患者で糖質負荷, 脂肪負荷を行ない糖質負 荷で血糖の上昇，遊離脂肪酸の低下を認め，一方，脂肪負 荷では中性脂肋の上昇，血糖の低下を認めた。

インスリン分泌は血管合併症を有する糖尿病で糖尿病全 例に比較して分泌反応は糖質負荷 ·脂肪負荷とも低下して いた.

ELT は糖質負荷・脂肪負荷とも短縮をみたが糖質負荷
に比較して脂肪負荷は短縮が軽度であった。

50. 老年者の血液粘度に関する研究（第 1 報）

都老人研 臨床第 2 生理

松田 保 児玉直子 秀野啓子 木村 緑 同 疫学

松崎俊久

都養育院付属病院

村上元孝

血液の面よりみた血栓発現の risk factor としては，血 小板, 線溶系をも含めた広義の血液凝固性の䒕進ととも に, 物理的な因子として, 血液粘度の元進を無視し得ない. 63 88 歳（平均 73.5 5.0 歳）の健常老年者（東京都老 人ホーム入居者で特に自覚症状がなく歩行可能のもの） 43 例につき，1/10 容の $0.1 \mathrm{M}$ 蓚酸ナトリウム液を加えて凝 固を阻止して採取した静脈血について，回転粘度計を用い て血液粘度を测定した，各検体につき， $37^{\circ} \mathrm{C}$ で，最高 4 . $6 \mathrm{sec}^{-1}$ より最低 $0.07 \mathrm{sec}^{-1}$ に至る 15 段階の異なった shear rateに拈ける血液粘度を測定し，これから作製した Casson plot に基づいて降伏值（yield stress）を求めた. その結果, ffn液粘度の平均は. shear rate $4.6 \mathrm{sec}^{-1}$ で 8 $\pm 2 \mathrm{cp}$ であり，以下 shear rate が低下するとともに上昇 し, shear rate $0.07 \mathrm{sec}^{-1}$ では $45 \pm 25 \mathrm{cp}$ であった。降 伏值の平均は $11 \pm 10 \times 10^{-3} \mathrm{dyne} / \mathrm{cm}^{2}$ である。ヘマトク リット值 $(\mathrm{Ht})$ の平均は $38 \pm 4 \%$ であったが，血液粘度 との間には有意の正相関が得られ（相関係数 $+0.61 〜+$ $0.82, \mathrm{P}<0.001)$, shear rate が高い場合の血液粘度との 相関がより高かった。降伏值も $\mathrm{Ht}$ と有意に正相関した （相関係数 $+0.35, \mathrm{P}<0.05)$ が，血液粘度との相関が高 <（相関係数 $+0.63 \sim+0.91, \mathrm{P}<0.001$ ), ことに shear rate の低い場合の血液粘度との相関が高かった。なお，加 秢によっても Ht には変動はみられなかったが, low shear rate に拉ける血液粘度ならびに降伏值は加齢とともに低下 する傾向がみられた。 21〜44 歳（平均 28.6士5.5 歳）の 健常若年者 84 例に拈いては, 各 shear rate に抢ける血 液粘度, 降伏值とも上記健常老年者例より高値を示したが, $\mathrm{Ht}$ が平均 $42 \pm 4 \%$ と老年者に比し有意に高いためと考え られる. Ht $39 \%$ 以上の健常老年者 20 例をとると, 健常 若年者の $\mathrm{Ht}$ とほぼ同一となるが，これらの例の血液粘 度，降伏値は，いずれも健常若年者例のそれより高くなっ ている（推計学的には有意差なし）。都立養育院病院入院 例中 shear rate $4.6 \mathrm{sec}^{-1}$ で血液粘度 $11 \mathrm{cp}$ 以上，また は shear rate $0.07 \mathrm{sec}^{-1}$ で血液粘度 $70 \mathrm{cp}$ 以上の例は 46 例みられたが，このうち 5 例は血管内凝固症候群 (DIC) に合併するかまたは後に DIC に進展したものであり，2 例は粘度測定後心筋硬塞に進展した。 また， 3 例は心筋硬 塞発作直後, 5 例は脳硬塞発作直後， 1 例は末梢動脈血栓 
発現後に測定したものである。核かに，脳硬塞または脳卒 中後遺症 10 例, 悪性腫瘍 9 例, 糖尿病 6 例, 多血症 4 例 などがここれらの血液粘度九進に含まれている。これらの 例に拈いても，Ht の高い例が多いが，DIC または悪性腫 瘍例では, Ht が比較的低いのに血液粘度の高い例もみら れる,

以上の成績は, 血液粘度の亢進が血栓症の発現に促進的 に作用すること, ならびに, Ht の上昇が血液粘度の立進 と密接に関連し, この点では生体に不利に作用することを 強く示唆するものと考劣る。

質問 : 角田興一〈大阪市住友病院内科〉

先生の data と小生の data で降伏值の order が約 10 倍異なっている。おそらく機械の精度のよるものと思われ るが，先生の使用されている粘度計を教えていただきた い.

\section{答：松田 保}

血液粘度の測定にはスイス製の共軸二重円筒型の回転粘 度計を用いている. $4.6 \sim 0.07 \mathrm{sec}^{-1}$ のズリ速度で粘度 測定が可能である．私の経験では， $1 \mathrm{sec}^{-1}$ 以上之 0.44 $\mathrm{sec}^{-1}$ 以下では，ズリ速度の平方根とズリ応力の平方根を プロットした直線のかたむさが違うように思う。先生の場 合と, 私の測定とではズリ速度に相違があるので, 降伏值 にも差が出たのかも知れない。

\section{1. 老年者の血管内凝固症候群に関する研究（第 1 報）}

都老人研 臨床第 2 生理

松田 保

同 臨床病理

大津正一

\section{都養育院付属病院}

村上元孝 白倉卓夫 金沢暁太郎 嶋田裕之

1972 年 7 月 1974 年 6 月に都立養育院病院において経 験した 60 歳以上の血管内凝固症候群（DIC）について報 告する.この期間の入院患者死亡例 464例中 72 例が DIC に進展した。 DIC 発現例の平均年歯（78.0土7.0 歳）と 非発現例のそれ（77.3士7.2 歳）との間に有意差は認めら れない. 悪性腫瘍 152 例中 43 例に DIC が発現したが, これに敗血症を合併した場合さらに DIC の発現率が高い (12 例中 9 例). 胃癌 51 例中 16 例, 肝癌 27 例中 2 例 食道癌 9 例中 1 例, 胆袈癌 9 例中 5 例, 膵癌 6 例中 3 例, 重複癌 5 例中 5 例に DIC の発現がみらら, 肺癌では DIC の発現率が低い。敗血症（㥶性腫瘍合併例を含さ） 34 例 中 18 例に DIC の併発がみられ, 悪性腫愓または敗血症 に拈ける DIC の発現率はその他の疾患に比し有意 $(\mathrm{P}<$ 0.001）に高い。このほか肺炎に合併した DIC が 7 例み られた。 DIC の診断は, 血管内凝固による消費に基づく と思われる血小板数, fibrinogen 量の低下のみられること
によるが,このほか prothrcmbin 時間の延長, FDP の増 加, eugloblin 溶解時間の異常, antithombin III, plasminogen, $\alpha_{2}$-macroglobulin の低下が高率にみられた. 出血 症状としては, 紫斑, 溢血斑, 皮下出血, 下血, 血尿, 口 腔内出血などが主なるのであるが，著しい凝血能低下を認 めながら著明な出血症状（消化器系悪性腫瘍における下血 を除く）を認めない例が 32 例みられた。このほか，無尿 ·乏尿 (45 例), 昏睡 (36 例), 急性腎不全 (33 例), シ ヨック (24 例), acrocyanosis (10 例), 心電図上心筋硬 塞様変化 (10 例), 全身痤攣 (6 例), 血栓性静脈災また は末梢動脈血栓症（6 例), 対称性壊疸（4 例）などが認 められた。すでに凝血学的に DIC の存在が咨われる時期 に出血症状がなく, その後出血症状をみた例は 19 例であ る.一般検査所見では, 赤血球 fragmentation 像, 網状 球増加, 血液 $\mathrm{pH}$ の低下, 赤沈值の遅延, 血清蛋白低下, 間接ビリルビン, LDH, BUN の増加もしばしばみられ, ことに赤沈值と BUN は, 悪性腫瘍例において DIC を合 併する例としない例との間に有意差 $(\mathrm{P}<0.001)$ がみられ た. 凝血学的に DIC と診断されてから死亡までの期間は 平均 9土10 日である。剖検 64 例中, 大血管 (22 例), 心 (15 例), 肺 (13 例), 腎 (13 例), 腸（7 例）などに 多少とも血栓の認められた例は 46 例であり, 心弁膜にお ける vegetation は 14 例（このらち悪性腫瘍が (12 例), 脳の多発性硬塞は 17 例にみられた. 消化管の浅い潰痬, びらん, 益血斑は 37 例にみられ, いわゆる terminal hemorrhagic necrotic enteropathy は 12 例に, 頭蓋内の大 出血は 3 例に認められた。

以上, 老年者に打ける DIC は決して珍らしいものでは ないこと,ただし, 症状, 経過などには症例によってかな り差のみられること, 早期診断は routine, かつ頻回に凝 血学的検查を行らことにより必ずしも不可能ではないが, 非定型的な症例も存在すること, 出血よりもむしろ血栓に 伴う臓器症状, ことに急性腎不全の発現を警戒すべきこと を強調したい。

質問：美原 恒〈神戸大第 1 生理〉

DICを示した症例のらち, 悪性腫癔, 敗血症の他に, そ の他という例があったが，それはどのような症例か。

またこれら原因疾患があり，DICを伴った症例の場 合，いかなる対応をさせるかご教示いただきたい.

答：松田 保

DICの治療には基礎疾患の治療が第 1 だと考えます。刘 症的にはへパリンを找与していますが，それによって凝血 能が改善しても, 㛑不全のため, 不幸な転機をとる場合が 少なくない。この点では, DIC を極めて早期に診断して 早期にへパリンを投与するか，またはウロキナーゼのよう な血栓溶解薬の投与が必要なのかも知れない.

墨性腫瘍, 敗血症以外の DIC の原因疾患としては, 肺 
炎, 劇症肝炎, 悪性高血圧症などに合併した microangi opathic hemolytic antmia, 心室瘤などがある.

質問 : 米田春毅〈大阪成人症センター〉

1）心内膜に血栓が形成された症例の内，何例心雑音を 聴取出来たか.

2）心血管系に血栓形成されたものは，心血管壁に異常 所見がない所にも血栓が形成されているか.

答：松田 保

Vegetation の存在と心雑音の有無については現在 デー タを持っていない，心弁膜の感染によると思われる变化に よる Vegetation は含まれていない. Vegetation が DIC の結果として生じたのか, また, Vegetation の存在その ものが DIC の発現に促進的に作用するのかは，今後の興 味ある問題だ思う。

\section{2. 動脈硬化と血液凝固機転}

聖マリアンナ医大 第 2 内科

渡辺勇四郎 針原京子 渡辺礼子 中込健郎

鈴木 博 大竹喬二 岡部和彦 須階二朗

従来より糖疗病患者に血管合併症ないしは動脈硬化性病 変が強く一方肝硬変ではそれら病変が少ないといわれてい る.そこでわれわれは対称的な両疾患を比較検討すること により動脈硬化の病態を把握しようと試みた。今回はとく に血液凝固系の面から両疾患を対比した，対象は血管合 併症を伴った糖尿病患者 41 名之肝硬変患者 20 名で各々 平均年齢は約 50 歳である。血液凝固外因子系の検査とし て Normotest を用い, 血小板機能は血小板凝集能をエバ ンズの血小板凝集メーターで, 血小板第 3 因子能をカオリ ン法により測定した。 線溶采は Lysin Cephalose による Affinity Chromatography により Plasminogen と Antiplasmin を分離測定し, 血漿フィブリノーゲンは Quick 法 により定量した，燐脂質分画は薄層クロマトグラフィーで 二次展開して定量した。

血液凝固外因子系検査の Normotest は糖尿病では 107\% と高く肝硬変の $60 \%$ と比し著明な差異がある. 血小板凝 集能は従来の算定方法では糖尿病で $61.4 \%$, 肝硬変で 45 . 1\%と両疾患に差異を認めるが，両者の血小板凝集曲線の Pattern に明らかな差異がみられるのでわれわれは ADP 添加より 1 分後の勾配 $\tan \theta$ を求めたところ糖疗病で 2 . 18, 肝硬変で 0.52 と著明な差異がみられ, 従来の方法よ り両疾患の病態の差異を著明に反影するようである。血小 板第 3 因子能は両疾患之も正常範囲内の変動とはい之糖尿 病 $56.8 \%$ 肝硬変 $41.5 \%$ と糖尿病に比し肝硬変で低値を 示した. 血小板凝集能および血小板第 3 因子能に対して燐 脂質の関与が強く想定されるので血清燐脂質及びその分画 をみると一番大きな変化は Lecithin で, 肝硬変で Lecithin が低值を示したが燐脂質分画だけから血小板凝集能及び血
小板第 3 匝子能に怙ける著明な差異を説明するわけではな い. 血漿フィブリノーゲンは肝硬変では糖尿病に比し明ら かな低值を示した。線溶系をみると Plasminogen は糖尿 病で $26.9 \mathrm{u} / \mathrm{m} l$ と正常と大差なく肝硬変では $23.5 \mathrm{u} / \mathrm{ml}$ と 稍低い。一方 Antiplasmin をみると正常 $64.3 \mathrm{u} / \mathrm{ml}$ に対 し肝硬変 $46,8 \mathrm{u} / \mathrm{ml}$, 糖尿病 $31.8 \mathrm{u} / \mathrm{ml}$ と糖尿病で明らか な低傎を示し, Antiplasmin, Plasminogen 比(Antipl/plg) をみると正常 2,51 に比し肝硬変 2.03 とわずかに低下し ているが糖尿病では 1.19 と半減しており糖尿病で線溶系 の克進が示唆される，そこでもら一度血小板凝集曲線の特 徵をみると糖尿病の曲線は勾配が急峻であるがその後の曲 線をみると大別して 2 つの Pattern に分汁られる。ひとつ の Pattern は著明な Disaggregation を起こす Pattern で この様な著明な Disaggregationを起こすものは線溶系 Antipl/plg. 比を見ると著明に低下して括り線溶系の立進 が示唆される. 他のひとつの Pattern は 2 相性を示し, こ の Antipl/plg 比は正常と汪とんど変わらず凝固系の充進 が示唆され興味ある所見である。

\section{3. 動脈硬化症に関する研究}

\section{脂質, 糖代謝と血液凝固能について}

金医大 老年病科

中村国雄 平井 洋 高畠 学 高折雅章 中田 勲 関本 博

動脈硬化症の成り立ち機序については，従来から多くの 央験や臨床像をもとに, 種々検討が加えられてきているが， いまだ見解の一致をみるまでにいたってはいない，今回我 々は動脈硬化症の臨床例を対象に脂質及び糖代謝異常と, 血液凝固能を比較検討し，動脈硬化成り立ちとの関係を明 らかにすることを目的として本研究を行なった。

対象は, 昭和 46 年以後剖検しえた 60 歳以上の老年者 117 例で, 脳硬塞による死亡は 65 例で脳出血は除外した. このらち糖代謝異常群は 12 例, 糖代謝異常を伴わなかっ た例は 53 例であった。肺炎その他の非脳死例で，剖検に より脳底動脈, 冠動脈, 大動脈などに動脈硬化のみとめら れた例は 52 例で, このらち糖代謝異常のみとめられた例 は 12 例, 糖代謝異常を伴わない例は 40 例であった。

結果：血清コレステロール值は，糖代謝異常を伴う動脈 硬化症群で加齢とともに増加する傾向がみられたが, 非糖 尿病群では著変はみられなかった。血清トリグリセライド 值は，糖代謝異常を伴う動脈硬化症群では 70 歳台に著明 に増加して拉り，糖代謝異常を伴わない群では 70 歳台で や〉減少していた，血清リン脂質值は，桾代謝異常を伴ら 群の 80 歳台ではやや減少していた。血小板凝集能は糖代 謝異常を伴う脳硬塞群で 70 歳台に著明に圥進していた. 糖代謝異常を伴わない群では，加秢による変動はみられな かった. プロスロンビン時間, 部分トロンボプラスチン時 
間には，大きな差をみとめることはできなかった。

\section{4. 老年の健常者, 虚血性心・脳疾患者の血液粘性 一青壮年者との比較一}

住友病限 内科

角田興一 宇佐美惕久 栗原 正

虚血性心・脳疾患の成立過程において，血液の物性ない しレオロジ一的な変化が関与している可能性がある。 Brookfield Microviscosimeter (LVT) にて. $37^{\circ} \mathrm{C}, 115 \sim 11.5$ $\sec ^{-1}$ のズリ速度で, EDTA-2K により抗凝固化した血液 のズリ応力を測定し，Casson の流動方程式を仮定し， 概 想法により降伏值 $\left(\tau_{\mathrm{f}}\right)$ を求めた.

健常例の $\tau_{\mathrm{f}}$ は, 若年群 $(20 \sim 39$ 歳：10 例) $: 0.133 \pm$ $0.034(\mathrm{~S} \cdot \mathrm{D} \cdot) \mathrm{dyne} / \mathrm{cm}^{2}[\mathrm{Ht}: 45.6 \pm 1.7 \%]$ (以下同単位); 壮年群 $\quad(40 \sim 59$ 歳：10 例 $): 0.164 \pm 0.034 \quad[45,1 \pm 3.5$

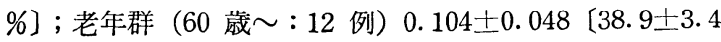
\%]で，Htを考慮せず倸価すると，若一-壮年群間 $(\mathrm{P}=$ 0.025), 壮一老年群間 $(\mathrm{P}=0.005)$ には有意差があった。 $\mathrm{Ht}$ を考慮すると，老年群の貧血傾向にもかわらず，壮・ 老年群の $\tau_{\mathrm{f}}$ は高いといえるかもしれない。

虚血性心疾患 $\left(47\right.$ 例) の $\tau_{f}$ を同年皊群の健常值と比較 するも，各群での Ht の差による影響と疾患例での $\tau_{f}$ の割 合に大きな散布のために，有意差は得られなかった。虚血 珄脳疾患（22 例）でも，健常値との有意差を見なかった。 また， $\mathrm{Ht}$ 効果以外の $\tau_{\mathrm{f}}$ に及ぼす影響をみるために, $\mathrm{Ht}$ を 42〜 48\% に限定した疾患群を各年秢群健常值と対比し ても，有意の差は得られなかった。 $\tau_{\mathrm{f}} \mathrm{Ht}$ と関係として， $\mathrm{Ht}$ 域 $30 \sim 60 \%$ では, $\tau_{\mathrm{f}}=0.104 \times \mathrm{Ht}-0.3158 \pm 0.0481$ (S.E.) $(\mathrm{r}=0.83)$ がえられた。この勾配に沿って疾患例の $\tau_{\mathrm{f}}$ を $\mathrm{Ht} 42 \%$ に移動し，それを修正降伏值（ $\left.\tau_{\mathrm{f} 42}\right)$ として 評価することを試みたが，若年一壮年一老年群の間にも， また，健常一疾患群の間にも有意の差を認めることがきな かった.

結論：全血の降伏值は, Ht 30 60\% では, Ht の一次 函数として決められるようであり，個々の疾患例での $\tau_{\mathrm{f}}$ の 評価にさいしては，この函数から大きくはずれた值をとる ものに血液レオロジー的な異常があると考光られる。

老年者での貧血傾向は評価をむづかしくするが， Ht を 考虑に入れると，壮年抢よび老年者の血液の $\tau_{\mathrm{f}}$ は若年者 のそれょり大きいかもしれない，虚血性心・脳疾患例での て は, 群としては健常例と有意の差がなかった。

\section{5. 網内系障害時における実験的高脂血症一動脈硬化家鬼 の颣固系線溶系の動態について}

東医大 老年病科

清水航一 渡辺佳俊 海老原隆郎 勝沼英宇

実験方法：体重 $2.5 \mathrm{~kg}$ 内外の白色雄性家鬼を用い, =
ンドロイチン硫酸鉄 $2 \mu \mathrm{ci} ， 4 \mathrm{mg}$ を耳静脈内に注入し，経 時的に採血し，血漿分離し，E.W. Boettchen の方法に従 ってコロイド鉄クリアランス解析を行なった。 RES 機能 の障害群には前処置群として央験前 3 日前より $10 \%$ 開明 墨汁 $5 \mathrm{ml} / \mathrm{kg}$ 注入し, 綱内系を充填した後, コンドロイチ ン硫酸鉄静注法を行なった。動脈硬化，高脂血症家鬼の作 成には $1 \%$ コレステロール含有飼料で飼育した家鬼を用 いた。

成績: 正常群の $\mathrm{Fe}^{59}$ Colloid clearance $\mathrm{T}^{1 / 2}$, すなわち 食食能は 5.5 分, Time Lag すなわち処理能は 1.4 日で あり, コレステロール飼育家鬼では $\mathrm{T}^{1 / 2}$ は 9 分で遅延し， Time Lagは 4.0 日と前者に比して網内系機能は低下し た．墨汁による前処置群で正常家鬼及びコレステロール群 の Colloid Clearance $T^{1 / 2}$ はそれぞれ 13 分, 14.5 分で 両群共遅延し, Time Lag \& 2.1 日 5.5 日と無処置群に 比し，RES 機能は貪喰能，処理能共に低下した。凝血検 查では無処置群はコレステロール飼育群にフィブリノーゲ ンの高値，Ca 再加試験の軽度延長を認めた。墨汁で前処 置したフィブリノーゲン量の変動は正常成熟家鬼は 1 時間 内に急激な上昇を示し，2時間後には下降し始めた。コレ ステロール飼育群ではフィブリノーゲンの上昇が軽度又は 不変を示した．FDP の測定は Staphylococcus cluming test を用いた，正常群は墨汁注射後 1 時間後に軽度上昇し 83. $2 \pm 38.4$ 倍数稀採であるに対し，コレステロール群では 1 時間後 $728 \pm 73$ 倍数稀勫之正常群に比し, 約 9 倍の增加 を認めた，第 VIII 因子では正常群では墨汁注入後 2 時間ま でに急激に減少後徐々飞恢復し，24 時間後でも 墨汁注入 前にもどらないに対し，コレステロール群では軽度の減少 を認めたにすぎなかった，第V因子では正常群では注入後 3 時間迄㴔激に下降後, 24 時間後も前值に復帰しない のに対し，コレステロール群では減少が軽度ないし，不変 を示した。

結語：実験的に若起した高脂血㱏, 動脈硬化家鬼では正 常成熟群に比し, 網内采機能は低下し, 且つフィブリノダ ンおよびリン脂質の増加により凝固圥進状態にあるが，実 験的に網内系機能が障害されると正常群に比し, FDP が 高度に上昇した点から，血中に Fibrin Monomer が高度 に存在していることが示唆され，この事は Fibrin Monomer が網内系機能の低下により処理されないことを意味し 網内系機能が血栓発生, 進展予後に密接な関連があるとい える。

56. 動脈硬化症の免疫組織学的研究（第 3 報）一特にフィ ブリノーゲンの動脈壁透過性について一

日大 第 2 内科

小林 功 八杉忠男 清水 隆 佐々英一原田衛 小針貞男 竹下治生 杉田勝一 今野久忠 


\section{$12: 106$}

\section{波多野道信}

動脈硬化の進展に，血管内容の浸潤が主役を演じている ことはよく知られているが,これを助長する因子として, 血 管壁の障害夾子も問題と考光られる。一方高コレステロー ル血症がそれ自身血管内容の浸潤を充進させるとも考えら れているそこで異種蛋白による㸡管障害とコレステロール 負荷による高コレステロール血症を家鬼に们成し，フィブ リノーダンを指標として䖝光抗体法により検討を加えた。

研究方法: 家鬼フィブリノーゲンをヤギに免疫し, 得ら れた抗体に䖝光色素 FITC をラベルした。実験には未処 置群, 異種蛋白免疫群, コレステロール負荷群, 異種蛋白 免疫にコレステロール食負荷群の 4 グループについて 1 週 間目から 6 週間目まで経時的に, 凍結切片法で家鬼胸部大 動脈より標本を作り染色，検索を加えた。

成績および考案: 未処置家鬼に捣いては血中コレステロ 一ル值は $59 \mathrm{mg} / \mathrm{d} l$ であり, 動脈内膜にフィブリノーゲン の螢光を認めるが極めて軽度で観察期間中特に変動はみら れなかった，一方異種蛋白免疫家鬼では血中コレステロー ル值は $56 \mathrm{mg} / \mathrm{d} l$ で期間中一定でありフィブリノーゲンの 浸入は 2 週間目まで增強し, 3 週間目で減少傾向を示し て, 6 週間目では未処置群と同程度となった。 コレステロー ル負荷のみの家鬼ではコレステロール値は 1 週間目で 312 $\mathrm{mg} / \mathrm{d} l$ と高值を示し， 6 週間目まで漸増し， $918 \mathrm{mg} / \mathrm{d} l$ に 達した。血管内膜のフィブリノーゲンの浸入は 1 週間目上 りかなりの螢光を示し， 2 週目， 3 週目と漸増しその後は 一定の染色度となった。異種蛋白免度とコレステロール負 荷を同時に行なった家鬼では血中コレステロール值は，コ レステロール負荷家鬼と同程度であったが，䖝光染色度 は， 1 週間目ですでに著明であり， 2 週間目で染色度は最 高に達し， 3 週間目以降は, コレステロール単独負荷群に 近ずく傾向にある。

結論：フィブリノーゲンの動脈壁への浸入は, 血管障害 やコレステロール負荷のような因子が加わると, 著明に增 加する点からこれらの因子は動脈硬化の発展に対する引金 となる可能性を示唆するものと考兄る。しかし，免疫学な 血管障害は, 単独では一過性のもので, 動脈硬化進展に影 響を与えるとは考光難い，しかし高コレステロール血症の 存在のもとでは重要な引金的因子となり得, 一方高コレス テロール血症はそれ自身 atherogenesity を発揮するものと 考兄らる。

57. 動脈硬化性疾患の Blood Fibrinolytic Activity に ついての研究 (第 6 報)

脳動脈硬化症に対する Heparinoid (DEXTRAN SULFATE) 長期投与例の検討

東医歯大 第 2 内科

三輪俊博 阿部恒男 小松文夫 松田美枝子
12 巻 2 号 $(1975: 3)$

目的：今回われわれは，脳血栓の既往のある脳動脈硬化 症のうち, Dextran Sulfate (DS) を 10 年以上投与し得 た 13 症例（平均年齢 71.7 歳）につき，凝固線溶動態を測 定したので報告する。また，脳血栓の発作をきたしたが， まだ治療を受けていない脳動脈硬化症例については，DS $30 \mathrm{mg} / \mathrm{kg}$ を 2 力月経口投与し SFMC の変動を調べた。さ らに, 各種内科疾患の血漿 Fibrinogen 量之血漿 SFMC, DTT と STT-O' の相関についても検討した.

方法: 検查項目は Fibrinogen, EngLT, EngLA, STT $-\mathrm{O}^{\prime}$, DTT, 血漿扣よび血清 SFMC (Lipinski 法), $\beta$ リ ポタンパク中性脂肪, 総コレステロールなどである.

成績：DSを 10 年以上投与し得た例において，DS 投 与前には高 Fibrinogen 血症, Plaminogen activator 活 性の低下, STT-O' の短縮, $\beta$ リポタンパク・中性脂肪・ 総コレステロールの高值傾向などがみられたが，これらは DS 投与後経年的に改善され，かり臨床的に脳血栓の再発 は認められなかった。脳動脈硬化症 7 症例では，血漿おょ び血清 SFMCは DS 投与前高值を示したが，投与 2 力月 後，いずれも正常化した．血清/血漿 SFMC 比は，投与後 改善をみたが，コントロールに比し依然高值であった。血 漿 Fibrinngen と血墏 SFMC, DTT と STT-O'（22 秒以 内）は高い正相関を示した.

考察掞よび結論：高 Fibrinogen 血状態は血中 Fibrinogen-Fibrin monomer Complex が増加して拉り, 凝固能立 進傾向を示唆していた，DS 投与によっても血清/血墏 SF MC 比がな拉高值を示すことは，FDP-Fibrin monomer complex の高值を意味する．生体内の凝固充進に対し線溶 処理がなされているのである. DS は，血清 SFMC，血漿 SFMC，STT-O' おょび血中脂質を改善させるので，血栓 形成の抑制に好ましい結果をもたらすものと思われる.

質問 : 岡部和彦〈聖マリアンナ医大第 2 内科〉

(1) Dextran sulfate を投与しない他の治療による con. trol の成績をお持ちか？

(2) 臨床的に有効の投与量はどの位か？

(3) 本剂の性質上長期投与の場合には他臓器への影響が 考られると思らが如何か？

答：阿部恒男

従来の高齢者の脳血栓症の治療のみでは予後は再発作を おこしていわゆる脳軟化症になってしまう症例が少なくな く，それを予防できないかといらことで 10 年間継続投与 しえた 13 症例を扮示した，投与量は線溶正常化を目的と すると $30 \mathrm{mg} / \mathrm{kg}$ がよいと思う。

\section{8. 動脈硬化症における血漿フィブリノーゲンの意義につ いて (VII)}

兵庫㝠立淡路病院 内科

松永公雄 松尾武文 八尾宣明 吉田 睦 石浜義民 


\section{神戸大 第 1 内科}

友松達弥 福崎 恒

今回は,フィブリノーゲンとオイグロブリン溶解時間 (ELT と略) について, 心笳硬塞, 脳血管障害の脳出血, 脳血栓の経時的变化を報告する.

対象：新鮮心筋硬塞 18 名, 脳出血 26 名, 脳血栓 29 名, 正常者 34 名の計 107 名である.

方法: オイグロプリン溶解時間, 血墏フィブリノーゲ ン, オイグロプリン 2 分屑中のフィブリノーゲン, コレス テロール, 中性脂肪, 遊離脂肪酸を测定した. オイグロブ リン 2 分属中のフィブリノーゲン対 $\mathrm{ELT}$ の比 (FI) を計 算した。各々測定值の発作後の第 1 病日から第 5 病日の 群, 第 6 病日から第 20 病日の群, 第 21 病日より第 50 病 日の測定群の 3 群に分け検討した.

結果

\section{A. 脳出血と脳血栓}

1）血漿フィブリノーゲンではいずれの病日でも正常者 の $260 \mathrm{mg} / \mathrm{d} l$ より高い值を示したが, 脳出血, 脳血栓の間 に有意の差はなかった。

2) ELT, は脳出血, 脳血栓とも $6 \sim 20$ 病日で延長す る同一のパターンを示した. 正常者と比較すると脳出血で は差はなく脳血栓では短縮傾向があった. 21〜50病日では 両者に有意の差がみとめられた.

3） FI，を計算すると脳出血では正常者と有意の差はな いが脳血栓では FI の值は高く線溶活性が促進傾向にある と考えた。

\section{B. 心筋硬塞}

1）血墏フィブリノーゲンは生存例では $1 \sim 5$ 病日に最 も高く次第に減少するが，正常者に比し全期間中有意に高 かった. 死亡例では $6 〜 20$ 病日以降に生存例に比し低い值 をとるもの多かった。

2）ELT は生存例では $1 \sim 5$ 病日に著明な延長を示し, $6 \sim 20$ 病日以降では短縮を示した. 死亡例では $6 〜 20$ 病日 以降に生存者に比し延長するものが多かった。

3） FI. を計算すると生存例では正常者に比し $1 \sim 5$ 病 日で低值を，6〜20病日以降では高值をとった. 死亡例で は $6 〜 20$ 病日以降生存例に比し低值をとった.

4）生存者心筋硬塞発作後の遊離脂肪酸, コレステロー ル，中性脂肪は各群に有意の差が認られなかった。

結論 : 脳卒中と心筋硬塞発作後の線溶活性の変化を経時 的にみた。 その結果, 脳血栓は脳出血に比較して線溶活性 の促進傾向がみとめられた. 心能硬塞では, 発作後に線溶 活性は遅延し病日を経るに従って促進する一定の傾向をみ とめた。

\section{9. 糖尿病に伴う動脈硬化合併症と線溶凝固機序との関連 について}

国立京都病院糖尿病センター 内科

赤澤好温 小出操子 山島英世 東 淑江 永田弘治 出井勝重 服部 譲 高安正夫

糖尿病における血管障害促進因子の解明を目的として, 本院糖尿病センターにて治療管理中の 45 例の糖尿病患者 について年齢, 䍜病年数, 高血糖, 脂質（コレステロー ル, 中性脂肪), 血漿中フィブリノーゲン, 線溶を代表し てューグロブリンライシスタイム, GTT 時の IRI 值の総 和 $(\Sigma \mathrm{IRI}), \quad \Sigma \mathrm{IRI} / \Sigma \mathrm{BS}, 30$ 分值の $\Delta \mathrm{IRI} / \Delta \mathrm{BS}$, 血圧, 網 膜症, 心電困の変化, 蛋白尿 (腎症), 他の血管障害, 出 血, 凝固時間, プロトロンビン時間，血管脆弱性，血小板 数, 低血糖発作, 肥満度 (体型), ノイロパチー, GTT 時 の $\mathrm{HGH}$ 值の和，等についての関連を検討した。

症例 45 例中, 血管障害の合併例は 26 例であった。 方 法として, 血中フィブリノーゲンは本院出井, 菱本らによ る微量比濁法, ニーグロブリンライシスタイムは英国カー ナマン社製にチャンネルオートマチックタイムレコーダー により測定した.

測定成績：血中フィブリノーゲンが加齢と共に増量し， 糖尿病にて上昇傾向があり，血管障害例にしばしば著明な 増量を伴うことは, 既に本学会および日本糖尿病において 報告して来たが，本研究においてもフィブリノーダン 400 $\mathrm{mg} / \mathrm{d} l$ 以上に血管障害症例が多く $500 \mathrm{mg} / \mathrm{d} l$ 以上にては ほとんどの例に著明な血管合併症をみとめ，これは特に年 齢との関連は認められなかった，病歴との関連については 病歴 3 年以上に高值例を多く認めた。 血中コレステロール との関連については, コレステロール $250 \mathrm{mg} / \mathrm{d} l$ 以上でフ イブリノーゲン $500 \mathrm{mg} / \mathrm{d} l$ 以上は全例血管障害を伴った. すなわちこの両者は血管合併症のリスクファクターである ことを示す．高血圧との関連についても血圧 150 以上フィ ブリノーゲン $400 \mathrm{mg} / \mathrm{dl}$ 以上に血管障害例を多く伴ってい た.すなわち高血圧は高フィブリノーゲン血症と共に血管 障害の発症機序と何らかの関連を有する。線溶能を示す ELT との関連について調べてみると, 高フィブリノーゲ ン $(400 \mathrm{mg} / \mathrm{dl}$ 以上) が各時間帯に拡がり必ずしも平行せ ず, むしろ高フィブリノーゲン血症の際 ELT の短縮も みられ，生体の凝固線溶系の複雑な調整を示している.む しろ血管障害は高フィブリノーダンまたは線溶能の低下の いずれか一方が著明であれば血管障害を促進するとの印象 を受けると共に凝血と出血との複雑にからみ合ら糖尿病網 膜症の病態の一端も高フィブリノーゲンと線溶能の亢進に より説明出来る症例もあった。このような症例として 64 歳の男で網膜の出血の前にフィブリノーゲン $500 \mathrm{mg} / \mathrm{d} l$ に 増加と ELT との亢進を見た。このような血管障害と各 種 Date との関連を示す四表を作整し，年龄，病歴，血 糖, コレステロール, 中性脂肪, フィブリノーゲン, ELT, $\Sigma \mathrm{IRI}, \quad \Sigma \mathrm{IRI} / \Sigma \mathrm{BS}, 30^{\prime} \Delta \mathrm{IRI} / \Delta \mathrm{BS}, \mathrm{GH}, \mathrm{BW}$ Index, 血厈 
$12: 108$

の相関を示すと，糖尿病の血管障害の発症進展は病歷，高 血糖, 高脂血症, 凝固穴進, 線溶低下, Insulin 不足, 高 血圧等の総和として表われるものと推定し, 総合的治療の 必要性を強調した.

\section{Screen Filtration Pressure 法による血小板凝集能 測定に関する基礎的研究}

名大 第 3 内科

葛谷文男 吉峯 德 小林倫子 森 邦雄

従来行なわれて来た血小板凝集能検査法は主として吸光 度法であった。この方法は血小板浮遊血墏を得るために遠 心その他の操作を行なら必要があり血小板損傷の危険性が ある。

Screen Filtration Pressure 法 (以下 SFP 法と略す) は 全血を用い採血後直ちに所要の㠜集催起物質を混入し血小 板凝集能を測定出来るといら利点がある。 今回は in vitro に拈ける ADP およびノルアドレナリンによる血小板凝集 能を Evans の Aggregometer と本法 (SFP 法) の両者 について同一血液を用いて測定し比較検討した。すなわ Evans の Aggregometer による再靦性と本法との再現性を 比較した．SFP 法は極めてよい再現性を示した。従来吸 光度法による血小板凝集能の測定は日差変動, 径月変動が かなり顕著で，個々の症例によるばらつきも大きく，血小 板凝集能の比較ないしは経過観察に対する結果判定は極め て慎重を要するといわれて来た．SFP 法はこの点变動が 少なくすぐれた方法といえる。一方 SFP 法に用いられる ストレンゲージの信頼性その他の基礎的検討も行った，す なわち水銀圧力計による圧負荷と压記録装置との関係を調 查したが極めて鋭敏な反応と正確度を示した。ささらに in vitroに打けるADP 凝集に対して ADPの Dosis Response が SFP 法によって認め得るかを検討したところ加えられ た ADP の量と SFP 法によって示される圧力との間に直 線関係が得られた。しかしノルアドレナリン凝集に対する Dosis Response は認められなかった。 その理由に関しては 現在検討中である. しかし少なくとも次の事はいい得る. すなわち ADP による凝集とノルアドレナリンによる凝集 のメカニズムまたは凝集状態が異なっているといら事であ る。ともあれ SEP 法は ADP 凝集に対して再現性がすぐ れ血小板凝集能検查法としてすぐれた特微を持っている. しかしノタフドレナリン凝集に対する判定は慎重であらね ばならないと考へる。

\section{1. 老年者における急性心筋硬塞症}

東京逓信病院 循環器科

渡辺 潔 関口 寿 花岡和一郎

帝京大第 1 内科

佐藤友英 宮下英夫
12巻 2 号 $(1975: 3)$

河北病院内科

上妻和矩 国府田静生 條浦旭 深谷 弘 小笠原道夫

厚生年金病院内科

浅野 浩 横内 章 島田悦男 山根至二

井上病院内科

石川和夫 板倉純夫

中島病院内科

渡辺滋堯 畠山正己

東京都内および近郊 5 力所の病院で昭和 47 年 10 月より 18 カ月にわたる期間の間に急性心筋硬塞発病後 72 時間以 内に各施設の C. C. U. に収容された患者について死因の 重要な risk factor である加柃を中心に調査，考察を試み た. 症例は 58 例で年龄は 42 歳から 88 歳にわたり, 男 子 46 名女子 12 名であった。 心筫硬塞の診断は心電図, 血清酵素値より診定し, 硬塞発症より 4 週間に死亡したも ののみを急性期死亡例として集計した。患者群は 65 歳以 下と 66 歳以上に分けて致命率を比較した所 65 歳以下は $18.8 \%, 66$ 歳以上は $34.6 \%$ で高齢者に高い傾向を示し た．さらに高㱓者の心筋硬塞の特徽として以下のことがみ とめられた。 (1) 66 歳以上の患者群では男性の致命率 22 . $2 \%$ ，女性 $62.5 \%$ と女性の致命率が高い，(2) 66 歳以上 の下壁硬塞の致命率は 44.4\%, 広範囲硬塞 $100 \%$ で 65 歳以下と比して高值を示す。 (3) 66 歳以上で心源性ショッ クを合併したものの致命率は $80.0 \%$ で 65 歳以下と比し て高值を示す. (4) 66 歳以上で不整脈を合併したものの致 命率は $44.4 \%$ で 65 歳以下の $5.5 \%$ とでは危険率 0.01 で統計学的に有意差が認められた。(5) ウッ血性心不全の 66 歳以上での発生頻度 $46.2 \%$ は 65 歳以下の $12.5 \%$ 之 比して危険率 0.01 で有意に高值を示した。その他年龄に 関係なく男女の致命率を比較してみると男性 $17.4 \%$, 女性 58. $3 \%$ で危険率 0.05 未満で女性が有意に高値を示した. また 65 歳以下で，C.C. U. に 6 時間以内に収容された患 者群の致命率は $11.1 \%$ で Natural course の致命率 30〜 $40 \%$ に比してはるかに低く 65 歳以下の心笳硬塞発症後早 期の C. C. U. への収容の重要性を示した. な打全症例の致命率は $25.9 \%$ であった。

62. 心筋硬塞症の臨床統計（第 2 報） 一急性期の理学的所見を中心として一

名大 第 1 内科

谷村英彦 横田充弘 渡辺佳彦 安井昭二

名大 中検

外畑 㦑

名保衛大 内科

水野 康

愛知県総合保健センター 
岡本 登 岩塚 徹

名古屋掖済会病院

東 貞光 坂 行雄

名古屋第一赤十字病院

堀一彦 堀場希次

中京病院

大石 洋

心筋硬塞発作後 2 力月以内に名大病院拈よび 15 の市中 病院に入院した心筋硬塞患者 515 人を対象として，その理 学的所見と予後との関係を検討した。刘象 515 人の内訳は 男 427 人（死亡 101 人），女 88 人（死亡 26 人）で，男 女の死亡率はそれぞれ $23.7 \%$ と 30.2\% で，女の死亡率 の方が高かった，再発例は 45 例（死亡 22 例）で死亡率 は 48.9\% と高かった。対象の年齢分布をみると， 60 歳 代が最も多く, ついで 50 歳代, 40 歳代, 70 歳代, 30 歳 代, 80 歳代の順で, 20 歳代でも 3 例みられた。 死亡率は 50 歳代までは比較的低く, 60 歳以上は加齢と共に高くな る傾向を示した。心電図診断による心筋硬塞の部位は前 壁，下壁，前側壁，前下壁の㟲に多かった。死亡率は硬塞 部位の範用が広がる程高くなった。初診時ショックは約 $1 / 3$ の症例にみられた. ショックの程度を軽, 中, 重症に わけると, ショックの程度が強くなるほど死亡率は高くな り, 重症例では $80 \%$ をこえた。不全は約 $1 / 3$ の症例に みられた。その程度を軽, 中, 重症にわけると, 重症にな るほど死亡率が高く，重症例の死亡率は $85.5 \%$ であった。 初診時チアノーゼ約 4 人に 1 人の割合でみられ, 死亡率は チアノゼ想が $16.3 \%$ に対し，チアノーゼ有は $46.0 \%$ と 高かった。初診時の脈拍数と予後についてみると，毎分 100 以上の頻脈の例は約 5 人に 1 人の割合でみられ, 死亡 率も $50.7 \%$ と高かった. 初診時の最高血圧と予後につい てみると, 最高血圧 100 以下が $18.5 \%$ にみられ, 死亡 率も 38. 7\% と高かった。 硬塞発作後 1 週間以内の最高体 温と予後についてみると， $37.0^{\circ} \mathrm{C}$ 以上の発熱例が $85.6 \%$ あり，死亡率は体温が上昇するほど高くなる傾向を示し た.

質問 : 前田如矢〈阪市大第 1 内科〉

1）心雑音の性状よりみて, 硬塞後 VSD, 乳頭筋不全 などが考えられる例はどのくらいみとめられたか.

2）死亡までの日数と年龊との間に関係はみられなかっ たか.

\section{答 : 谷村英彦}

心箭硬塞の合併症である心室中隔欠損は 515 例中 4 例み られた。杂倠音は総数 490 例中 63 例に聴取された. 死亡 までの日数と年齢の関係は分析していない.

\section{3. 心筋硬塞の病理学的および組織計測的研究への試み} （第 2 報）

\section{Pathological and Histometrical Study of Myo. cardial Infarction}

東大 第 4 内科

村田瑞穂 伊藤良雄

都老人総合研究所

大津正一

心臓血管研究所

傅 隆泰 渡辺 担 新谷富士雄 小山晋太郎

心筋硬塞巣の定量化への試みとして, 組織計測的方法に より心笳病巣を量的に表現し，臨床像と対比検討した結果 を前回の本学会で報告した．今回は症例を追加して心筋硬 塞の死因に関する病理学的背景, 特に心笳壊死巣と胼胆巣 の量的差異について検討した.

対象と方法：症例は初回もしくは再発作の急性心筋硬塞 でショック，心不全あるいは不整脈で死亡した 27 例で, 前回報告した 22 例のなかから 17 例とさらに 10 例を追 加したもので，男 23 例，女 4 例，年秢は 49 歳から 82 歳まで平均年齢は 65.7 歳である. 臨床所見から死因を 4 群に分けた。すなわち 1 ；心原性ショック。I I A 左心不 全で 48 時間以内に死亡. II B; 左心不全で 48 時間以上 生存し， 3 週間以内に死亡. III ; 不整脈.

病理学的にはまず冠状動脈を連続横断し, 割面の性状か ら硬化の程度，血栓抢よび壁内出血の有無を検索した．左 前下行枝及び左廻検枝を 3 つの区域，右冠状動脈を 4 つの 区域に分けて，それぞれの区域の内腔狭窄度を百分比であ らわした．次に心をその長軸に対し直角に 3 等分し, 上, 中, 下位の横断切片のアザン染色標本をつくり, Point counting 法によって組織学的にそれぞれの心竻壊死巣および胼胆巣 を計測し，百分比であらわした．3つの高さの病巣比を平 均して平均病巣比とした。

結果：27 例のうち初回硬塞例は後壁中隔硬塞の 1 例の みで，他の 26 例はいずれも再発硬塞である。すなわち新 鮮および陳旧硬塞の重畳したものでは, 全周型 8 , 前壁広 範型 5 , 後壁広範型 3 , 全周型十前壁ないし後壁広範型 4 例であり，新鮮扣よび陳旧硬塞が異なる部位にあるものは 6 例で，いずれも前壁と後壁に別估にみられた，死因と硬 塞部位との間には一定の関係はないが，心内膜下硬塞例に はショック例はなく大半が心不全を呈していた。

冠硬化はいずれも高度であり冠狭窄の程度之死因々の間 に一定の関係はなく，冠血栓の有無と死因との間にも決ま った関連はない。

心筋壊死巣比沶よび胼胆巣比の平均病巣比を 27 例につ いて平均寸ると, 心笳壊死巣比 $10.7 \%$, 胼胆巣比 $15.8 \%$, 総病巣比 $26.5 \%$ である。これを群別にみると, I 群の 4 例では心筋壊死巣比 $17.3 \%$, 胼胆鉴比 $7.5 \%$, 総病巣比 $24.9 \%$ である. I 群の総病巣比は他の群と比較して最も 小さいが，心筋壊死巣比は逆に最も大きくいずれも総病巣 
$12: 110$

比の $50 \%$ を越えて扣り, ショックと心秎壊死量とは密接 な関連のあることが示唆された．II A 群汸 5 例で心等壊死 宩比 $11.5 \%$, 胼胆巣比 $15.2 \%$ である。 II B 群は 9 例で 心筋壊死巣比 $10.6 \%$, 胼胆巣比 $17.7 \%$ で II A と II B は 類似の病巣比を示して抢り, I 群と比較して胼胆鉴比が大 さい，林群は 9 例で心筋壊死巣比 $7.5 \%$, 胼胆巣比 $17.9 \%$ で心筋壊死巣比は他の 3 群と比較して最も小さい傾向にあ る。しかし, 胼胆巣比は症例によってかなりまちまちであ る.

質問 : 岡田了三〈順大循環器内科〉

上中下 3 切片でみられた硬塞の大きさの評価と, もっと こまかく serien でみた場合と一致するものか？

答 : 村田瑞穂

広範囲硬塞の 3 例について, 左心室の連続横断標本をつ くり, 心筋壊死巣および肝胆巣の左心室壁に対する容積比 を求めたものでは, 上, 中, 下位の 3 つの高さの平均病巣 比の結果と非常に近似值を示していた. 今後, 例数を増や して。検討したいと思う。

\section{4. 心筋硬塞における冠細小動脈の病変とその意義}

日医大 第 1 病理

小野正博 香中洋一 五味㴊誠 矢島権八

同 : 第 1 内科

大楠善彦

心筋硬塞に関連して冠血栓症の発生機序について, その 発生原因を我々は冠末梢循環不全に求めている.

これまでに剖検心心筋硬塞 38 例にて, 冠動脈を光顕的 には, 冠基幹枝基始部より末梢に至るまで采統的に冠動脈 障害形式の分類に基づいて，各オーダーの血管の内膜扣よ び中膜の障害度を検討し，ことに電顕的には急性期心筋 硬塞 7 例にて冠細小動脈を中心に詳細に検索し報告してき た.

これによると, 冠基幹枝基始部の内膜の機械的破壊と血 液成分の浸淫所見および冠細小動脈を中心とした内膜中膜 の高度な壁障害を明らかにした。一方電䫒的検索では, 内皮 細胞は萎縮しその細胞間隙の開大，PAM 陽性基底膜の断 裂消失とし, この領域の血漿成分の浸淫所見, 中膜笳細胞 の著しい浮腫空胞化ならびに基底膜様物質の增加, Collagen の形成が認められた。

我々はさらにこの所見を追求する目的で，動物を用いて 実験的心笳障害を作成し詳細汇検索した。

成熟家鬼 10 匹を用い，それぞれアドレナリン $10 \mathrm{mg} / 1 \mathrm{~g}$ Difco 製エンドトキシン $50 \mathrm{mg} / 1 \mathrm{~g}$ とその併用群に各々 3 匹 つう三群に分け,一匹をControl とし, その結果併用群とア ドレナリン群の 2 匹に心筋硬塞が起こり, 心電眓掞よび剖 検にてこれを確認し非硬变群では, 線維性肥厚による血管 内腔狭小化が特徵的だった。一方電顕的には実験的硬塞群
12 巻 2 号 $(1975: 3)$

と剖検心心笳硬塞は, 類似した中膜筋細胞の浮腫空胞化を 主体とする障害像を得, 非硬塞群では内皮下扰よび中膜筋 細胞基質に PAM 陽性の filamentous structure をもつ線 維成分の増加，ならびに細胞質間隙内にも，Collagen 様物 質を認め,この間隙が基質に開口している所見を得た。 ルジ体がよく発達しその周辺に基質の電子密度と類似した Vesicle の増加扣よびこの Vesicle の基質への開口融合所 見を認めた。

結論

1. 中膜笳細胞は浮腫空胞化の後に, 中膜線維化を残す ことが，極めて多くCollagen 生成に主役を演じ内皮もこ れに関与している所見を得た。

2. 些験的および剖検心心筋硬塞で，冠末梢領域にて中 膜筋細胞の histolytic lesion を主体とした血管病態を認 め, これらの冠逸脱性障害像を直ちに心筋硬塞発生の原因 に求める訳にはいかないが，あくまでも SHEEHAN DA. VIS らの実験結果を支持する所見であり，Autoregulation としての冠細小小動脈の破綻の結果, 著しい末梢循環の乱 れを生じその結果, 内圧六進の総和として冠血栓が二次的 に発生し，一方心筋不可逆性变化を生ずるものと考兄る.

質問：野原義次〈京大第 3 内科〉

Infarction 時の冠末梢循環動態は筋層全体に立って同じ であったか，差があったか.

答 : 小野正博

心笵硬塞における冠動脈壁障害は，硬塞部位によって冠 動脈壁の壁の相違性は認められず。

急性期心筋硬塞においては, 末梢領域の中膜筋細胞の浮 腫空胞化が著しい所見が主であった.

\section{5. 心笳硬塞と冠状動脈硬化・血栓の関係}

\section{一特に性差・加齡の影響について一}

順大 循環器内科

岡田了三 加納達二 北村和夫

目的：日本人心筋硬塞の成因として, 冠状動脈硬化およ び血栓形成に特徽的所見が発見できるか？特に加齢と男 女差を中心に形態学的に検討した。

対象：亜連続剖検例上り心筋硬塞 215 例（実硬塞数244） を選び，冠状動脈をWHO 方式に従い多数横断面観察に より精査して狭窄度・アテローム硬化の広がりを肉眼的に 判定した. 血栓の存在は主として肉眼的に診断したが，陳 旧性血栓の判定は一部顕微鏡的に行なった。男 129, 女 86 例よりなり，年踰は 23 歳より 91 歳まで，平均男 68.2 歳, 女 74.3 歳であった。年齢区分は若年 (20 39 歳), 壮年 $(40 \sim 59$ 歳), 老年 $(60 \sim 69$ 歳), 高老年 $(70 \sim 79$ 歳), 最老年 (80 歳以上) とした。

成績 : (1) 冠状動脈血栓の出現率は心筋硬塞の型により 相違し大量壊死 $(M)$ 型で男 $70 \%$, 女 $63 \%$, 広沉心内膜下 
(Sub) 型で男 $11 \%$, 女 $40 \%$, 散在壊死（S）型で男 $11 \%$, 女 $29 \%$ であった（2）年龄差では男性老年で $65 \%$ ，女 性高老年で $61 \%$ と最高血栓出現率を示すが，とくに KM 型硬塞では同年龄区分で男 $84 \%$ ，女 $69 \%$ となる。硬塞 の大きさで血栓出現率をわけると径 $5 \mathrm{~cm}$ 以上の大型 $M$ 型硬塞では男性壮年で $89 \%$ ，女性高老年で $80 \%$ となる. (3) 冠状血栓の部位は, 前下行枝に男 52 , 女 24 : 右枝に 男 34, 女 23 : 回旋技に男 17 , 女 9 となり, 男性では各 年代とも前下行枝優位, 女性では最老年で右枝優位とな る. 硬塞部位は男で前壁 (A) 76, 後壁 (P) 52, 側壁 (L) 29, Sub 16. 女で A 44, P 47, L 25, Sub 5 となり, 男性に前下行枝血栓 - 前壁硬塞優位, 女性に 3 枝平均化 た血栓・後壁硬塞優位がみられた，(4）冠状動脈狭窄度を 血栓を除く 3 主要技最高狭窄度を加えて 3 で除し予想内腔 の\%狭窄として表現すると, 男女ともSubで 73\%，M で 60〜68\%, Sで 43〜 63\% となり, 後壁硬塞とくに S 型を 除くと 50 歳以後で年㱓にかかわらずほぼ一定の狭窄であ った.（5）冠状動脈総内膜面積に対するアテローム硬化面 積の \% で硬化の広がりを示すと, 男女とも加齢とともに 硬化は広がり, 壮年 $40 \%$, 老年 $50 \%$, 高老年 $60 \%$, 最 老年 $70 \%$ と加秢と相関して進行する.

結論と考案 : 硬塞心にみられる冠状硬化は広がりとして は加齢とともに大となるが, 主要枝の最高狭窄度は 50 歳 以後で一定で, 硬塞は冠状動脈狭窄が限度に達すると発生 することを示す，狭窄を強めない硬化は加龄により進行し ても，硬塞とは一義的な相関はない。

冠状血栓は本質的にはM型硬塞と対応し, その好発年龄 に明らかな男女差を示す，基盤となる冠状狭窄度に明確な 性差を認めないため, 壮・老年期の男性には狭窄以外の血 栓好発因子が動くのか，女性に保護機転があるのかどちら かであろら．男性に前下行枝血栓・前壁硬塞が多いことも 注目に価する。

犋問 : 小沢利男〈東大老人科〉

1）血栓のある部位における冠状動脈硬化は如何.

2) 発症後から死亡までの時刻, 冠状動脈検索の方法に よって血栓の頻度に差が生ずると思われるが如何.

答 : 岡田了三

血栓の出来る場所は, 加㱓とともに狭窄のもっともつよ

い部位にできる傾向がある.

血栓が全部 2 次的に出来るとは思えない.

$30 \%$ 程度は 24 時間以内に死亡した例でも血栓かみられ るので, ある程度は原発性にみられるものもあると思う。

タテ切りとヨコ切りではたしかに血栓発見率がことな る. 横断面でみたあとにタテ切りにして確認するのが正し い方法と思う。
日医大 第 1 内科

金澤正邦 浜本 紜 毛利龍彦 小川 剛 馬㴊原一 早川弘一 栗田 明

対象：定型的な狭心症発作を有するも，安静時心電図に 異常所見を認めず，2 階段運動試験 (double) あるいは treadmill 試験にて虚血性 ST 降下を示した学作性狭心症 8 例 (男 6 例, 女 2 例, 年㱓 37 歳から 69 歳).

方法：仰臥位用自転車エルゴメータを用いる運動負荷に より虚血性 ST 降下ないし狭心痛を来たす負荷量をあら かじめ定めて扣き，このテストの 2〜3 日後に左心カテー テル法を行ない, YHP 8890 A あるいは日本光電製 MR 2 型レコーダに接続した Stetham P23Db トランスジ ューサーにて, 左室内压, $\max \mathrm{dp} / \mathrm{dt}$ を計測, 一方右房よ り Indocyanine Green を注入し, Hamilton 式を用い色素 希釈法より心拍出量を計算.ささにこれらの值から左室仕 事量, TTI, 及び $\mathrm{V} \max$ を求めた。 $\mathrm{V} \max$ の算出には Mason法のほか一部の症例では我々の作成した $\mathrm{V} \max =$ $\max \mathrm{dp} / \mathrm{dt} / \mathrm{IP} \times 0.114-0.98$ なる回帰式を用いた。なお V max は心筋収縮性の指標としては適当でないとされるが， 心筋酸素消費量を示すindexの1つとして用いた，安静時 の各種計測值を得たのち, 前述の運動量を負荷し, それら の值を再び計測した，次に，運動による影響が消失するの をまち, Propranolol 2〜4mg を5 分前後かけて静注，そ の 5 ないし 10 分後に前述の運動量を負荷, 運動前後の各 值を計測した。

成績 : 運動負荷により心拍数 **, 左室抁張末期圧 **, $\mathrm{TTI}^{* *}$, 橈骨動脈平均圧 *, 左室収縮期圧* は有意の上昇 を示したが $(* \mathrm{P}<0.05, * * \mathrm{P}<0.01)$, 心係数, 左室仕事量 $\max \mathrm{dp} / \mathrm{dt} \mathrm{V} \max$ は上昇傾向はあるも, 有意ではなかっ た. Propranolol 投与後, 安静時の各計測值は投与前之有 意の差を示さなかったが，運動負荷による心拍数，左室収 縮期圧， $\max \mathrm{dp} / \mathrm{dt}, \mathrm{TTI}, \mathrm{V} \max$ の上昇は投与前にお ける上昇に比し有意の差をもって抑制されるのがみられた (いずれも $\mathrm{P}<0.05)$.

結論 : Propranolol の抗狭心症効果のメカニズムは一般 には心筋酸素消費量の減少によるとされるが，以上の我々 の成績より，特に運動による心筋酸素消費量の増加を抑制 することにあると結論される。

質問 : 外畑 巌〈名大中検〉

プロプラノロール処置前後の data の処理方法はどの上 りにされたか？このよらな data には paired t test を用 いれば有意差の検出力が大きいと思うがいかがか？

答 : 木村栄一

ご指摘のごとく，たしかに処理がまちがっていたように 思われる。

\section{7. 虚血性心疾患における尿酸値の検討}




\section{昭和大 第 3 内科}

五十嵐 寞 塩原保彦 小林正樹 鈴木嘉茂

加藤国之 橋本敏夫 成沢達郎 新谷博一

疫学調査によれば, 虚血性心疾患に高尿酸血症が高頻度 に存在するとの報告があるが，否定的見解もある，血清尿 酸值と虚血性心疾患との関連をみるために, 急性（発症後 2 力月末満）拉よび陳旧性（発症後 2 力月以上， 1 年末 満）心筋硬塞, 狭心症, 本態性高血圧患者の尿酸值につい て検討した。対象は急性硬塞群男 61 例, 女 15 例, 陳旧 性硬塞群男 38 例, 女 8 例, 㹟心症群男 33 例, 女 16 例, そのらちで硬塞に移行したもの男 5 例, 女 2 例, 本態性高 血圧群男 41 例, 女 45 例で, 対照群は入院患者男 33 例, 女 25 例である。尿酸値に影響をおよぼすと思われる疾患 の合併例や薬剤を服用している例は対象上り除外した，尿 酸値は Caraway 変法で測定し, 中間値を採用した。男女 別に各群の平均尿酸值を比較すると, 対照群に比し, 男で は急性硬塞群 $(\mathrm{P}<0.01)$, 陳旧性硬塞群 $(\mathrm{P}<0.01)$, 狭心 症群 $(\mathrm{P}<0.05)$, 高血圧群 $(\mathrm{P}<0.001)$ の尿酸値は推計学 的に有意に高いが，女では有意差は認められなかった，各 群に护ける尿酸值の分布比較では, 尿酸値が男で $7.0 \mathrm{mg} /$ $\mathrm{d} l$ 以上，女で $6.0 \mathrm{mg} / \mathrm{d} l$ 以上を高尿酸血症とすれば，男 では対照群 $21.2 \%$, 急性硬塞群 $39.3 \%$, 陳旧性硬塞群 $50.0 \%$, 狭心症群 $36.4 \%$, 高血压群 $56.1 \%$ 飞高尿酸血 症が認められ, 高尿酸血症を有するものは対照群に比して 陳旧性硬塞群 $(\mathrm{P}<0.05)$, 高血圧群 $(\mathrm{P}<0.01)$ で有意に 高率であった，女ではそれぞれ，36.0\%，53.3\%，62.5\%， $31.3 \% ， 37.8 \%$ 飞高尿酸血症が認められたが，各群の間 に有意差はなかった，女の症例が少ないため，以下はすべ て男の症例の成績である. 各群の 60 歳未満の平均尿酸値 は 60 歳以上上り高值を示し, 対照群 $(\mathrm{P}<0.05)$, 急性硬 塞群 $(\mathrm{P}<0.05)$, 㹟心症群 $(\mathrm{P}<0.01)$ では 60 藏未満と 60 歳以上との間に有意差が認められた。高血圧群では 60 歳末満, 60 歳以上ともに $7.0 \mathrm{mg} / \mathrm{d} l$ 以上を示した。急性 心筋硬塞発作前に測定しえた 9 例を, 発作前, 発作後 3 日 以内, 7 日以内, 1 力月以内, 2 力月以内之に分けて尿酸 值を検討した結果, それらの平均尿酸值には有意差はなか った. 発作前の平均尿酸值は $6.6 \mathrm{mg} / \mathrm{d} l$ で対照群よりやや 高い傾向を示したが，有意差はなかった．急性心筋硬塞発 作後経時的に測定しえた 12 例の尿酸値の変動をみると,

発作後 4 日から 1 力月の間に発作前值より上昇する傾向が あるが, 各期間内（発作後 3 日以内, 7 日以内, 1 力月以内, 2 カ月以内）の平均尿酸值には有意差がなかった。狭心症 28 例と硬塞に移行した狭心症 5 例の平均尿酸値は, 前者 で $6.6 \mathrm{mg} / \mathrm{d} l$, 後者で $6.9 \mathrm{mg} / \mathrm{d} l$ でほとんど差がなかった。 急性心筋硬塞と狭心症について, 高血圧の有無に上り尿酸 值に有意差は認められなかった。今後, 症例数を増し, 尿 酸以外の他の危険因子との組合わせを考虑して検討する必
要がある.

質問 : 山上 徹〈大阪成人病センター〉

正常対照群に抢いて，60 歳以上の高路者で尿酸值が低 値を示したことの意義はどのように扣考学か。

答 : 五十嵐 寛

（1）加柃による血清尿酸値の変動については，男は女よ りその変動が少ないとも言われているが，われわれの成績 で対照群の 60 歳未満が 60 歳以上のもの上り高值を示し た点, 対照群のとり方にも問題があり, 例数が少ないこと も関係していると思う。

質問：長田洋文〈東大第 4 内科〉

1. 腎疾患を除外したとのことだが，この種の検討のと きに，腎疾患や腎機能低下例の除外の仕方がまちまちのよ らに思われる. 先生の所ではどのように処理されたか.

答: 五十嵐 寛

（2）腎疾患あるいは腎機能低下の criteria としては， PSP 15 分値 $25 \%$ 未満, Fishberg 最高比重 1.021 以下 とし, 検査の不充分の例では尿蛋白, 尿沈椬の所見より判 定し, 血清尿素窒素 $20 \mathrm{mg} / \mathrm{d} l$ 以上の例も除外した.

\section{8. 冠動脈硬化症における高尿酸血症について}

大阪府立成人病センター

小倉 浩 田中幸子 戸山靖一

前回の本学会で, 比較的年秢の若いものにみられる心筋 硬塞では, 高尿酸血症が特に多いことを報告したが，今回 は, 冠動脈硬化所見を有するものを対象として, 正常者, 心筀硬塞と比較検討した。

対象はドック入院患者の男子で，心電図に冠硬化所見の あるものは 330 名, 心電四に変化のないものは 343 名で あり, 他に心筋硬塞 90 名 (男子) についても同様の検討 を行なった。 な括高血圧症, 腎機能に異常のあるもの, 尿 酸值に影響を及ぼすと思われる薬剤を服用しているものは 除外した。

結果 : 尿酸值が $5 \mathrm{mg} / \mathrm{d} l$ 未満のものを尿酸值正常 (NUA) 群, $8 \mathrm{mg} / \mathrm{d} l$ 以上のものを高尿酸血症 (HUA) 群とすると, 冠硬化 (一) 群では, NUA 群は 46.4\% (159 名) に対し, HUA 群は 2.3\%（8名）にしかすぎない。これに対し， 冠硬化 (十) 群では, NUA 群は 33.6\% (111 名), HUA 群は 5. 8\%（19 名）であり，冠硬化（十）群に高尿酸血 症が多くみられる $(\mathrm{P}<0.025)$. 心筋硬塞では NUA 群 7. 8\%（7 名）に対し, HUA 群は 22.4\%（22 名）と, 冠 硬化 $(+)$ 群に比べても高尿酸血症が多くなる $(\mathrm{P}<0.00$ 5)。これを年代別にみてみると，50 藏以上では。冠硬化

(一) 群之冠硬化 $(+)$ 群の間汇有意差はみられない. しかし, 50 歳未満では, 冠硬化 (一) 群の NUA 群 43. $2 \%$, HUA 群 $2.1 \%$ に対し, 冠硬化 (+) 群では, NUA 群 $28.7 \%$, HUA 群 $9.6 \%$ であり, 有意差を認める。硬 
塞群についても同様の傾向がみられている.

次に各群における平均尿酸值を比較すると, 冠硬化 (一) 群 (343 例) は $5.21 \mathrm{mg} / \mathrm{d} l$, 冠硬化 (十) 群 (330 例) は $5.56 \mathrm{mg} / \mathrm{d} l$ であり, 冠硬化（十）群が有意に高い. 硬塞 群はさらに高くなり，6.85mg/d $l$ と冠硬化 $(+)$ 群に比べ てもな扮有意に高い $(\mathrm{P}<0.005)$. これを年代別にみると, 50 歳未満では, 冠硬化 (一) 群の平均尿酸值は $5.26 \mathrm{mg} /$ $\mathrm{d} l$ であるのに対し, 冠硬化 (十) 群では $5.75 \mathrm{mg} / \mathrm{d} l$ と有 意差を認める。しかし 50 歳以上のものでは両群の間に有 意差は認めない，硬塞群においても 50 歳未満の平均尿酸 值は $7.93 \mathrm{mg} / \mathrm{d} l$ とすば忆高くなっている.

以上のことから比較的年龄の若い男子の冠動脈硬化症で は, 高尿酸血症の合併に注意すべきで, 心筋硬塞ではさら に高尿酸血症の頻度が高く, 尿酸值も高くなることから, 高尿酸血症が冠動脈の進展に密接なる関係を有していると 考えられる。

\section{9. 虚血性心疾患における色素稀釈法による運動負荷心拍 出量と心電図変化との比較検討}

静岡県立中央病院 循環器科

鏑木恒男 池田文武 杉山知行 内田三千彦 横山正一

虚血性心疾患患者の心機能について, 心電図変化, 運動 負荷心電目のみでは充分に把握しえない場合がある。そこ で, インドシアニングリーンを使用しての色素稀釈法によ る心拍出量の測定を運動前後に行ない, 心電図变化, 運動 負荷心電図変化との関係について検討した，症例は，過去 2 年間に入院した虚血性心疾患患者の中で，心拍出量を測 定しえた急性心筋硬塞 40 例, 中間型 20 例, 労作性狭心 症 26 例で, 59 歳以下を成人群 (43 例 (男 31, 女 12)) と 60 歳以上老人群 (43 例 《男 29, 女 13》) として検討し た。年龄分布は 20 代 1 （男） 30 代 3 （男 1, 女 2 ） 40 代 17 （男 13，女 4) 50 代 22 男（16，女 6 ） 60 代 32 （男 22, 女 10） 70 代 9 （男 5, 女 4) 80 代 2 （男 2）で対照 群として 59 歳以下 13 例について検討した。 心拍出量の 测定には多方活栓装置を使用し, 同装置より时部静脈の問 に $20 \mathrm{~cm}$ のポリチューブを入れ，インドシアニングリーン $10 \mathrm{mg}(2 \mathrm{~m} l)$ をチューブ内に入れ $5 \%$ 葡萄糖で急速静注し ear peace を使用, Evma 社製, Dye-Densitogram EN-80 で测定し，心拍出量の計算は Lilienfield 及び Kovach の 計算法を使用した。運動負荷は Master double test の回 数を ear peace 装着のままで臥位で下肢の運動を行なわせ た. 心電困変化による分類は硬塞に準じて労作性狭心症, 中間型を分類した.

結果 : 59 歳以下の対照群 13 例の運動負荷前後の心拍 数, 増加率の平均はそれぞれ 4.2, 5.0 と $22.1 \%$ であった. 急性心筋硬塞群では発作後約 1 月経過した時点で測定した。
前壁中隔群では成人と老人の両群共低值のものがみられ, これらは側壁, 側壁十下壁に虚血性変化を認め, 運動後の 增加率も覀い．しかし，その後の経過を追った 3 例の中 2 例は前值増加率其比改善, 心不全傾向を示した 1 例は, あ まり改善されていない，成人群で運動前値の高い症例は, 負荷後の増加率もよかった. 前壁中隔側壁群, 側壁群でも 同様な傾向を認めた. 下壁群では, 運動前低值のものが少 なく, 運動後の増加率もよい. 心内膜下硬塞と思われる老 人群では, 広範な虚血性変化を認めた 2 例は, 運動前心拍 数も低值で増加率も低かった. 中間型では運動前值の低值 のものもみられるが, 硬塞群より高值のものが多く認め られる. 労作性狭心症では, 前壁側壁群で低值のものが認 ぬられるが前值の高いものは増加率もよい, 下壁心電図無 变化群は心拍数もよく増加率もよい, 平均值では, 老人群 よりも成人群の方が運動前值, 増加率の高い群が多かっ た. 又前壁側よりも下壁側群に高值の傾向が認められる. 運動負荷心電図との関係では, 陰性群でも, 心拍数の運動 増加率の悪いものがあり, 陽性群でも有意に上昇したもの が認められた。労作性狭心症, 中間型では負荷陰性群では 硬塞群と異なり, 増加率がよく, 中間型に比し労作性狭心 症の方がよかった. 陽性群では中間型, 労作性狭心症で低 值のものがある. その為 59 歳以下の労作性狭心症では, 陰性群の CI 増加率 $31.9 \%$ 陽性群 $14.8 \%$ であった.

\section{0. 老年者心筋硬塞の臨床的研究}

\section{一運動負荷による左心機能について一}

\section{藤沢市民病院 循環器科}

柏木政伸 大久保袁司 且井 孝 宮崎佳之

前回の老年者心筋硬塞の左室機能に関する発表につづき, 運動負荷を施行した場合の左心機能の諸指標の変化を検討 したので報告した。

観察対象は当院の CCU に収容し, 明らかに心筋硬塞と 診断しえた老年者 12 名であり全例が発症後 6 力月前後に ある症例で, 平均年秢は 66.9 歳である. 心不全の既往を 有するものは 4 例, ないものは 8 例である.なお対照とし て 60 歳以下の壮年者心筋硬塞 11 例と健康壮年 10 例に て同様の検索をした.

検査項目は左室駆出時間と前駆出時間は仰臥位で体外的 に心電図，心音図，顎動脈波を同時に記録する心機図法に より測定し，心拍出量は ${ }^{131} \mathrm{I}$ 標識ヒト血清アルブミンを急 速静注し, 心放射図より求めた。なお運動負荷は MAST. $\mathrm{ER}$ 二重二階段法により, 負荷前と直後に拈いての測定值 を比較検討した。

運動負荷前の老年者心笳硬塞の左室機能は健康老人や健 康壮年者に比し低下し, 壮年者心筋硬塞よりも低い.

MASTER 二重二階段試験前後の ET/PEP は 2.34 か ら 2.74 に増大している. この増大する値も対照に比して 
$12: 114$

少ない，負荷前の心係数の 3.1 以上と $3.0 / \mathrm{min} / \mathrm{m}^{2}$ 以 下の群で比較すと有意の差をみ, 3.1 以上の群で 2.75 よ り 3.40 に上るのが 3.0 以下の群では 2.25 上り 2.60 と 小さな変動を示寸。心不全の既往の有無で ET/PEP の変 化は既往のある群は負荷前は 1.83 で, 負荷数 2.38 と小 よく既往のない群との差は有意であった。

以上のごとく老年者心筋硬塞の左室機能は壮年者心筋硬 塞の機能より低い，心係数の小なるもの，心不全の既往を有 するものの ET/PEP は小で, 運動負荷後の変化も小さい.

質問：前田如矢〈大阪市大第 1 内科〉

心機図法による STI は種々の因子が影響する可能性が あるが，演者は群間比較で老年例に有意差があったといら 成績を示された. msec. といらこまかい単位をとりあげる 場合負荷量が問題になる。この点 2 階段法は, 高秢者では 実際上必らずしも規定量が負荷されていないこともあり得 る. treadmill または ergometer に上る負荷が妥当と思ら が如何.

答 : 柏木政伸

運動負荷の方法にはいろ問題もあろらが，老人でも Ma. ster テストは正確に指示どおりの回数を施行できる.

\section{1. 虚血性心疾患患者における自転車エルゴメーター負荷} 試験 ーインピーダンス法による心拍出量を中心とし $\tau-$

昭和大 第 3 内科

林 正博 新村与平 切士博文 小林正樹 後藤勝博 長谷川武志 藤田良範 橋本敏夫 成沢達郎 新谷博一

Minnesota Impedance Cardiograph (M. I. C.) とよる心 拍出量測定が色素稀釈法, 電磁流量計による值とかなりょ い相関を認めたので，運動負荷試験に応用し検討を加えた。

対照は正常 7 例, 心筋硬塞 16 例, 心筋硬塞を除く冠 疾患 7 例である。方法はゴダルト社製 bicycle-ergometer で最初に $50 \mathrm{~W} / \mathrm{sec} \cdot 5$ 分間の負荷を行ない，完了例には $75 \mathrm{~W} / \mathrm{sec} \cdot 5$ 分間の負荷を行ない, 途中で中止した例には $25 \mathrm{~W} / \mathrm{sec} \cdot 5$ 分間の負荷を行なった。 心拍出量は, 安静時, 運動終了直後から 1 分每に 5 分まで, 7 分, 10 分, 15 分 の計 10 回測定した. さらに Scholander ガス分析器を用 、R.M.R., Physical fitness index, $\mathrm{O}_{2}$-debt, 酸素脈, 呼吸効率等を求めた。有線テレメーター心電計で心電図, 心拍数の変動を観察した。負荷の中止基準は心電図と自覚

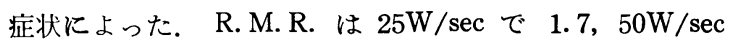
で $2.3 \sim 2.7,75 \mathrm{~W} / \mathrm{sec}$ で $3.4 \sim 3.9$ であった. 一部少数 例について実施した M. I. C. 法と色素稀釈法との同時測 定では, 運動負荷による变化もほば平行した動きを示し た.しかし色素稀釈法では運動直後の測定が遅れ, M. I. C. 法では運動直後より頻回に測定できる点は有利であった。
12巻 2 号 (1975: 3)

1 回拍出係数 (S. I. ) を安静時に対する増加率でみると, 負荷直後の增加率は酸素脈と $50 \mathrm{~W} / \mathrm{sec}$ で相関 $(\mathrm{r}=0.59)$ を認めたが， $75 \mathrm{~W} / \mathrm{sec}$ では相関は認められなかった。こ れは中止例が約 $1 / 4$ を占めたためとも考兄られる。係数 (C. I. ) の安静時に対する負荷直後の增加率は, 呼吸効率 と $75 \mathrm{~W} / \mathrm{sec}$ で負の相関 $(\mathrm{r}=-0.61)$ を認めた. C. I., S. .I の負荷直後の増加率之他の心機能を表す諸指標 (P.F. I., $\mathrm{O}_{2}$-debt, 負荷後 3 分間心拍数, との間には相関は認め られなかった．C.I.の負街直後増加率は，50W/sec で正 常者 1.5 倍, 心筋硬塞, 冠疾患約 2.4 倍と, いずれも心 筋硬塞・冠疾患で増加率が高く, 有意差を認めた. S.I.で も直後の増加率は $50 \mathrm{~W} / \mathrm{sec}$ で正常者 1.2 倍, 心筋硬塞, 冠疾患約 1.4 倍, $75 \mathrm{~W} / \mathrm{sec}$ では正常者 1.3 倍, 心笳硬 塞, 冠疾患 1.6 倍と, 有意差を認めた. 正常者に比べ筇 硬塞, 冠疾患では P.F.I., 負荷後 3 分間の心拍数, $\mathrm{O}_{2}$ debt, 負荷中最大心拍数, 酸素脈, 心電図変化, 自覚症な ぞいずれも悪い值を示した. S. I., C. I. の運動直後の增加 率は, $50 \mathrm{~W} / \mathrm{sec}, 75 \mathrm{~W} / \mathrm{sec}$ 共に前壁硬塞の方が下壁硬塞よ り高値を示した。しかし他の諸指標と此較すると，前壁硬 塞と下壁硬塞との間に差は認め難い，負荷量を増加させた 場合, 心電図変化出現例では S. I. の負荷直後の増加率が 減少し, 心電図変化が出現しない例では増加する傾向を認 めた。

質問 : 前田如矢〈大阪市大第 1 内科〉

インピーダンス・カルジオは記録時に呼吸停止が必要条 件となるが，運動直後は呼吸停止がやりにくく，また曲線 自体が動摇するので計測が困難である。その点について実 際上どの様な配虑をされたか, 計測は何心拍の平均を採用 されたか。

答: 林 正博

運動負荷直後は $3 \sim 6$ 秒後であり Impedance 法は $3 \sim$ 5 拍あれば測定できるため, 呼吸停止は問題なかった。

質問 : 石瀬昌三〈金沢大第 2 内科〉

色素稀釈法の方法を問う。

答: 林 正博

イヤーピース法で行った.

\section{2. 運動負荷による血行動態の検討} 一加齢の影響について一

金沢大 第 2 内科

石瀬昌三 森 清男 㩙峨 孝 斎木茂樹 升谷一宏 川崎 英 舟津敏朗 元田 憲 竹田亮祐

金沢医大 内科

竹越裹 村上暎二

加㱓による心機能の变化を運動負荷時血行動態面から検 討した，対象は金沢大学第 2 内科入院，外来患者のらち循 環系に異常のない者 63 名である. 方法, 被検者を仰臥位 
にてェルゴメーターを使用こ体重 $1 \mathrm{~kg}$ 当り $1 \mathrm{~W} 6$ 分間の 運動負荷を施行した，負荷前，負荷中 6 分目に，血圧，心 拍数，および色素稀釈法により心拍出量を測定した，次に， 若年者 8 名 (平均 25.6 歳), 高年者 6 名 (平均 53.4 歳), に高度の運動負荷での検討を行なった，すなわち，体重 1 $\mathrm{kg}$ 当り $1,2,3 \mathrm{~W}$ をれぞれ，6分，4分，4分間施行 し，心拍出量はそれぞれの負荷レベルで開始後 2 分目， 1 $\mathrm{W}$ 負荷は 6 分目, $2,3 \mathrm{~W}$ 負荷は 4 分目に測定した。同時 飞 30 秒間隔で上腕動脈圧波型, 心電目, 心音図, 頸動脈波 を毎秒 $100 \mathrm{mmsec}$ のペーパースピードで記録し心機㘡学 的分析を行なった。結果, $1 \mathrm{~W}$ 負荷で 20 歳代から 60 歳 代まで 10 代別に検討した。 心拍数, 血圧は負荷後, 有意 に上昇するが各年代で增加量に有意な差はなく，心拍出量 は, 安静時值は, 加齡とともに下降するが, 負荷後の增加 量は各年代で比較するとほぼ同様の増加量であり有意差は ない. 1 回拍出量は若年群で, やや大きい傾向にあるがこれ も有意差はない，全末梢血管抵抗は，安静的高値を示す高 年群で減少量が大きい傾向にある。 $1,2,3 \mathrm{~W}$ 負荷では, 心拍数，血圧は負荷レベルが上るにつれ，增加する．心拍 数は若年群之高年群間飞差はないが, 血圧は $3 \mathrm{~W}$ 負荷で高 年者群で有意に上昇する. 心拍出量は, 負荷量が増加する に従い若年者群では高年者群に比べ高値となり $3 \mathrm{~W}$ 負荷で は有意の美が認められた。 1 回拍出量の変化は, $1 \mathrm{~W}$ 負荷 では両群とも增加するが， $2 \mathrm{~W} ， 3 \mathrm{~W}$ 負荷ではほとんど増 加しない，両群間には有意の差は認められない，全末梢血 王抵抗は負荷レベルが上昇するに従い減少するが，高年者 群では血圧の上昇が強く， $2 \mathrm{~W} ， 3 \mathrm{~W}$ レベルで若年者群に 比べ有意に高い，また，同時記録した心電図，心音医頸動 脈波から心機図学的解析を行った，負荷レベルが増加する に従い, 心拍数上昇, $\theta$-II, LUET は減少の度合が大き くなる.この変化は両群で同様の傾向にあり有意な差は認 めない. P.E.P. は負荷レベルが増加するに従い減少し, LUET/PEP は増加する。これも両群で同様の傾向にあり 有意差は認めない。

考案: 安静時心拍出量は, 加齢之ともに減少し, 高年者 は若年者に比べ有意に小である。しかし, 軽度の負荷レべ ルではその増加量に有意差はなく， $3 \mathrm{~W}$ 負荷で有意に高年 者群の増加量が若年者群より少ない結果を得た。しかし虚 血性心疾患群で見られる様な変化, 即ち, 一回拍出量の減 少, PEP の減少の度合の低下, LUET/PEP の增合の度合 の低下などの所見は得られなかった。この点を考慮すると 心予備能自体には若年者群と比較して大きな障害はないも のと考えられ，高度の負荷レベルでの心拍出量の増加量の 低下はむしろ，末梢レベルでの酸素需給関係にに起因する と考学られ、これらの点については今後の検討に待ちた い.

\section{3. 狭心症の運動耐容量に関する研究 I.}

東医歯大 第 2 内科

小関 迪 新富芳明 谷口興一

労作性狭心症の運動負荷に打いて臨床的立場からみれ ば，狭心発作の発現は breaking point と考觉ることがで きる，狭心発作発現までの仕事量すなわち運動耐容量は狭 心症患者の治療や臨床経過を追跡するための重要な指標と なりらる. ergometer を用いた定量運動負荷に㧊いて 5 分 ごとに 10 watt ずつ増量していく階段的恒常負荷漸增法 を実施すれば, 負荷量は時間の関数 $L_{t}=f(t)=L_{0}+k t\left(L_{0}\right.$ ; 初回負荷量, $k$; 定数) とみなすことができ，運動耐容 量は胸痛発現時 $t_{p}$ までの積分 $W_{p}=\int_{0}^{t_{p}} f(t) d t=L_{0} t_{p}+\frac{k}{2}$ $t_{p}{ }^{2}$ で求めた。 今回は一定期間, 一定の笡密な条件設定の 下に繰り返し負荷を実施し, その平均 $W_{p}=\frac{1}{n} \Sigma W_{p i}=\frac{1}{n}$ $\Sigma f\left(t_{p}\right) i$ をもって各症例の運動耐容量とした。 この運動耐 容量の臨床的有用性を検討するため, 狭心症の臨床指標と して広く用いられている循環諸量との関係を検討した。

胸痛発現時の血圧と運動耐容量との関係には, 一定の傾 向はみられず, また安静時から発作発現までの血圧変化 $\triangle$ Pについても，相関係数 0.4 で相関を認めなかった。し かしながら心拍数との関係は比間的良い相関が認められ た. すなわち, 胸痛発現時の心拍数 $\mathrm{HR}_{\mathrm{pain}}$ 之運動耐容量 $W_{p}$ との間には, 回㷌式 $y=64.3+0.0017 x(r=0.66)$ で正 の相関を認めた。 Sarnoff らの狭心発作時の Time-Tension Index $\left(\mathrm{TTI}_{\mathrm{pain}}\right) \quad(y$ 軸） と耐容量 $(x$ 軸）との関 係は, $y=(38+0.07 x) \times 10^{2}$ 相関係数 0.51 , また Robin son らの Rate-Pressure product と運動耐容量との関係 は, $y=(97+0.34 x) \times 10^{2}$ 相関係数は 0.58 であった。胸 痛消失時間と耐容量との間には一定の相関を認めなかった。

階段的負荷漸増法による運動負荷では，負荷量は時間の 関数とみなすことができ，運動耐容量は胸痛発現にいたる 作業結果の総和としてあらわせる．循環システムにおける 心臓の調節機能は homeometric および heterometric autoregulation と心拍数により行なわれ，なかでも酸素消費 量や仕事量に相関する心拍数の役割は大きいといわれてい るが今回の成績に扎いても運動耐容量との相関が最も大で あった。 RPP， TTI はいずれも酸素消費量に相関する指 標とされており, 運動耐容量とも一応の相関を認めたが, 心拍数に比べてやや低い相関であった。

\section{4. 運動負荷心電図 $\mathrm{T}$ 波变化に及ぼす加粹の影響について} 東大 第 2 内科

村上正博 春見建一 真島三郎 下村克朗 松尾博司 加藤亮子 村尾 覚

運動負荷試験の諎パラメータ值と加齢との関係を検討し た. 


\section{$12: 116$}

日本老年医学会雑誌

対象拈よび方法：東大第 2 内科入院，外来の非心疾患患 者および某会社の健常社員 171 人で心電図正常, 血圧值 159/94 以下のものである。年秢により（I ）39 歳以下（男 31 人, 女 17 人, 平均年龄, 男 30.2 歳, 女 27.9 歳) （II） $40 \sim 55$ 歳（男 44 人, 女 32 人, 平均年㱓, 男 47.1 歳, 女 46.2 歳) (III) 56 歳以上（男 30 人, 女 17 人, 平均年秢, 男 63.2 歳, 女 61.3 歳）に分けた。記録紙速 度 $100 \mathrm{~mm}$ /秒の Frank 誘導 3 軸スカラー心電図上, QRSの 起始部から $100 \mathrm{msec}$. 部位より $40 \mathrm{msec}$. 毎に各瞬時Tベク トルを $\sqrt{\mathrm{T}_{\mathrm{x}}{ }^{2}+\mathrm{T}_{\mathrm{Y}}{ }^{2}+\mathrm{T}_{\mathrm{Z}}{ }^{2}}$ として算出しその最大值を空間最 大Tベクトル $\left(\mathrm{T}_{\max }\right.$. ) として, 運動前後におけるその差 $(\triangle \mathrm{T})$ をもとめた，対象ではすべて運動により $0.1 \mathrm{mV}$ 以 上の ST 偏位をみとめず, また運動後のT環の変形をみと めない, カフ法により収縮期血圧を, 頸動脈波, 心音図上 り左室駆出時間 (ET), 前駆出時間 (PEP) を運動前後に 扣いて測定した。運動は自転車エルゴメーター法により行 ない, 男性では $300 \mathrm{KPM} /$ 分, 3 分 $+600 \mathrm{KPM} /$ 分, 3 分, 女 性では $300 \mathrm{KPM} /$ 分, 3 分 $+450 \mathrm{KPM} /$ 分, 3 分間行った。 56 歳以上の女性群では $300 \mathrm{KPM} /$ 分, 3 分間で中止した。 結果: (1) 安静時 $\mathrm{T}_{\max .}$. の大きさは, 男女共, I 群>II 群>III群の順であった。(2) $\triangle \mathrm{T}$ は. I, II 群では。運動
12 巻 2 号 (1975: 3$)$

中, (一)となり, 運動終了直後から回復の傾向に向った. II群では, 運動中, $(+)$ となり, 運動後は更にその程度が 増し, 運動後 1 分で最大となった。（3）運動による心拍数 の変化は, 男性上り女性の方が強い傾向があるが, 各年代 群間では有意の差をみとめなかった。 $\triangle \mathrm{T} は$ 運動直後の心 拍数の増加程度とな関俰なく I 群では（一）に，III群では （+）となるものが多かった（4）運動直後の収縮期血圧は, 男女共, III群>II 群> I 群の順であり, $\triangle \mathrm{T}$ は血圧增加の 程度が少いものでは (一) に, 著明なものでは $(+)$ となっ た.（5）安静時の ET は I, III群間において著明な差をみ とめなかったが, 運動直後の ET はI 群に比し, III群で は, 短縮の程度が少かった. (6) PEP は, 安静時, 運動直 後共 I, 倓群間に差をみとめなかった。

考案拉よび結語：運動負荷心電図T波に及ぼす各種因子 の中, $\mathrm{T}_{\max }$ 減少 $(\Delta \mathrm{T}(-))$ 飞働く主な因子は心拍数増加 であり, 若年者に抢ける運動による $\triangle \mathrm{T}($ ( ) にも心拍数 因子が主に関与していることが推定される. 高年者では, 若年者に比し運動に上る収縮期血圧の上昇が著明であり, また左室駆出時間の短縮程度の低下があり, これら血行動 態変化の反応の差が高年者に打ける運動による $\mathrm{T}_{\max }$.の 増加（ $\triangle \mathrm{T}(+))$ に関与していることが推定される。 